RUBENS DOS SANTOS ROSA

\title{
AVALIAÇÃO MORFOLÓGICA DO COLÁGENO APÓS AQUECIMENTO INDUZIDO IN VIVO
}

Dissertação apresentada ao Programa de PósGraduação Interunidades em Bioengenharia - Escola de Engenharia de São Carlos / Faculdade de Medicina de Ribeirão Preto / Instituto de Química de São Carlos da Universidade de São Paulo, como parte dos requisitos para a obtenção do título de Mestre em Bioengenharia.

Orientador: Profa. Dr. Ana Maria de Guzzi Plepis 



\section{DEDICATÓRIA}

“As grandes coisas não se constroem baseadas em impulsos, mas como a soma de pequenos passos que se unem”.

Vincent Van Gogh.

Aos meus pais, Rubens e Aglacir, que além de terem me dado à vida, me deram o amor, compreensão e dedicação, para que eu chegasse até aqui. Pai, obrigado, pelo apoio nas horas certas. Mãe por tantas vezes que ficastes de joelhos sobrepostos ao chão rezando por mim. O meu muito obrigado! 


\title{
AGRADECIMENTO ESPECIAL
}

\author{
À professora e orientadora, Dr. Ana Maria de Guzzi Plepis, “a vida é como uma \\ arca imensa, cheia de possibilidades." (Amado Nervo). Quando estava perdendo a \\ esperança, você apareceu como um raio de luz renascendo em um novo amanhecer. \\ Obrigado pela oportunidade, pela paciência, pela amizade, confiança e por ter acreditado \\ em mim.
}




\section{AGRADECIMENTOS}

À professora Ana Maria Pires Soubhia, pela paciência, disponibilidade, amizade, carinho e todo apoio na minha trajetória.

Ao professor e grande amigo, Fábio Camilo, companheiro desde o início desta trajetória, incentivou para que eu fosse adiante. Obrigado Fabião!

Ao professor, Nivaldo Parizotto, em ter disponibilizado o seu tempo e ter me orientado nos momentos em que precisei. Obrigado!

Ao professor, Mário Jefferson, pela força, incentivo, e por ter despertado em mim um grande interesse pelas pesquisas deste trabalho.

Ao coordenador do Programa de Pós-Graduação Interunidades em Bioengenharia, José Carlos Pereira, pelo auxílio na conclusão deste trabalho.

À Dr. Virgínia, que me acompanhou e participou na construção e finalização deste trabalho.

Ao professor Orivaldo Lopes da Silva, pelos bons papos agradáveis nos momentos de folga e pela amizade.

Ao grande Nelson, pelos momentos descontraídos e agradáveis, valeu Nelsão. 
Aos colaboradores do laboratório da UNESP - Araçatuba - SP, Marcelinho, Cida, Luzia, Elaine e Bruno, pelo desenvolvimento, execução, carinho e receptividade que vocês me receberam.

Ao Oscar Peitl Filho do Laboratório de Materias e Vidros - LAMAV - UFSCar, por ter cedido o espaço e tempo para que eu pudesse realizar as minhas análises de birrefringência.

Ao pessoal do grupo de Bioquímica e Biomateriais, Thelma, Fabiana e Ézer por serem pessoas formidáveis, e terem me dado a maior força nos resultados do trabalho.

À Janete, pela competência e disposição em sempre me auxiliar.

Ao meu tio João e minha querida tia Aglamir, por terem acreditado em meus projetos de vida e por estarem ao meu lado sempre que precisei.

Ao meu primo Bruno e sua esposa Márcia, que apesar de estarem distantes, sei que sempre torceram por mim para que alcançasse os meus desejos.

As minhas queridas sobrinhas, Giúlia e Pietra, a felicidade de ter um olhar tão puro e sincero, regozija a minha alma, dando força para lutar pelos os meus sonhos.

Às minhas avós Virginia e Maria Rosa pelos bons momentos vividos perto de vocês (in memoriam). 
À Kelen pelo carinho, força, amor, compreensão, companhia e por ter acreditado em mim desde o início, e que sempre torceu pelo meu sucesso nesta minha luta pelos meus ideais.

Aos meus amigos de sala de aula, Ruberval, Humberto, Fernando (Carioca) Eugênia (La Hermana) e Elton e pela grande amizade que vocês me proporcionaram.

Aos meus amigos de Araçatuba, José Otávio, Sílvio, José Alberto, Fernando Carranza, Fernando Bacelar, Fernando Rodrigues, Luís Fernando e Marcelo que sempre me ajudaram de alguma forma.

Aos meus grandes amigos de profissão Julio César (BILAC), Paulinho (Guararapes), Júlio César Testa e Robson (Gapinha) pela grande amizade, que tenho por vocês.

E acima de tudo à Deus por todas os momentos difíceis, fáceis, triste e alegres $e$ as experiências vividos não só neste trabalho, mas em todos os momentos da minha vida. 


\section{RESUMO}

Rosa, R. S. (2007). Avaliação morfológica do colágeno após aquecimento induzido in vivo. Dissertação (Mestrado) - Escola de Engenharia de São Carlos, Faculdade de Medicina de Ribeirão Preto e Instituto de Química de São Carlos , Universidade de São Paulo, São Carlos, 2007.

As terapias térmicas vêm sendo utilizadas com muita frequiência em áreas da saúde, como ortopedia, dermatologia e oftalmologia entre outras. Em média a literatura revela que na prática de tratamentos com calor os tecidos são submetidos a temperaturas que não ultrapassam os $45^{\circ} \mathrm{C}(\cong 8,5$ acima da média da temperatura corpórea normal). Este trabalho procurou verificar de fato a possível influência das variações térmicas sobre o colágeno, quanto à possibilidade de desnaturação do mesmo. Utilizou-se 48 ratos (Rattus Novergicus Albinus) da raça Wistar machos, divididos em oito grupos: grupo I Controle (sem alteração térmica), grupo II $\left(35^{\circ} \mathrm{C}\right)$, III $\left(40^{\circ} \mathrm{C}\right), \operatorname{IV}\left(42^{\circ} \mathrm{C}\right), \mathrm{V}\left(45^{\circ} \mathrm{C}\right), \mathrm{VI}\left(48^{\circ} \mathrm{C}\right)$, VII $\left(50^{\circ} \mathrm{C}\right), \mathrm{VIII}\left(55^{\circ} \mathrm{C}\right)$ (cujos membros inferiores foram submersos por 10 minutos em água aquecida com temperatura variável). Em seguida os animais do grupo controle e experimental foram sacrificados, retirando por dissecação e tenotomia os tendões calcâneos que conferidos às lâminas histológicas passaram por análise microscópica de medidas de birrefringência, análise histológica por microscopia de luz e análises por calorimetria exploratória diferencial (DSC). Os resultados mostram que existe uma diferença significativa, dos grupos I a IV, em relação aos grupos V a VII, obtidos pela média de valores de retardos ópticos (RO), após as análises de medidas de birrefringência, confirmados pela análise visual histológica e pela calorimetria exploratória diferencial, sugerindo que em temperaturas elevadas ocorre uma desnaturação da proteína colágeno.

Palavras chaves: Colágeno, Desnaturação térmica, Birrefringência 


\begin{abstract}
Rosa, R. S. (2007). Avaliação morfológica do colágeno após aquecimento induzido in vivo. Dissertação (Mestrado) - Escola de Engenharia de São Carlos, Faculdade de Medicina de Ribeirão Preto e Instituto de Química de São Carlos , Universidade de São Paulo, São Carlos, 2007.

Thermal therapies are being used in orthopedic, dermatology and ophthalmology, among other medical specialties. Literature reveals in the clinical practice of thermal therapies, $45^{\circ} \mathrm{C}$ is the temperature of choice ( $\cong 8.5$ below human body temperature). The purpose of this study was to quantify changes in the tendon of calcaneous after a range of thermal exposure, and correlate these results with tissue denaturation. It was used 48 Wistar rats (Rattus Novergicus Albinus), male They grouped as: I (Control) II $\left(35^{\circ} \mathrm{C}\right)$, III $\left(40^{\circ} \mathrm{C}\right)$, IV $\left(42^{\circ} \mathrm{C}\right), \mathrm{V}\left(45^{\circ} \mathrm{C}\right)$, $\mathrm{VI}\left(48^{\circ} \mathrm{C}\right)$, VII $\left(50^{\circ} \mathrm{C}\right)$, VIII $\left(55^{\circ} \mathrm{C}\right)$, and had their pad submerged during 10 minutes in hot water (varying from $35^{\circ}$ to $55^{\circ} \mathrm{C}$. animals were sacrificed and tendon of calcaneous were analyzed by birefringence microscopy, histology ( $\mathrm{H} \& \mathrm{E}$ and Trichromic of Masson) and differential scanning calorimetry (DSC). Results showed that there is a significant difference between groups I-IV and V-VIII. Groups I-IV not shows signals of denaturation by heat treatment. Heatings above $45^{\circ} \mathrm{C}$ resulted in thermal denaturation, decreasing o birefringence and changes in histological aspect.
\end{abstract}

Key words: Collagen, Thermal denaturation, Birefringence 


\section{LISTA DE FIGURAS}

FIGURA 1 - Hierarquia do colágeno

FIGURA 2 - Modelo de alfa-hélice da molécula de colágeno... 34

FIGURA 3 - Disposição ordenada das macromoléculas 35

FIGURA 4 - Configuração molecular e fibrilar do colágeno tipo I

FIGURA 5 - Desnaturação reversível

FIGURA 6 - Representação esquemática da luz polarizada ao atravessar o material sem birrefringência 50

FIGURA 7 - Representação esquemática da luz polarizada ao atravessar o material com birrefringência 51

FIGURA 8 - Orientação do material em análise a $45^{\circ}$ à esquerda 52

FIGURA 9 - Orientação do material em análise a $45^{\circ}$ à direita 52

FIGURA 10 - Orientação do material em análise em $0^{\circ}$ .53

FIGURA 11 - Curvas do DSC demonstrativa da região de desnaturação 57

FIGURA 12 - Banho hidrotérmico do tendão calcâneo de rato 61

FIGURA 13 - Dissecação do tendão calcâneo.

FIGURA 14 - Tenotomização do tendão calcâneo 63

FIGURA 15 - Amostra do tendão calcâneo dissecado e extirpado 63

FIGURA 16 - Micrótomo Leica 65

FIGURA 17 - Gráfico da média de valores de retardos ópticos 72

FIGURA 18 - Gráfico Box Plot das médias de birrefringência. 73

FIGURA 19 - Grupo I Controle não submetidos ao experimento 74

FIGURA 20 - Grupo II $35^{\circ} \mathrm{C}$ 74

FIGURA 21 - Grupo III $40^{\circ} \mathrm{C}$ 75 
FIGURA 22 - Grupo IV $42^{\circ} \mathrm{C}$

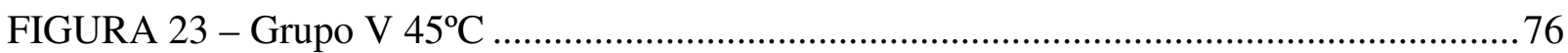

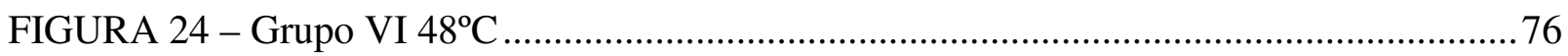

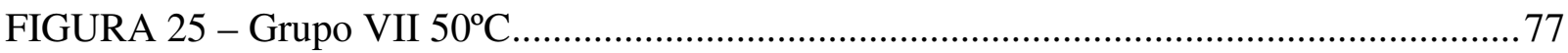

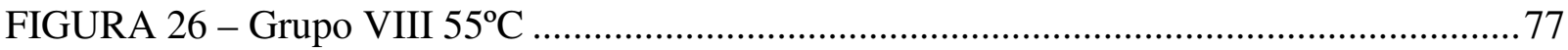

FIGURA 27 - Grupo I Controle não submetidos ao experimento com cloração (H. E)............79

FIGURA 28 - Grupo I Controle não submetidos ao experimento com cloração (T. Masson) .. 80

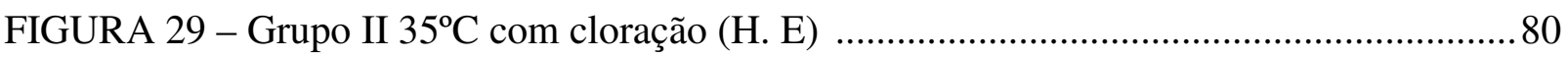

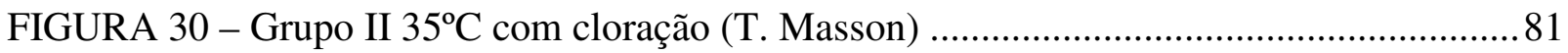

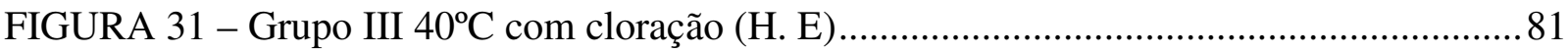

FIGURA 32 - Grupo III $40^{\circ} \mathrm{C}$ com cloração (T. Masson) ......................................................8 82

FIGURA 33 - Grupo IV $42^{\circ} \mathrm{C}$ com cloração (H. E)............................................................... 82

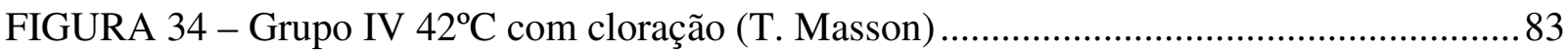

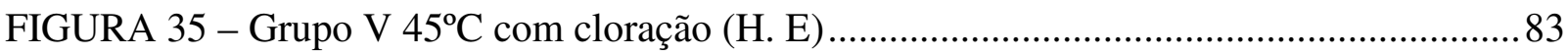

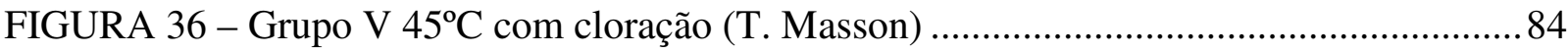

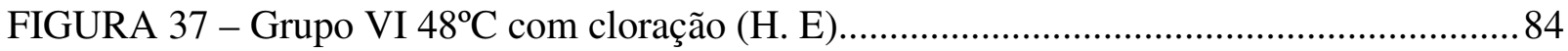

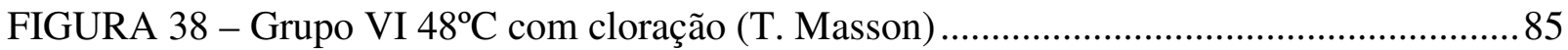

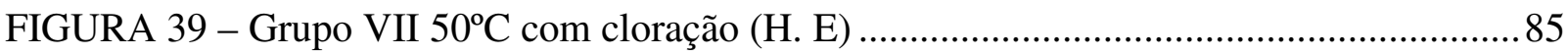

FIGURA 40 - Grupo VII $50^{\circ} \mathrm{C}$ com cloração (T. Masson) ................................................... 86

FIGURA 41 - Grupo VIII 55² com cloração (H. E) ............................................................ 86

FIGURA 42 - Grupo VIII $55^{\circ} \mathrm{C}$ com cloração (T. Masson) ….............................................. 87

FIGURA 43 - Curvas de DSC para os tendões calcâneos de ratos submetidos a diferentes temperaturas .90 


\section{LISTA DE TABELAS}

TABELA 1 - Dados observados nos oito grupos analisados e suas medidas descritivas em

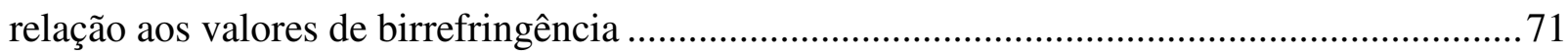




\section{SUMÁRIO}

\section{RESUMO}

\section{ABSTRACT}

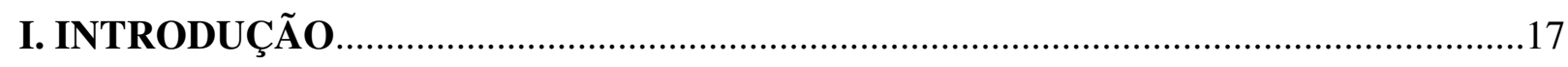

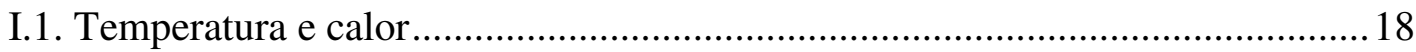

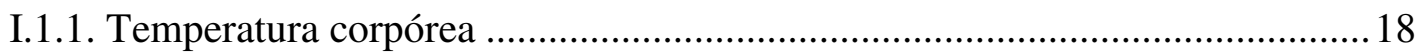

I.1.2. Efeitos sistêmicos das altas temperaturas.............................................. 19

I.1.2.1. Ação local das altas temperatura ............................................................ 19

I.1.3. Calor terapêutico (termoterapia) ...........................................................2 20

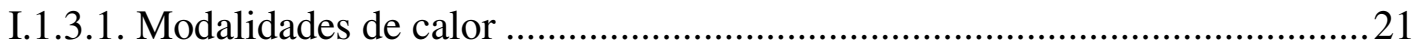

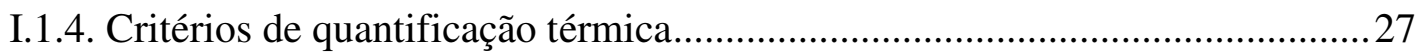

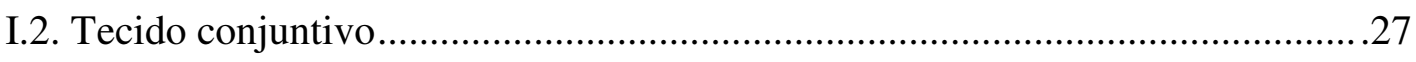

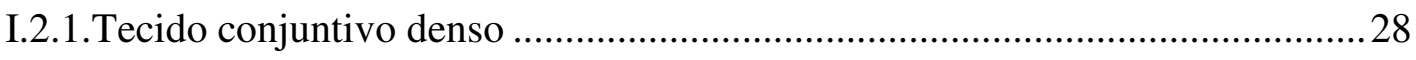

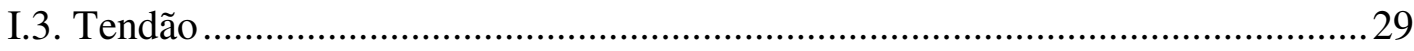

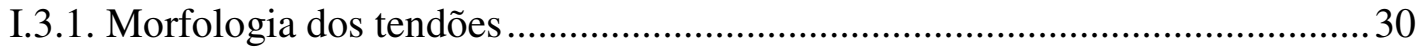

I.3.2. Ultra-estrutura do colágeno no tendão dos mamíferos...................................30

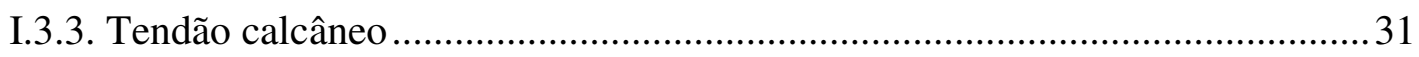

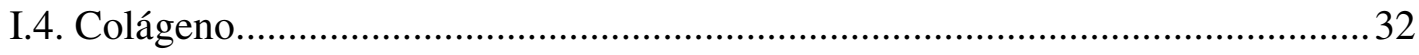

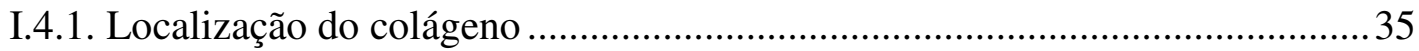

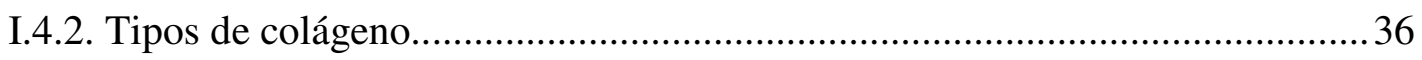

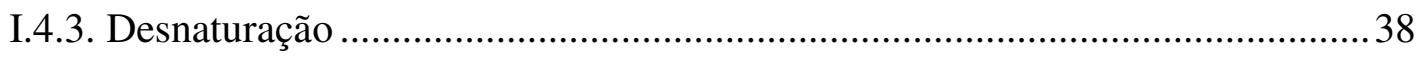


I.4.3.2. Estudo in vitro e in vivo de desnaturação... ............................................. 41

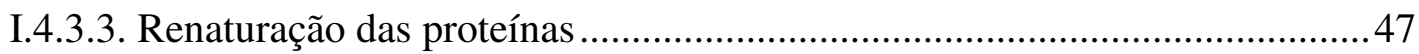

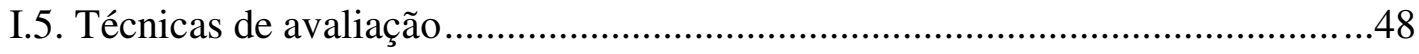

I.5.1. Microscopia de polarização................................................................. 48

I.5.2. Propriedades anisotrópicas ópticas.....................................................49

I.5.3. Birrefringência de materiais ...................................................................51

I.6. Calorimetria exploratória diferencial (DSC) ...............................................56

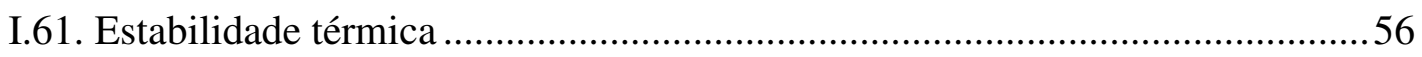

II. OBJETIVO

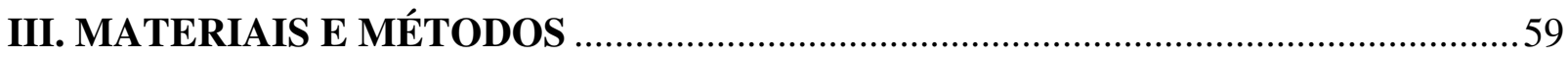

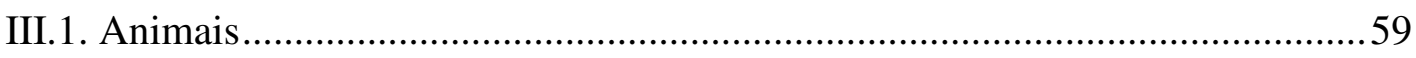

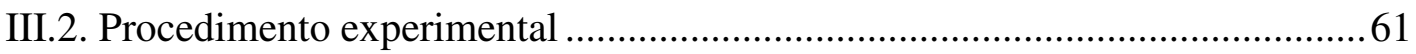

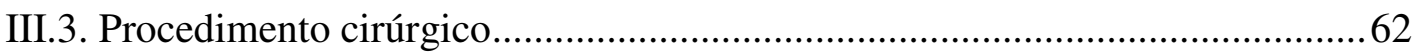

III.4. Preparação dos tecidos (tendões).Protocolo de colorações .............................64

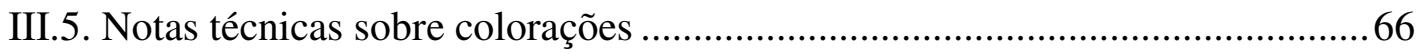

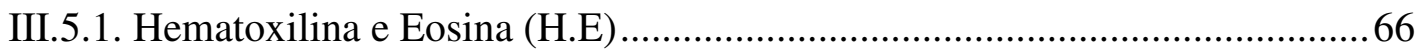

III.5.2. Tricrômicro de Masson (T. Masson) .........................................................6 66

III.6. Preparação das lâminas para análise histológica ............................................66

III.7. Preparação das lâminas para análises de microscopia de polarização..............67

III.8. Medidas de birrefringência ..............................................................6

III.9. Análises de calorimetria exploratória diferencial (DSC) .............................69

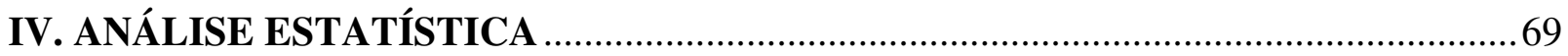

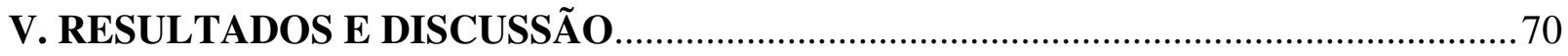


V.1. Análise macroscópica e visual dos animais durante e após os banhos

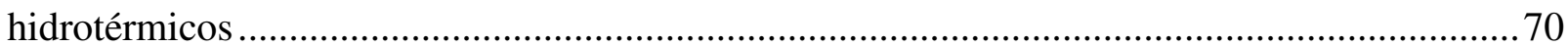

V.2. Análises de medidas de birrefringência .......................................................... 70

V.3. Análise qualitativa das medidas de birrefringência ......................................73

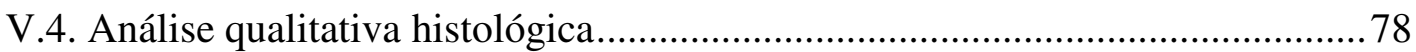

V.5. Análises da calorimetria exploratória diferencial (DCS)...............................89

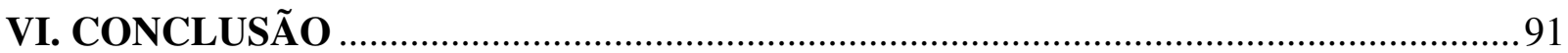

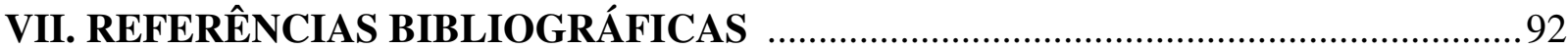

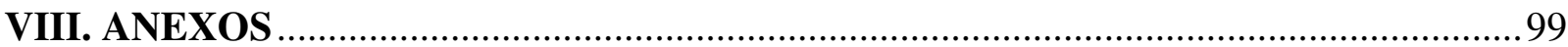




\section{LISTA DE ABREVIATURAS}

An - Analisador

ATP - Adenosina trifosfato

$\mathrm{BF}$ - Birrefringência de forma

DSC - Calorimetria Exploratória Diferencial

GAG - Glicosaminoglicano

GAGs - Glicosaminoglicanos

RO - Retardos Ópticos

Pol - Polarizador

UFSCar - Universidade Federal de São Carlos

UNESP - Universidade Estadual Paulista

$\lambda$ - Lambda - Comprimento de onda

$\mathrm{n}_{\mathrm{o}}$ - Índice de refração do meio na direção onde se propaga o raio ordinári

$\mathrm{n}_{\mathrm{e}}$ - Índice de refração do meio na direção onde se propaga o raio extraordinário 


\section{INTRODUÇÃO}

A literatura médica revela um aumento no uso clínico de aquecimento nos tecidos para tratar múltiplas doenças e traumatismos, mas os seus efeitos apresentam inúmeras controvérsias, ocorrendo variações nas técnicas utilizadas , no tempo de aplicação e na área a ser tratada. Os exemplos incluem o tratamento de má-formação artério venosa, placas ateroscleróticas, hiperplasia prostática benigna, frouxidão ligamentar, Mal de Parkinson, lesões de pele e múltiplas malignidades. Há uma necessidade de quantificar os efeitos acoplados de parâmetros clinicamente controláveis, como temperatura, ambientes químicos e de cargas mecânicas durante e imediatamente após o aquecimento.

Os diversos efeitos clínicos de temperaturas supra-fisiológicas provêm das respostas celulares, incluindo a expressão aumentada do choque de aquecimento de proteínas, morte da célula, desnaturação da proteína e coagulação do tecido. Associadas com estas alterações de aquecimentos induzidos podem ocorrer mudanças na estrutura, na função e nas propriedades do tecido. Os tecidos são compostos de várias células, proteínas, água abundante e íons, que diferem em resposta às temperaturas supra-fisiológicas, parecendo que cada um exibe comportamentos característicos similares. O foco neste trabalho é o colágeno, a proteína mais abundante no corpo humano, especificamente a fibra de colágeno do tipo I. Além disso, porque muitas terapias que tratam tecidos colagenosos estão associadas com a desnaturação, à atenção é dada aos protocolos de aquecimento que conduzem ao encolhimento e desnaturação.

O primeiro uso ortopédico de calor terapêutico de alta-temperatura foi para a administração de instabilidade de ombro (HAYASHI e MARKEL, 2001), Este tratamento é idealizado para estabilizar a articulação induzindo encolhimento do tecido (HAYASHI et al., 
1997a) e foi correlatado com a desnaturação do colágeno (KRONICK et al., 1998). O tratamento também resultou em diminuição da rigidez seguida por remodelamento biológico, mas seus efeitos em longo prazo são questionados (HECHT et al., 1999; SCHACHAR, 1991; SCHAEFER et al., 1997).

\section{I.1 Temperatura e calor}

As partículas constituintes dos corpos estão em contínuo movimento. Entende-se temperatura como sendo uma grandeza que mede o estado de agitação das partículas de um corpo, caracterizando o seu estado térmico, medida em escala padronizada com diferentes parâmetros referenciais. A escala Fahrenheit (F) considera o ponto de congelamento da água a $32^{\circ} \mathrm{C}$ e ponto de ebulição a $212^{\circ} \mathrm{C}$, enquanto que na escala em Celsius (C) o ponto de congelamento corresponde a 0 grau e o ponto de ebulição a 100 graus.

A medida de temperatura depende da precisão do termômetro, bem como da maneira como ele é utilizado. A segurança da leitura em termômetros de bulbo de mercúrio depende do tamanho de sua escala, pois termômetros pequenos dificultam a precisão de leitura.

O calor é energia térmica transferida que flui de um corpo de maior temperatura para outro de menor temperatura

\section{I.1.1. Temperatura corpórea}

Os humanos homeotérmicos devem manter sua temperatura interna dentro de uma faixa relativamente estreita de 30 a $42^{\circ} \mathrm{C}$. Temperaturas anormalmente altas ou baixas produzem padrões diferentes de danos tissulares (ROBBINS et al., 1996). 
Segundo Mountcastle (1974), os tecidos e órgãos do corpo humano funcionam melhor quando mantidos a uma temperatura relativamente constante, próxima de $37^{\circ} \mathrm{C}$. Afastamentos significantes desta faixa normal de temperaturas tissulares são associados com doenças e morte. As temperaturas dos tecidos periféricos, por exemplo, pele, músculo e tecido subcutâneo, são geralmente menores que as temperaturas viscerais e sujeitos as flutuações muito mais intensas. Temperaturas cutâneas, por exemplo, podem flutuar, sem danos, entre 20 e $40^{\circ} \mathrm{C}$. No entanto exposições prolongadas em ambientes frios ou quentes, causando temperaturas cutâneas iguais ou menores que $18^{\circ} \mathrm{C}$ e iguais ou maiores que $45^{\circ} \mathrm{C}$, estão geralmente associadas com dor e lesão tissular.

\section{I.1.2. Efeitos sistêmicos das altas temperaturas}

Se um indivíduo é submetido a temperaturas elevadas, pode haver elevação progressiva da temperatura corporal, denominando-se hipertermia. Quando a temperatura corporal atinge ou ultrapassa $40^{\circ} \mathrm{C}$, há vasodilatação periférica, abertura dos capilares, seqüestro de grande quantidade de sangue na periferia, iniciando um processo de insuficiência circulatória periférica denominado choque térmico. O estado de insuficiência circulatória se complica quando há sudorese em grande quantidade, levando a redução do volume plasmático (PITELLA FILHO et al., 1994).

\section{I.1.2.1. Ação local das altas temperaturas}

A ação local do calor pode produzir lesão denominada queimadura, cuja gravidade depende da extensão e da profundidade da lesão. 
Segundo Pitella Filho et al. (1994), o calor pode causar lesões por vários mecanismos:

- Liberação de histamina a partir dos mastócitos, o qual produz vasodilatação e o aumento da permeabilidade vascular (edema);

- Lesão direta da parede vascular, que pode aumentar o edema, produzir hemorragia e levar à trombose de pequenos vasos, com consecutiva isquemia e necrose;

- Ação direta sobre as células produzindo degeneração hidrotópica quando a elevação da temperatura vai até $52^{\circ} \mathrm{C}$. Isso se deve ao consumo de adenosina trifosfato (ATP) que acelera as reações enzimáticas sem que haja aumento proporcional do fornecimento de oxigênio (hipóxia relativa). Se a temperatura se eleva acima de $55^{\circ} \mathrm{C}$, há morte celular em decorrência da desnaturação das proteínas e subversão total das atividades metabólicas;

- Com a morte das células, há proteólise e liberação de peptídeos quimiotáticos para fagócitos que iniciam o processo de reabsorção do tecido morto e reparação cicatricial.

\section{I.1.3. Calor terapêutico (termoterapia)}

É a variação de temperatura com fins terapêuticos, isto é, dos efeitos do calor sobre os diferentes tecidos do corpo humano (LIANZA, 2001). De acordo com suas fontes, o calor é em geral, dividido em três categorias principais: 
- Ação química associada com o metabolismo celular;

- Correntes elétricas e magnéticas, como as encontradas nos dispositivos de diatermia;

- Ação mecânica (STARKEY, 2001).

\section{I.1.3.1. Modalidades de calor}

As modalidades específicas de calor terapêutico podem ser divididas corretamente em duas classes de agentes de aquecimento: calor superficial e calor profundo. Por compartilharem muitas características comuns, poderia argumentar-se que os dois grupos ocupam simplesmente posições diferentes ao longo do mesmo espectro.

A) Calor superficial: Workman (1999) afirmou que a denominação calor superficial refere-se ao aumento da temperatura da pele entre 40 a $43^{\circ} \mathrm{C}$, produzindo efeitos terapêuticos.

Lehmann et al. (1966) constataram aumento da temperatura utilizando calor superficial sobre a região do músculo quadríceps humano, com bolsa quente. $\mathrm{O}$ experimento registrou a temperatura a $1 \mathrm{~cm}$ de profundidade, em relação à pele. $\mathrm{O}$ resultado foi elevação de $1,5^{\circ} \mathrm{C}$ em 8 minutos e $3,0^{\circ} \mathrm{C}$ em 20 minutos.

Kaul e Herring (1994) verificaram aumento na temperatura nos tecidos com aplicação de calor superficial. A distribuição da temperatura nos tecidos depende da quantidade de energia convertida, profundidade e propriedades térmicas do tecido e método de aplicação. 
Abramson et al. (1967) estudaram o calor superficial úmido e seco e verificaram maior aceitação dos pacientes para o aquecimento seco em relação ao úmido. Ao compararem calor seco e úmido, em temperaturas semelhantes, o calor úmido produziu temperaturas significativamente mais elevadas na pele, região subcutânea e região intramuscular. Porém, o calor seco, em temperaturas mais elevadas, apresentou a mesma eficiência.

Porter (1998) analisou a grande incidência de tendinites, bursites e artrites em cavalos, e a dificuldade de diagnóstico e tratamento. Em relação ao tratamento recomendou a utilização de frio e faixas elásticas compressivas na fase aguda e calor superficial na fase crônica. Observou a utilização do calor superficial como uma técnica com múltiplos benefícios, porém atuando diretamente na dor. A dor está presente pelo espasmo muscular, redução da circulação e pressão da inervação periférica, causadas por alterações do tecido conectivo, assim sendo, a utilização do calor superficial pode atuar em todas essas causas, estimular o processo de reparo, como também preparando os tecidos para exercícios de mobilização. Outros autores, porém, alertam contra a utilização de calor por causa da preocupação do seu uso sobre tumor causando aumento e expansão metastática.

B) Calor profundo: Ao contrário dos agentes de aquecimento superficial, as modalidades de aquecimento profundo podem produzir temperaturas muito mais altas nos tecidos e, portanto, uma resposta mais vigorosa. Os agentes de aquecimento profundo elevam efetivamente a temperatura com ritmo bastante rápido, elevando as temperaturas teciduais até próximo dos $45^{\circ} \mathrm{C}$ e mantendo as temperaturas máximas por um período relativamente longo (LEHMANN 1982).

As formas de aquecimento estão classificadas na (Tabela 1) e dependem de propriedades térmicas e profundidade do tecido (LEHMANN, 1974).

As formas de aquecimento podem ser classificadas da seguinte maneira: 
- Radiação térmica: o calor pode ser transmitido pela radiação eletromagnética emitida de uma superfície de um corpo cuja temperatura da superfície esteja acima de zero absoluto, ocorrendo a troca de energia térmica entre objetos no espaço. (MOUNTCASTLE, 1974).

- Condução: é o mecanismo de troca de energia entre regiões de temperatura diferente, das regiões mais quentes para as mais frias, que é realizada através da colisão molecular direta. A energia transferida desse modo causa aumento nas vibrações das moléculas, que é transmitida para as moléculas adjacentes, onde se dois objetos sólidos de temperaturas diferentes entrarem em contato, o fluxo de calor é transferido do objeto mais quente para o mais frio.

- Convecção: é a troca de calor a partir de um meio, líquido ou ar, em movimento. Uma vez que há movimentação das partículas diferentemente aquecidas no interior do meio, não podendo ocorrer nos sólidos. Esse movimento de partículas acontece por diferença de densidade entre as diversas partes do fluído, causada pela diferença de temperatura.

As modificações de temperatura são resultantes de transferência de calor, e estão diretamente relacionadas à intensidade do calor, tempo de aplicação e meio térmico.

O calor uma vez transferido é difundido ao longo do tecido por movimento aleatório das moléculas, também pode ser conduzido para outras superfícies de tecido e sujeito a transmissão por fluxo de sangue local e o fluxo de fluido de irrigação. A velocidade de aumento da temperatura também desempenha um papel na determinação da extensão das respostas biológicas. Dependendo da velocidade de aumento, níveis eficazes de temperatura serão alcançados mais cedo ou mais tarde. Assim, uma modalidade que eleve rapidamente a temperatura em níveis biologicamente eficazes produzirá efeito mais pronunciado do que uma 
modalidade que eleve a temperatura tecidual mais lentamente, dado que ambas as modalidades sejam aplicadas durante o mesmo período de tempo.

Em resumo, os principais fatores que determinam o número e a intensidade das reações fisiológicas ao calor são (KOTTKE et al., 1984):

- O nível de temperatura tecidual, a faixa terapêutica aproximada que se estende de 40 a $45,5^{\circ} \mathrm{C}$;

- A duração da elevação de temperatura tecidual. A faixa terapêutica aproximada é de 3 a 30 minutos;

- A velocidade da elevação de temperatura nos tecidos;

- O tamanho da área tratada.

Algumas modalidades terapêuticas que produzem calor terapêutico e suas formas de aplicação são:

- Bolsa quente: As bolsas consistem de um gel de silicone em um invólucro de lona ou material específico. As bolsas são mergulhadas e aquecidas em banho de água de aproximadamente 71 a $79,4^{\circ} \mathrm{C}$ por 10 minutos, envolvida em uma toalha seca ou outro material apropriado e então aplicada ao corpo, onde a temperatura final da compressa deve ficar em torno de 40 a $42^{\circ} \mathrm{C}$.

Aplicação: As bolsas podem ser moldadas às superfícies irregulares e são mantidas no local por pequenos pesos ou enfaixamentos elásticos. As bolsas geralmente são aplicadas por 20 minutos (MICHLOVITZ, 1986). 
- Turbilhões: Os turbilhões são particularmente úteis no tratamento de atletas após uso de aparelhos gessado ou imobilizações prolongadas.

Aplicação: A água para o tanque tem normalmente uma temperatura entre 36,5 a $40^{\circ} \mathrm{C}$, sendo agitadas por turbinas, que misturam ar e água. A parte corporal a ser tratada é submersa, e o período habitual de tratamento é de 20 minutos.

- Banhos de contraste: Os banhos de contraste são muito comumente usados em fisioterapia e compreendem a um banho de calor e outro banho de frio que podem ser aplicados em extremidades distais.

Aplicação: São usados dois baldes, um contendo água quente (aproximadamente 38 a $44^{\circ} \mathrm{C}$ ) e outro contendo água fria (aproximadamente 10 a $18^{\circ} \mathrm{C}$ ): Inicialmente a extremidade é submersa em banho quente por 10 minutos. A seguir realiza-se uma alternância entre o banho frio por 1 minuto e o banho quente por 4 minutos, terminando no banho quente. O ciclo é repetido por 4 vezes, com tempo total de tratamento sendo em geral de 30 minutos.

- Banhos de parafina: Os banhos de parafina são misturas líquidas de cera de parafina e de óleo mineral. As partes corporais são mergulhadas no banho. Essa modalidade é seguida habitualmente por exercícios de alongamentos, pois o calor reduz a dor e a rigidez articulares. Quando aplicadas nas articulações cobertas por tecido mole subcutâneo, os banhos de parafina produzem apenas um aquecimento leve, porém quando são aplicadas nas articulações das mãos, do pé ou tornozelo, as temperaturas internas aproximam-se de $45^{\circ} \mathrm{C}$. Assim sendo, para essas articulações, os banhos de parafina são considerados como modalidade de aquecimento profundo. 
Aplicação: Uma mistura existente no comércio de cera parafina e óleo mineral são aquecidos em um banho controlado por termostato até serem alcançadas temperaturas que oscilam de 47,8 a $54,5^{\circ} \mathrm{C}$ segundo Michlovitz (1986). A mão ou pé do atleta é mergulhado no banho. A parte corporal coberta com parafina é envolta em plástico ou seis camadas de toalha por 20 minutos (LEHMANN, 1982).

- Ondas curtas: A principal ação terapêutica da diatermia de ondas curtas deriva de sua capacidade de elevar as temperaturas dos tecidos profundos, mais especificamente músculo esquelético e articulações: a diatermia de ondas curtas induz níveis terapêuticos de temperatura (40 a $45^{\circ} \mathrm{C}$ ) no tecido dos músculos esqueléticos até profundidades de 2 a $3 \mathrm{~cm}$.

Aplicação: A posologia é determinada pelos relatos do paciente. Deve ser descrita uma sensação morna agradável, mas que não seja excessivamente quente. A duração habitual do tratamento é de 20 minutos.

- Ultra-som: A onda sonora é produzida aplicando-se uma corrente elétrica alternada de alta freqüência a um cristal de quartzo natural ou sintético. Isso transforma a corrente elétrica em uma vibração mecânica. O ultra-som é um movimento ondulatório na forma de onda mecânica de alta freqüência que transmite energia térmica através da vibração das partículas no meio. Para o ultra-som realizar seus efeitos térmicos sobre os tecidos biológicos, a temperatura tecidual deve ser elevada de 1 a $4^{\circ} \mathrm{C}$, dependendo do resultado do tratamento. 
Aplicação: Em média para se alcançar a temperatura desejada é necessário de 4 a 10 minutos de aplicação ultra-sônica, mas o tempo de aplicação depende da profundidade e do tamanho da área a ser tratada.

\section{I.1.4. Critério de quantificação térmica}

Para se determinar a quantidade de aquecimento, foi criada uma escala que depende da sensação subjetiva de calor referida pelo paciente e ainda da fase em que se encontra a enfermidade, sendo baseada na escala de Schliephake (MACHADO, 1991), ou seja:

- Calor muito débil: Imediatamente abaixo do limiar de sensibilidade;

- Calor débil: Imediatamente perceptível;

- Calor médio: Sensação clara de calor;

- Calor forte: No limite da tolerância.

\section{I.2 Tecido Conjuntivo}

Segundo Junqueira e Carneiro (2004), os tecidos conjuntivos são responsáveis pelo estabelecimento e manutenção da forma do corpo. Este papel mecânico é dado por um conjunto de moléculas (matriz) que conecta e liga as células e órgãos, desta maneira dando 
suporte ao corpo. Há diversos tipos de tecidos conjuntivos, mas destacaremos mais especificamente o tecido conjuntivo denso.

\section{I.2.1. Tecido conjuntivo denso}

O tecido conjuntivo denso é caracterizado por uma relativa abundância de fibras de colágeno inextensíveis, elastina, células (fibroblastos, macrófagos e mastócitos), e substâncias de sustentação (glicosaminaglicanas, proteoglicanas, e glicoproteínas). O tecido conjuntivo denso também é conhecido como tecido conjuntivo fibroso. Baseadas no arranjo de suas fibras de colágeno, duas formas distintas de tecido conjuntivo denso são reconhecidas, a forma modelada (ou regular) e a não-modelada (ou irregular).

A) Modelado (ou regular): feixes de fibras paralelas estendem-se na direção da tensão e constituem arranjos efetivos na transmissão de trações unidirecionais. $O$ arranjo regular é característico de tendões e aponeuroses (largos tendões achatados espalhados em camadas fibrosas), que transmitem a força das contrações musculares a ossos ou cartilagens.

B) Não-modelado (ou irregular): feixes de fibras encontram-se orientados em vários planos, isto é, eles não são totalmente paralelos, consequentemente eles resistem a distensões em várias direções, sendo adequado para muitas finalidades, como: cobertura protetora fibrosa de ossos, cartilagens, elementos de suporte (cápsula fibrosa e septos ou trabéculas), além de assegurar o fluxo unidirecional no sistema circulatório (CORMACK 2003). 


\section{I.3. Tendão}

Tendões são estruturas cilíndricas, alongadas que unem os músculos aos ossos. É um exemplo típico de tecido conjuntivo denso modelado, rico em fibras de colágeno, dispostas em feixes paralelos, entre os quais existe uma pequena quantidade de substância fundamental amorfa e de fibroblastos inativos denominados fibrócitos. São orientadas longitudinalmente, transversalmente e horizontalmente com fibras de colágeno longitudinais, formando cordões espirais. Esta complexa estrutura promove ao tendão uma capacidade de equilibrar forças longitudinais, transversais, horizontais e rotacionais durante os movimentos e atividades, sua função é transmitir a força criada no músculo para os ossos tornando possível o movimento articular. No entanto, há no tendão um tecido conjuntivo frouxo que o circunda denominado paratendão. O paratendão tem a função de possibilitar o livre movimento do tendão contra os tecidos circunvizinhos. Logo abaixo do tendão uma fina bainha de tecido conjuntivo chamada de epitendão circunda o tendão. O endotendão circunda os feixes de colágeno mais internos do tendão (KHAN et al., 1999).

Os fibrócitos possuem núcleos alongados paralelos às fibras, seu citoplasma é delgado, com prolongamentos que tendem a envolver os feixes colágenos, tornando os tendões brancos e inextensíveis. Os feixes colágenos encontram-se envolvidos em conjunto por tecidos conjuntivo frouxo contendo vasos e nervos, são também providos de receptores sensitivos chamados órgãos tendinosos de Golgi.

Carlstedt (1987) relata que a maturação, o envelhecimento, o treinamento, a imobilização, o tratamento com glucocorticóides, as injeções de corticosteróides em nível local, a diabetes, a gravidez e o período pós-parto, o latirismo, a deficiência de vitamina C e os antiinflamatórios não hormonais afetam as propriedades físicas do colágeno. 


\section{I.3.1. Morfologia dos tendões}

Segundo Enoka (2000), o tendão é um tipo de tecido conjuntivo denso que contém colágeno, elastina, proteoglicanos, células (fibroblastos) e água, onde a água tipicamente ligase aos proteoglicanos pra formar um gel, promovendo a estabilidade do colágeno do tecido conjuntivo e também com alta capacidade de resistir às forças de compressão e tração que lhe são impostas, mas esta viscosidade é diminuída com a atividade.

As proteínas colágeno e elastina são sintetizadas e secretadas pelos fibroblastos, onde o colágeno tipo I aparece com maior freqüência com aproximadamente $70 \%$ a $80 \%$ do peso do tendão.

As fibrilas de colágeno são as unidades básicas de suporte de carga do tendão, que consiste em feixes de microfibrilas mantidas unidas por ligações bioquímicas (ligações transversas) entre as moléculas de colágeno, essas ligações transversas ocorrem tanto entre as fileiras de molécula de colágeno na microfibrila quanto dentro dela. O número e o estado de ligações transversas têm um efeito substancial na força do tecido conjuntivo, também sendo determinados por fatores tais como idade, sexo e nível de atividade.

\section{I.3.2. Ultra-estrutura do colágeno no tendão dos mamíferos}

O colágeno de um tendão é arranjado em feixes ondulados chamados fascículos (Figura 1). Um fascículo varia de $0,5 \AA$ a $3,0 \AA$ de diâmetro. Ele é composto de feixes de fibrilas, cada um contendo aproximadamente $100 \AA$ a $200 \AA$ de diâmetro. Cada subfibrila é composta de microfibrilas ou filamentos de feixes e cada um tem aproximadamente $35 \AA$ de 
diâmetro. Os tamanhos dos filamentos em um determinado tecido variam com a idade e outros fatores (ALTER, 2001).

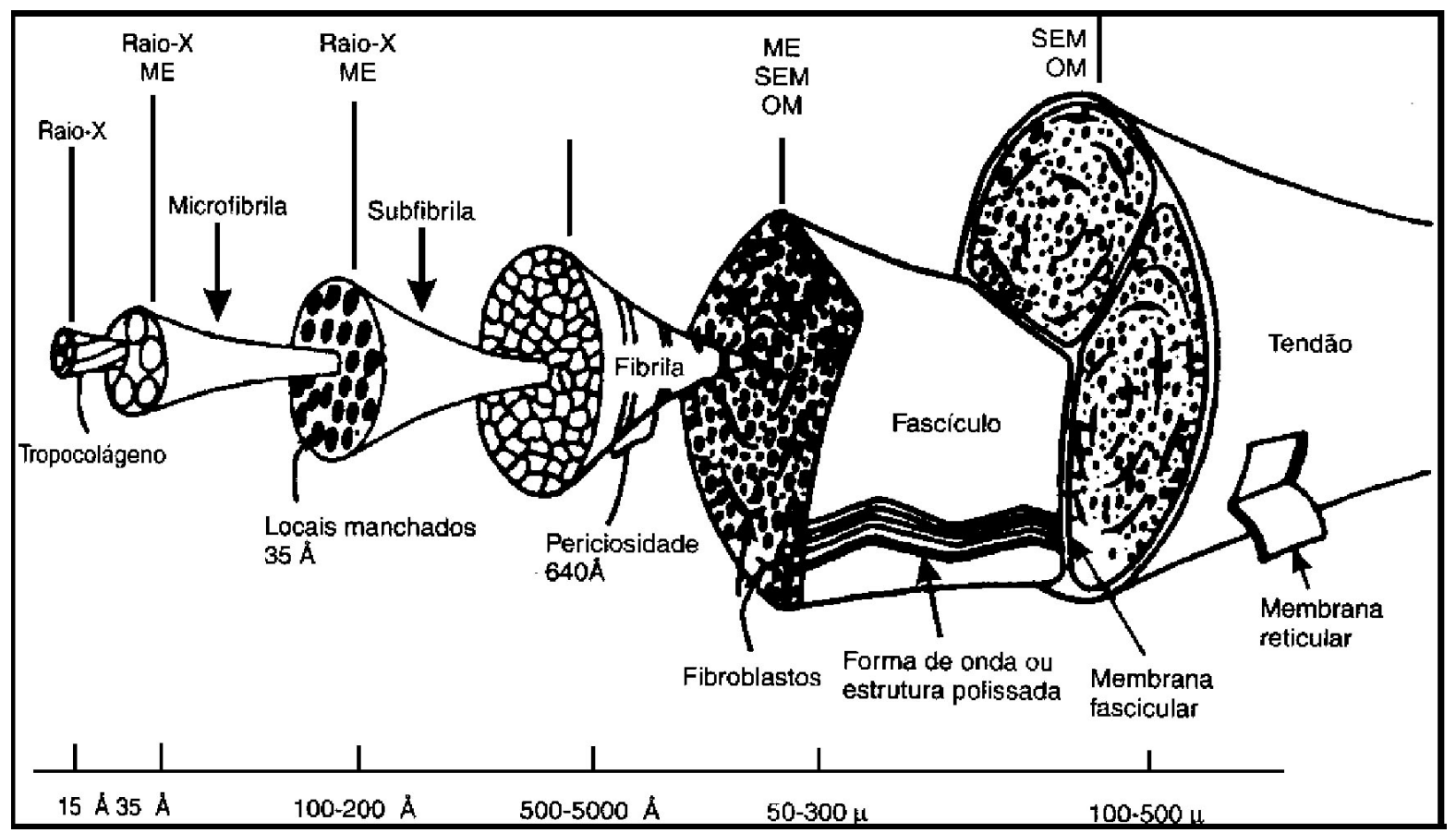

Figura 1. Hierarquia do colágeno.

Fonte: ALTER, 2001

\section{I.3.3. Tendão calcâneo}

O tendão calcâneo é o tendão comum dos músculos gastrocnêmio e sóleo, têm origem no início da continuação dos músculos gastrocnêmio e sóleo, inicialmente tem aparência larga, insere-se na parte posterior do calcâneo, onde se apresenta de uma forma mais estreita e irregular com aspecto de fibrocartilagem. É circundado pelo paratendão, que funciona como uma luva elástica que envolve o tendão e permite movimento livre contra os tecidos circundantes (ANDREWS, 2000). 
Segundo Young e Heath (2001), o tendão calcâneo são faixas inextensíveis, porém flexíveis, sendo a forma mais densa de tecido colágeno, constituídos por feixes de espessas fibras de colágeno, orientadas no eixo longitudinal do tendão com poucos fibroblastos intercalados entre feixes, onde algumas fibras de elastina também podem ser vistas entre os feixes de fibras de colágeno, entre as quais estão espalhadas fileiras de fibroblastos com núcleos alongados (ENWEMEKA, 1989a, b)

Józsa e Kannus (1987) relataram que o tendão calcâneo tem a capacidade de absorção de forças no plano sagital (flexão plantar e dorsi-flexão plantar) e no plano frontal (inversão e eversão), onde são criados estresses em diferentes lugares do tendão calcâneo.

No estado de repouso a morfologia das fibras de colágeno do tendão calcâneo apresenta-se na forma ondulada, mas ao ser estirado em $2 \%$ no seu comprimento o tendão perde a sua morfologia (PLAPLER et al., 2001).

Durante a locomoção e o suporte de peso o tendão calcâneo tem grande capacidade de resistência às forças que são requeridas, pelo fato da densidade numérica, organização e a disposição e arranjo das fibrilas do tendão, o que lhe permite uma resistência aos estiramentos e tração (ENWEMEKA et al., 1988).

\section{I.4. Colágeno}

O colágeno no corpo dos mamíferos é encontrado nos tendões, ligamentos, cápsula dos órgãos, derme, tecido conjuntivo frouxo, dentina, entre outros (NIMNI e HARKNESS, 1988). É a proteína que compõe a cerca de $30 \%$ do peso corporal do ser humano, tendo maior 
presença nos tecidos conjuntivos e atua na matriz extracelular dos animais (CULAW et al., 1999; PARIZOTTO, 1998).

São proteínas estruturais arranjadas em feixes exceto sob tensão. As fibras de colágeno só são capazes de um leve grau de extensibilidade. Elas são, contudo, muito resistentes ao estresse de tração. Portanto, elas são as principais constituintes de estruturas como ligamentos e tendões que são submetidos a uma força de tração (ALTER, 2001).

A diferença de um tipo de colágeno para o outro ocorre através de suas cadeias de polipeptídios, propriedades físicas, morfologia, distribuições nos tecidos e funções, onde todas as moléculas de colágeno são longas; constituídas de uma hélice tripla, cujas de três cadeias peptídicas chamadas de cadeia alfa (MIMNI e HARKNESS, 1988).

O colágeno tem características próprias na sua composição de aminoácidos; que consiste em uma repetição tripla, $(\mathrm{G}-\mathrm{X}-\mathrm{Y})_{\mathrm{n}}$, onde $\mathrm{G}$ é a glicina, e X e Y são freqüentemente prolina ou hidroxiprolina, sendo que a cada três aminoácidos o terceiro é sempre glicina. A prolina e hidroxiprolina aparecem em $20 \%$ dos aminoácidos da cadeia de colágeno (CULAW et al., 1999).

Células mastócitos, macrófagos e algumas células indiferenciadas originadas do tendão, epitendão e paratendão tem a capacidade de sintetizar colágeno tipo I, mas as principais células responsáveis pela síntese de colágeno tipo I são os fibroblastos (CHEN et al., 1997; JÓZSA e KANNUS, 1997).

No colágeno tipo I, o mais comum, a hélice tripla está constituída por duas cadeias $\alpha$ (alfa) iguais, denominadas $\alpha_{1}$, e uma cadeia $\alpha_{2}$ diferentes das demais em sua composição. As cadeias peptídicas se enrolam em hélice e são unidas entre si através de pontes de hidrogênio (Figura 2). Pode-se representar o colágeno tipo I pela fórmula: $\left.\left[\alpha_{1}(\mathrm{I})\right)\right]_{2} \alpha_{2}$. 
Vidal (1987a) relata que nas duas extremidades da hélice tripla estendem-se porções de cadeias peptídicas que não estão formando a hélice tripla, os telopeptídios $C$ e $N$ terminais, responsáveis pela agregação lateral das moléculas de colágeno.

A presença de prolina e hidroxiprolina mantém o arranjo em forma de corda do colágeno estável e resistente ao alongamento. Desta forma, quanto maior a concentração destes aminoácidos, maior será a resistência de alongamento das moléculas. Pelo fato de o nitrogênio da prolina ser fixo em uma estrutura de anel, sua presença dificulta a rotação fácil nas regiões em que é localizada (GRANT, PROCKOP, DARWIN, 1972; GROSS, 1961).

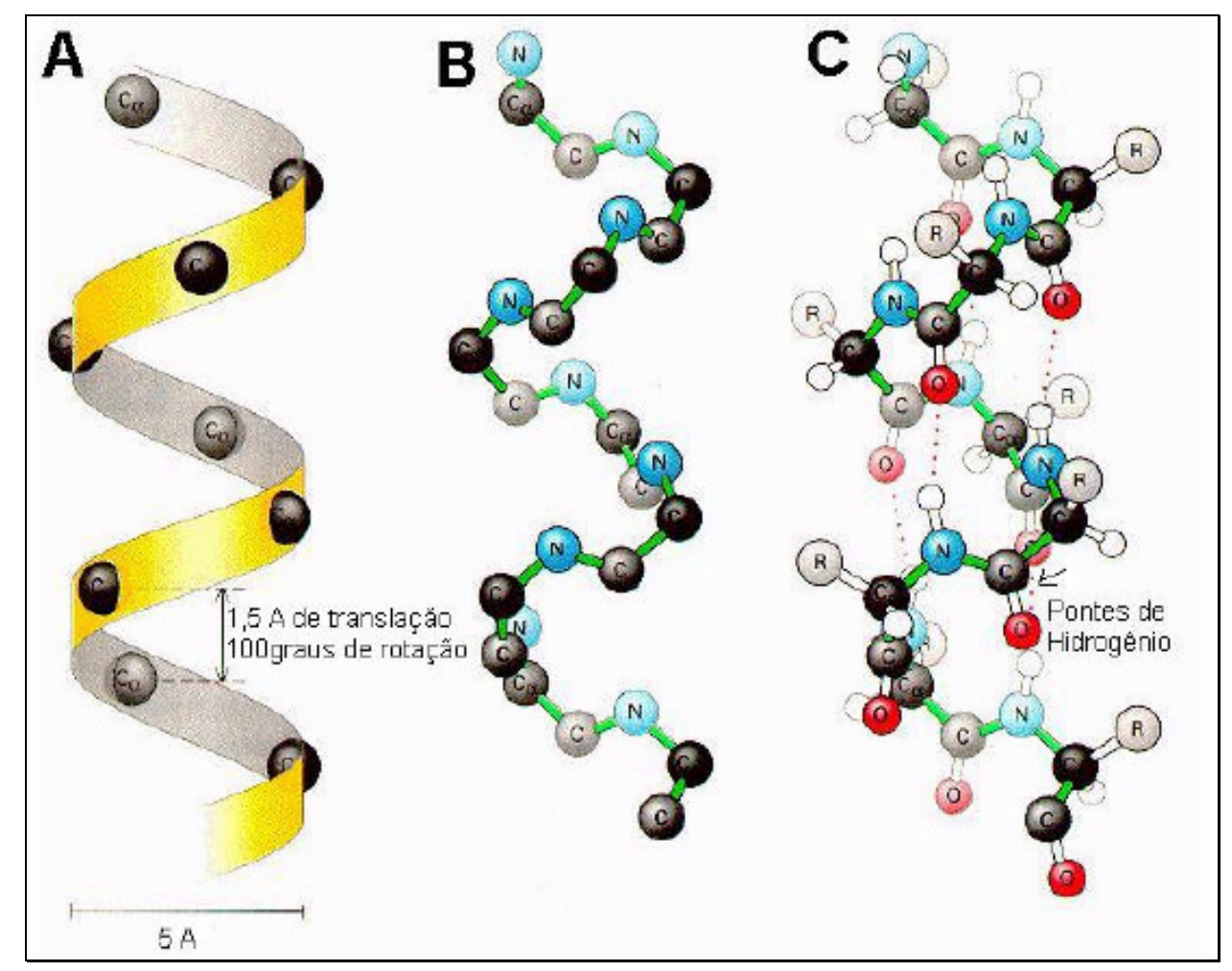

Figura 2. Modelo de uma alfa-hélice da molécula de colágeno modificado de K Okuyama. Fonte: OKUYAMA, 1981.

Segundo Tillman e Cummings (1992), quando as moléculas de colágeno se encontram secretadas no espaço intercelular, cada grupo de cinco moléculas de colágeno é compactado para formar a ordenada microfibrila; a menor unidade da organização da fibra. A 
próxima unidade da organização é a subfibrila, que agrupadas constituirão as fibrilas. Essa hierarquia reflete a alta organização da estrutura molecular do colágeno (Figura 3).

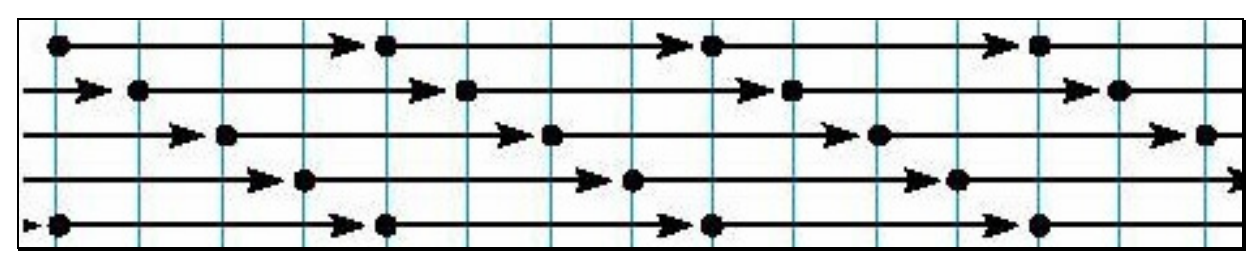

Figura 3. Disposição ordenada das macromoléculas. Fonte: CUERONET.COM, 2006.

Esta disposição ordenada das macromoléculas explica também uma propriedade física e óptica fundamental que é a birrefringência, que é um dos métodos que foram usados para distinguir os distintos tipos de colágeno (CUERONET.COM, 2006).

\section{I.4.1. Localização do colágeno}

Primeiramente o colágeno está especialmente concentrado em tecidos que suportam o peso do organismo, fundamentalmente as cartilagens e os ossos.

Secundariamente também existe colágeno concentrado em altas proporções naquelas partes do organismo que transmitem força, como os tendões e ligamentos.

Em terceiro lugar, o colágeno aparece de forma numerosa em lugares como a derme ou fáscias que são lâminas que recobrem os músculos, eles servem para proteger, ou onde é necessário um material que resista à tração ou as mudanças de volume. Finalmente, o colágeno, em uma de suas formas, constitui praticamente uma armação de microfibrilas, que sustenta a estrutura de todos os órgãos e vísceras do organismo. Ou seja, que encontramos 
pequenas fibrilas de colágeno no fígado, no baço, no pulmão, em resumo, não há nenhuma víscera que não tenha esta armação de colágeno. Por exemplo, os vasos sangüíneos que são tubos, mantêm sua forma tubular em função de que ao redor da parede tem uma trama em espiral de fibrilas de colágeno, que constitui o suporte desta estrutura tubular (CUERONET.COM, 2006).

\section{I.4.2. Tipos de colágeno}

Existe um número extenso de diferentes tipos de colágeno (RAIMOND, TUCKWELL, PLUMB, 2003), onde cada tipo é identificado por um número romano, que reflete simplesmente a ordem, na qual, os tipos de colágeno foram descobertos, mas no presente trabalho, destacará apenas os cinco primeiros tipos.

- Colágeno tipo I: Constitui $90 \%$ do total de colágeno do corpo dos mamíferos e é encontrado com maior freqüência em estruturas como tendões, ligamentos, cápsulas dos órgãos, derme, matriz para reforço do esqueleto, associado também aos minerais como ossos e dentina, entre outros tecidos especiais que devem ser fortes ou ter propriedades incomuns (NIMNI e HARKNESS, 1988). Este tipo de colágeno possui alta força tênsil com elasticidade limitada, além de boa capacidade para transmissão de forças (CULAW et al., 1999). São as fibras mais grossas de todas, fortemente birrefringentes ao microscópio de polarização. Também se caracteriza porque a molécula de tropocolágeno neste caso é constituída 
por duas cadeias que são denominadas $\alpha 1$ (I), quer dizer, duas cadeias $\alpha 1$ (I) idênticas e uma segunda cadeia que é denominada $\alpha 2$ (I), que tem uma seqüência de aminoácidos distinta. Este é um colágeno fabricado fundamentalmente pelos fibroblastos.

- Colágeno tipo II: Aparece na cartilagem e em outras estruturas, como por exemplo, o líquido que enche o globo ocular chamado humor vítreo. São fibras muito finas que não vê ou se vê com dificuldade no microscópio óptico, mas se vê com o microscópio eletrônico.

São fibras constituídas de três cadeias denominadas $\alpha 1$ (II), com três cadeias iguais, cruzadas contendo mais hidroxilisina e lisina que no colágeno ordinário de tipo I.

- Colágeno tipo III: Corresponde ao que classicamente se denomina as fibrilas de reticulina. É um colágeno que aparece com muita freqüência unido ao músculo liso e é fundamentalmente o colágeno das vísceras, embora também esteja presente em maiores quantidades na derme, principalmente ao redor dos nervos e dos vasos sanguíneos.

Do ponto de vista da composição dos polipeptídios, tem três cadeias denominadas $\alpha 1$ (III). Quer dizer, tem três cadeias iguais, com uma disposição de aminoácidos próprios onde predomina a hidroxiprolina e onde também aparece um aminoácido que não é muito comum em outros tipos de colágeno que é a cistina.

- Colágeno tipo IV e V: Aparecem especificamente localizados nas membranas basais, ou seja, são nessas estruturas que geralmente são separados os epitélios dos tecidos conjuntivos. O colágeno IV é muito 
freqüente em todas as membranas basais. $\mathrm{O}$ colágeno $\mathrm{V}$ foi descrito especificamente na membrana basal da placenta (órgão muito especial, transitório) que citamos só para dar um exemplo de como esta proteína se adapta a distintas funções biológicas que vão aparecendo ao longo da evolução das espécies (CUERONET.COM, 2006).

\section{I.4.3 Desnaturação}

Aplica-se o termo desnaturação a uma grande variedade de alterações estruturais, com diferentes efeitos sobre as proteínas individuais. A desnaturação é um processo quimicamente complexo, não sendo fácil descrever as interações entre agentes desnaturantes e proteínas, responsáveis pela ocorrência de alterações na conformação. No caso de algumas proteínas, a produção de discretas mudanças na conformação pode não destruir a atividade biológica da molécula, enquanto outras perdem sua atividade com pequenas alterações conformacionais que não são facilmente detectadas pelos métodos disponíveis (SMITH et al., 1985).

Cada proteína do corpo tem uma forma normal chamada sua conformação nativa. Este arranjo é requerido para proteína realizar sua função biológica. A desorganização da estrutura protéica, ou destruição da conformação nativa é chamada de desnaturação. Este processo geralmente envolve a quebra de ligações fracas não covalentes que mantêm a estruturas das cadeias polipeptídicas. Embora as ligações peptídicas não sejam quebradas, as estruturas secundárias e terciárias são perdidas (UCKO, 1992). 
Os mecanismos de desnaturação em geral acontecem quando as proteínas são elevadas à temperatura de 50 a $60^{\circ} \mathrm{C}$ durante certo período de tempo. Todavia, a temperatura exata que induz mudanças de conformação varia amplamente entre diferentes proteínas.

A desnaturação consiste no desenovelamento de uma estrutura nativa caracteristicamente dobrada da cadeia polipeptídica das moléculas de proteínas globulares. Quando a agitação térmica faz com que a estrutura nativa enovelada sofra um desenovelamento ou desenrolamento, passando a uma cadeia casualmente dobrada, a proteína perde sua atividade biológica. Ainda que cada tipo de proteína possua uma composição e uma seqüência fixa de aminoácidos durante a biossíntese, a sequiência de aminoácidos por si só não atribui diretamente à atividade ou função biológica específica da proteína.

Entretanto a seqüência de aminoácidos determina, em última análise, a atividade biológica da proteína, uma vez que ela determina a conformação nativa, o estado enovelado, da molécula protéica, através das interações das cadeias laterais dos aminoácidos, umas com as outras, com o solvente, e com os outros solutos presentes. Essa conclusão resultou da descoberta de que a desnaturação, ou desenovelamento, das proteínas nativas em uma forma enovelada ao acaso, biologicamente inativa, não é irreversível, como se pensou anteriormente.

\section{I.4.3.1 Desnaturação do colágeno}

Desnaturação térmica é um processo endotérmico com a qual a hélice tripla do colágeno desenrola depois de uma ativação crítica de energia ser alcançada (MILES e GHELASHVILI, 1999). A calorimetria exploratória diferencial (DSC) pode ser usado para correlatar à exposição térmica com o grau resultante de desnaturação.

Os efeitos do aquecimento do colágeno podem ser reversíveis ou irreversíveis. O aquecimento moderado pode resultar em um local desdobrado dentro da proteína. Este 
desdobramento pode ser devido à quebra de um número pequeno de ligações consecutivas de hidrogênio. O aquecimento severo resulta em uma transformação irreversível tempodependente da estrutura helicoidal tripla nativa e uma estrutura (enovelada, enrolada) mais aleatória (BRANDTS, 1969; PRIVALOV, 1982). Pensa-se que a última transformação ocorre primeiramente através da quebra de sequiências mais longas das ligações de hidrogênio que estabilizam a hélice tripla, em subconjuntos particulares ao longo da molécula, isto é, entre os resíduos $877 \mathrm{~nm}$ e $936 \mathrm{~nm}$, (Figura 4) que podem ser mais suscetíveis a quebrar as ligações consecutivas de hidrogênio (WRIGHT e HUMPHREY, 2002).

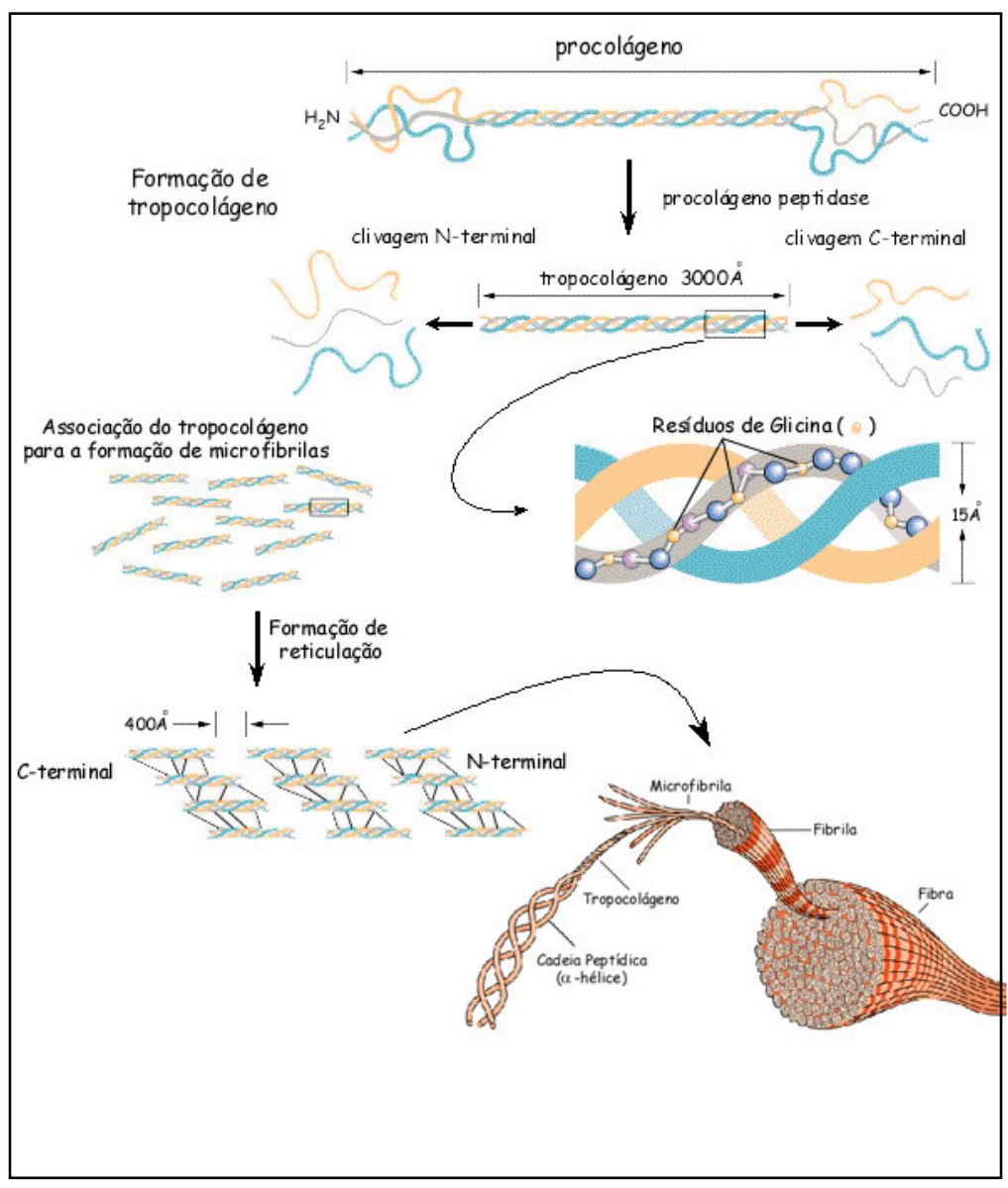

Figura 4. Configuração molecular e fibrilar do colágeno tipo I Fonte: RODRIGUES, 2006 


\section{I.4.3.2. Estudo in vitro e in vivo de desnaturação}

Em resumo, os dados biomecânicos disponíveis indicam que embora possam ser alcançadas alterações significativas no comprimento de tecidos capsulares e ligamentosos na hora do tratamento térmico in vitro e em menor extensão in vivo, o encolhimento pode não ser mantido a uma atividade física resumida. Neste momento os efeitos nas propriedades estruturais e materiais fornecem também motivo para preocupação, porque em alguns estudos a técnica parece resultar em reduções significativas em força e rigidez do tecido na fase aguda. Isto deveria também ser lembrado que estas investigações biomecânicas foram baseadas em tecidos normais, que são provavelmente para se comportar de forma bastante diferente dos tecidos achados patologicamente em articulações instáveis ou articulações sujeitadas a cirurgia prévia; a importância relativa da orientação da fibrila de colágeno e extensão ou tipo de ligações cruzadas tem que ainda ser determinada (WALLACE, HOLLINSHEAD, FRANK; 2002).

Porém, testes mecânicos imediatamente após o tratamento mostraram uma redução significativa em rigidez do tecido, até mesmo quando o tecido foi esticado novamente ao seu comprimento original.

A resposta biológica para encolhimento térmico até o momento contém poucas informações disponíveis sobre morfologia, ultra-estrutura e mudanças bioquímicas que formam a base das alterações mecânicas do tecido conjuntivo, resultante do tratamento térmico, algum discernimento sobre possíveis mecanismos envolvidos pode ser proveitoso de observações feitas depois dos danos dérmicos (WALLACE et al., 2002).

Em estudos in vitro as análises e quantificação das respostas térmicas características do tecido colagenosos são difíceis devido às diversas espécies e variação composicional entre tecidos. Passado quatro décadas, têm-se feito várias pesquisas 
experimentais com tendão, ligamento, pele, cápsula articular e espécie de tecido córneo colhido de diferentes espécies, como: boi, cachorro, rato, coelho, carneiro e humanos (AKSAN, ARNOCZKY, 2000).

Isto se estabelece quando os tecidos colagenosos são expostos em altas temperaturas na faixa de 65 a $85^{\circ} \mathrm{C}$ para muitos tipos de tecidos e espécies, eles sofrem rápida desnaturação. O efeito resultante do fenômeno molecular-microfibrilar da desnaturação do colágeno é o encolhimento do tecido. Em uma temperatura constante, o encolhimento aumenta com o aumento da exposição até alcançar além do valor constante, após o qual nenhum encolhimento adicional é observado. Este valor se altera se for alterada a temperatura de tratamento e se cargas mecânicas forem aplicadas no tecido durante o aquecimento. Altas temperaturas por grandes períodos de tempos resultam em clareamento, dano extensivo, e necrose do tecido.

Aksan e Arnoczky (2000) reportam que em experimentos de aquecimentos hidrotérmicos feitos sobre amostras de espécies obtidas de diferentes regiões de cápsulas articulares glenoumerais de cadáver para a correlação entre a máxima temperatura alcançada e a quantia de encolhimento de tecido, em exposições ao calor a $65^{\circ} \mathrm{C}$ por 10 minutos resultou em $10 \%$ de encolhimento onde $60 \%$ do encolhimento ocorreram somente depois de 1,5 minutos a $80^{\circ} \mathrm{C}$. Um experimento parecido com o uso de aquecimento de rádio-freqüência colhido de espécies de cápsulas articulares glenoumeral de carneiro demonstrou menos que $4 \%$ de encolhimento em temperaturas inferior a $65^{\circ} \mathrm{C}$, mas alcançou um valor de pico de $14 \%$ de encolhimento a $80^{\circ} \mathrm{C}$. Discrepâncias entre esses resultados podem ser devido às diferenças na composição dos tecidos (humanos e de carneiro) e o possível efeito não térmico de duas modalidades de aquecimento. A variabilidade da quantidade de encolhimento de tecidos similares de diferentes espécies sob condições idênticas de aquecimento é bem estabelecida 
na literatura. Isto também mostrou que estas variações correlacionam bem com diferenças na fisiologia da temperatura corpórea das espécies.

Outro fator é que aquecimento a laser causa desidratação local dos tecidos devido à evaporação dos fluidos no volume alvo, enquanto isto não é problema com o aquecimento hidrotérmico. A energia a laser aumenta a cicatrização por estimulação de síntese de colágeno, embora, ainda nenhum estudo tem comparado os efeitos não-termais de várias modalidades de cicatrização (AKSAN, ARNOCZKY, 2000).

Há outras diferenças entre modalidades de aquecimento. Em aquecimentos hidrotérmicos, amostras de tecidos são imersas em banhos em uma temperatura constante, e rapidamente os tecidos tornam-se equilibrados termicamente no seu interior e ao seu redor. Portanto, uma distribuição de temperatura homogênea pode ser obtida dentro do tecido. No aquecimento a laser ou rádio-freqüência, a distribuição gerada dentro do tecido é uma função da velocidade da tentativa de varredura, a distância entre o tecido alvo e a profundidade de penetração do aquecimento. A combinação desses fatores pode facilmente causar aquecimento não homogêneo. Diferenças entre histórias térmicas de regiões dentro do volume do mesmo tecido podem causar trocas significativas na ultra-estrutura e no comportamento, resultando em encolhimento não uniforme.

Alguns estudos revelaram que o aquecimento hidrotérmico e a laser causam diferenças no resultado da ultra-estrutura do tecido colagenoso, mas estas variações não têm sido atribuídas especificamente para cada efeito não térmico ou diferenças entre aplicações. Na soma, depois do aquecimento, se o tecido colagenoso é resfriado até temperatura ambiente algumas moléculas de colágeno readquirem sua estrutura hélice tripla, renaturação, isto pode ser acompanhado por uma frouxidão de $5 \%$ a $10 \%$ da quantia total do encolhimento obtido (AKSAN, ARNOCZKY, 2000). 
O efeito do estresse mecânico no encolhimento e as características de frouxidão após o aquecimento do cordão tendíneo de bovinos foi investigado por Aksan e Arnoczky (2000).

Em um estudo Chen et al. (1997) relatou o aumentou um quíntuplo na aplicação do estresse causando aproximadamente uma diminuição de $15 \%$ no valor constante final do encolhimento e demora no processo de renaturação. Os autores sugeriram que há uma equivalência tempo-temperatura-carga no aquecimento induzido do encolhimento dos tecidos colagenosos. Isto é, estas variáveis são para uma extensa troca, eles têm efeitos similares no comportamento em tecido espesso e algumas de suas mudanças afetaram o processo de encolhimento. Estas hipóteses podem ter aplicações clínicas muito importantes, em que a mesma quantia de encolhimento do tecido pode ser obtida em uma baixa temperatura, minimizando o risco excessivo da perda de rigidez e dano térmico ao redor dos tecidos.

Pesquisas feitas por Hayashi et al. (1995, 1999) em tecidos capsulares glenoumerais em cadáver sugerem que a rigidez do tecido colagenoso aquecido diminui quando propriedades viscoelásticas permanecem inalteradas. Valores de rigidez diminuíram para 90\% do normal, medidas após o aquecimento agressivo a laser. Similar à resposta do encolhimento, a diminuição em rigidez é também dosada. O elevado aquecimento, a notável perda da rigidez é preocupante porque ele pode fazer o tecido mais vulnerável para pósoperação de carga mecânica.

Estudos in vivo revelam que há somente um número limitado de estudos de efeitos in vivo de modificações térmicas em tecidos conectivos biológicos e biomecânicos (HAYASHI et al. (1997b, c), WALLACE et al. (1999), SANDUSKY et al. (1999), SCHAEFER et al. (1997). Embora muitas pesquisas concordam que após a modificação térmica e o acompanhamento de morte de células locais, modificam o tecido sofrendo uma resposta de reparo caracterizada por fibroplasia, neovascularização e formação de cicatriz 
fibrovascular. Em estudos com carneiros e coelhos, os tecidos começam a regenerar somente 7 dias após o tratamento, como evidenciado por hiperplasia e aumento da atividade fibroelástica. A vascularização na região da cicatriz e a migração de mais fibroblastos para o lugar tratado acompanham um longo termo da resposta de cicatrização do tecido. Após 1 mês, sintetizou novamente moléculas de colágeno e o pequeno diâmetro das fibras estão presentes na área de cicatrização.

Estudos têm sugerido que são necessárias 12 semanas para que uma modificação térmica ocorra, e para que o tecido retorne a força normal, embora outros estudos tenham mostrado que durante o mesmo período de tempo, os tecidos têm um aumento sensível na elasticidade Isto não é uma opinião unânime com o tempo na qual os tecidos modificados termicamente tornam normal seu material e suas propriedades biológicas (AKSAN, ARNOCZKY, 2000).

Achados clínicos revelam que os efeitos da energia a calor sobre as moléculas de colágeno têm sido bem estabelecidas, a razão para a eficácia relatada para este modo de terapia de tratamento de frouxidão excessiva de tecido colagenoso é menos evidente. Isto ainda não tem sido bem estabelecido o que é realmente responsável por um aperfeiçoamento clínico após o encolhimento térmico capsular se isto é o encolhimento inicial do tecido conectivo, com o qual aparece estirado e embora estabilize a articulação, a fibroplasia, cápsula espessa e formação de cicatriz secundária que ocorre na resposta da lesão traumática, a perda exatamente da estimulação sensorial aferente para destruição dos receptores sensoriais. (FANTON (1998), FANTON et. al (1998), THABIT (1998)).

Embora esta questão fundamental permaneça sem resposta certamente implicações clínicas são claras. O grau inicial do encolhimento do tecido e o último dano do tecido é diretamente relatado para a quantia e a taxa de energia térmica aplicada, e a quantia de encolhimento do tecido é diretamente correlacionado com a perda de enrijecimento do tecido. 
Estudos experimentais têm mostrado que imediatamente após o encolhimento térmico, tecidos conectivos demonstraram uma significativa de perda de enrijecimento. Esta perda de rigidez está relacionada com o encolhimento, ou seja, maior encolhimento resulta em maior perda de rigidez. Assim, por exemplo, estirar a frouxidão da articulação capsular ou ligamentos por indução de encolhimento térmico, torna os tecidos mais enfraquecidos e mais complacentes, o que pode trazer riscos pós-opertótios.

Boykin e Molnar (1992) reportam que a temperatura a $45^{\circ} \mathrm{C}$ é letal para muitas células. Isto sugere que após a aplicação térmica, uma porção significante do tecido encolha visivelmente e morra. Adicionalmente é possível que os tecidos adjacentes que não obtiveram encolhimento tenham sido submetidos a temperaturas letais. Assim, a extensão real da lesão tecidual não pode ser exatamente refletida pela impressão visual da quantia de encolhimento.

Alguns traumas ou desvitalização tecidual induzem uma resposta inflamatória conduzindo para o reparo e a remoção ou substituição do tecido lesado. Este processo é mais prolongado após a lesão térmica e após a lesão traumática incisional. Estudos experimentais numerosos têm documentado que tecidos modificados termicamente sofrem um reparo e processo de remodelação por fibroplasia, aumentando a deposição de colágeno, e a fase de remodelação com a qual o perfil biográfico do diâmetro do colágeno muda vindo das duas modalidades, grande e pequeno diâmetro. Estas trocas morfológicas são associadas com a diminuição na rigidez de tensão, a estrutura do tecido susceptível ao alongamento devido ao estiramento do tecido.

Estudos têm sugerido que pelo menos são requeridos 3 meses depois da modificação térmica para o tecido poder recuperar as suas propriedades biomecânicas completamente. Restrições de atividades durante um tempo é uma consideração recomendada para a norma pós-operatória. Embora isto pareça que a manutenção do encolhimento inicial é diretamente dependente do controle do estresse pós-operatório exercido no tecido é 
indiretamente dependente da quantia do encolhimento induzido na ocasião da cirurgia (AKSAN, ARNOCZKY, 2000).

\section{I.4.3.3. Renaturação das proteínas}

Quando as condições para a desnaturação são moderadas, a proteína pode recuperar sua configuração original pela reversão cuidadosa das condições que causaram a desnaturação. Esse processo é chamado de desnaturação reversível (Figura 5).

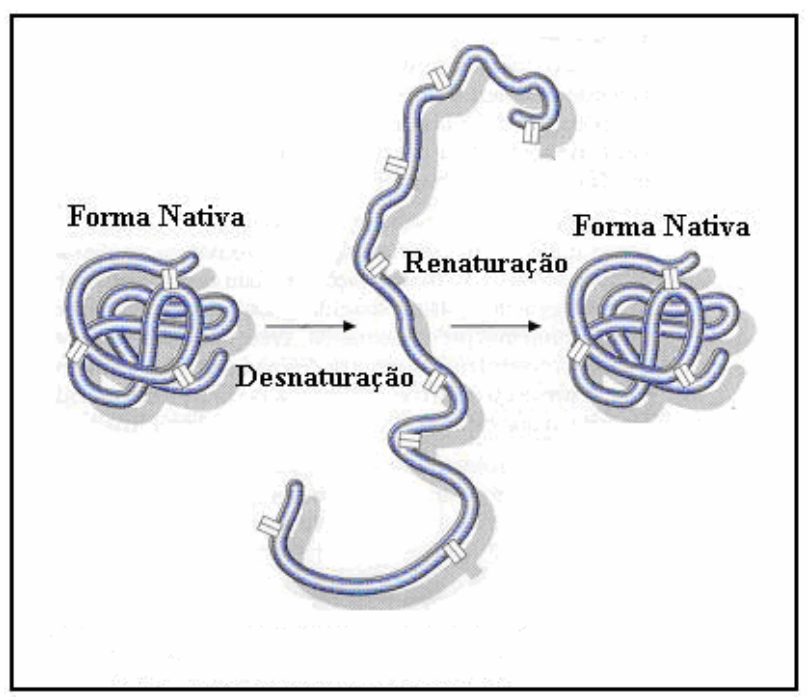

Figura 5. Desnaturação reversível.

Fonte: SACKHEIM \& LEHMAN, 2001.

Tecidos colagenosos consistem principalmente de água, que desempenha um papel significativo em suas propriedades globais (CHIMICH et al. 1992; HAUT e HAUT, 1997).

Weir (1949) demonstrou que a taxa de encolhimento, em conseqüência da desnaturação, aumenta com o aumento da hidratação em determinada temperatura. O nível de hidratação pode variar, por sua vez, devido ao aquecimento.

Luescher et al., (1974) sugerem que primeiramente hidratação de água é ajustada livremente durante o processo de desnaturação é lentamente ressaltada à proteína amorfa, que 
se submete desse modo a uma renaturação parcial, além disso, sugere que esta renaturação parcial é devida, em parte, à formação de pontes adicionais de água dentro da molécula mais desorganizada. No nível do tecido, esta absorção de água ocorre provavelmente com tempos característicos na ordem de horas que seguem o aquecimento e a restauração à temperatura do corpo. Hörmann e Schlebusch (1971) sugerem também que a renaturação é maior se o tecido for mantido sob a carga porque a carga aumentada tende a organizar a estrutura e a promover desse modo a correção de algumas estruturas da hélice tripla. Esta possibilidade enfatiza a importância do acoplamento termomecânico. Há uma necessidade rápida de quantificar ao transporte de fluido devido aos danos térmicos.

\section{I.5. Técnicas de avaliação}

\section{I.5.1. Microscopia de polarização}

Através da microscopia de polarização é possível analisar as fibras de colágeno devido a uma propriedade existente neste tecido, a anisotrópica óptica, que se refere à birrefringência de forma textural, bem como a ordem molecular, da direção da vibração, de momento de transição e de variação nos estados de agregação molecular (VIDAL, 1987a, b).

Um feixe de luz ao incidir em um polarizador ideal (Pol), transmite apenas o seu componente com campo paralelo ao seu eixo de transmissão. No microscópio de luz polarizada há um segundo polarizador idêntico ao primeiro, o analisador (An), com eixo de transmissão orientado verticalmente. Desse modo, a irradiância é máxima quando os eixos de transmissão entre Pol e An é nulo, é mínima ou ausente quando essa angulação é de $90^{\circ}$, 
segundo a Lei de Malus (FALK et al, 1986).

O microscópio de luz polarizada é feito de dois filtros polarizadores: o Polarizador (Pol) e o Analisador (An). O Pol está localizado abaixo do condensador do microscópio óptico, e possibilita se mover para ser removido ou colocado no trajeto da luz, além de uma rotação de $360^{\circ}$, já o An é um polarizador que está acima das objetivas e abaixo das oculares, assim, a luz polarizada (com o vetor elétrico vibrante e um só plano) emitida, encontrará o plano de polarização do analisador perpendicular à sua direção de vibração, analisando que, esse processo ocorre pela própria natureza dos polarizadores.

Os dois polarizadores Pol e An são feitos por placas de plásticos laminados, onde ocorre estriação e orientação na direção da força de laminação das moléculas de polímeros, além de serem coradas por solução de iodo ou por seu derivado de quinina, o qual se depositará na mesma direção das moléculas do polímero.

Estas peculiaridades deixarão passar apenas energia radiante em uma direção, aquela que corresponde ao seu plano de polarização, fazendo com que a placa polarizada tenha absorção de todos os vetores elétricos da radiação visível de forma seletiva. Por isso quando o Pol e An estiverem paralelos entre si a intensidade de passagem de luz será máxima, pois toda radiação polarizada perpendicularmente ao plano de polarização do analisador será absorvida (VIDAL, 1987b).

\section{I.5.2. Propriedades anisotrópicas ópticas}

As propriedades anisotrópicas ópticas têm a capacidade de assimilar e absorver de forma seletiva a luz polarizada emitida pelo microscópio óptico, na qual as propriedades 
anisotrópicas ópticas são a birrefringência e o dicroísmo linear, onde estes dois aspectos de uma mesma propriedade possuem a mesma informação.

O dicroísmo linear é a propriedade de apresentar duas cores, onde geralmente uma delas tem como origem a luz refletida e a outra tem a luz transmitida, mas em sistemas onde se tem pouca organização e orientação, é raro de se detectar o dicroísmo linear, o que já não acontece com a birrefringência.

A anisiotropia óptica não apresenta as mesmas propriedades ópticas em todas as direções em um mesmo material, mas estas mesmas propriedades estão presentes em diversos materiais que possuem substâncias cristalinas sólidas onde os átomos estão dispostos de maneira regular (HECHT,1991).

A luz ao atravessar um material isotrópico tem uma velocidade de propagação constante, em qualquer direção deste corpo, no que diz respeito ao seu índice de refração (Figura 6).

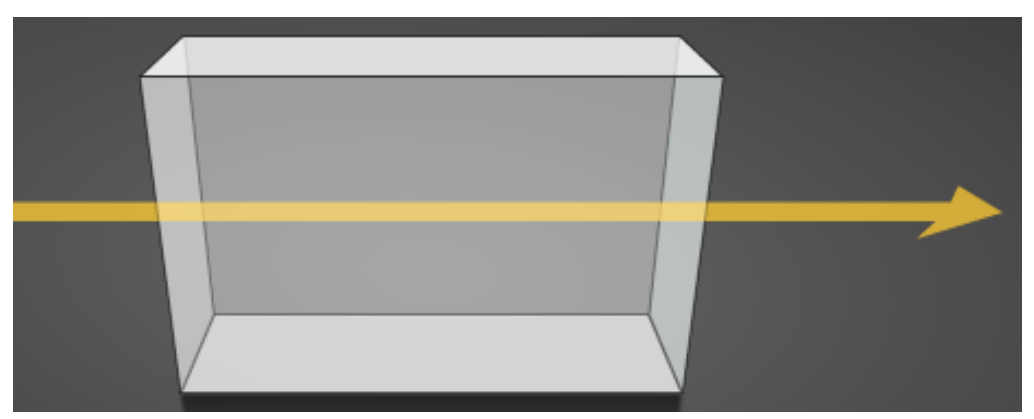

Figura 6. Representação esquemática da luz polarizada ao atravessar um material sem birrefringência.

Fonte: Exicor.com

Segundo Vidal (1987b), em um material anisiotrópico, a luz ao atravessar birrefingente se propaga em duas direções difrentes, pois o material birrefringente possui dois índices de refração diferentes (Figura 7). 


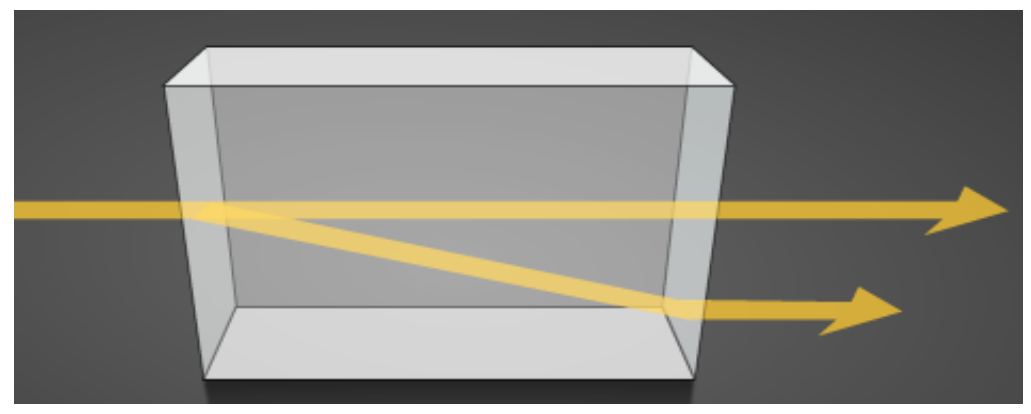

Figura 7. Representação esquemática da luz polarizada ao atravessar o material com birrefringência.

Fonte: Exicor.com

\section{I.5.3. Birrefringência de materiais (VIDAL 1987 a e b)}

Considera-se birrefringência uma propriedade anisotrópica óptica, através da qual se pode determinar e quantificar a ordenação macromolecular das estruturas biológicas, informando sobre a morfologia e direção das fibras colágeno, sua distribuição e seu grau de associação, através da propagação desigual da luz, em um material biológico.

Um raio de luz polarizado ao atravessar um material anisotrópico orientado adequadamente, sofre o fenômeno da dupla refração, com o aparecimento de dois raios refratados: um lento e outro rápido, cujas velocidades são inversamente proporcionais aos índices de refração. A diferença numérica entre estes dois índices de refração, recebe o nome de birrefringência.

O material apresenta diferentes índices de refração em determinadas direções, as quais são perpendiculares umas as outras no corpo birrefringente.

O material birrefringente ao ser analisado pela microscopia de polarização, apresenta um brilho intenso exibido pelas fibras e fibrilas, correspondentes aos índices de refração, quando são posicionadas à $45^{\circ}$ do plano de polarização de luz (Figuras 8 e 9), esta alta intensidade de 
brilho é proporcional a espessura do material em análise e a diferença de fase entre as frentes de luz emergentes ao material em análise.

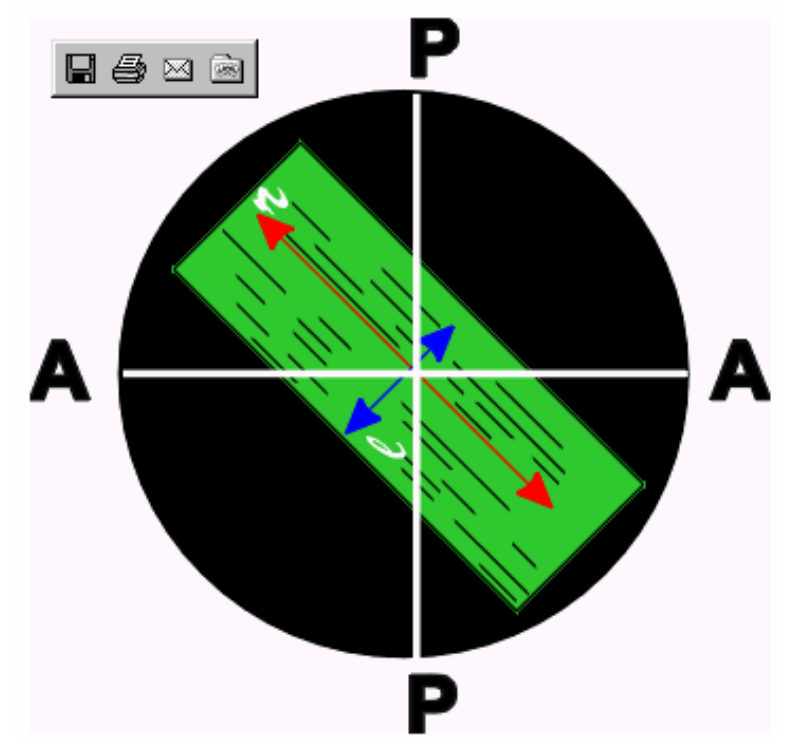

Figura 8. Representação do material em análise, orientado em um ângulo de $45^{\circ}$ à esquerda do plano de polarização onde o raio rápido e lento não estão paralelos ao polarizador e analisador, apresentando um intenso brilho característico.

Fonte: NARDY, 2006

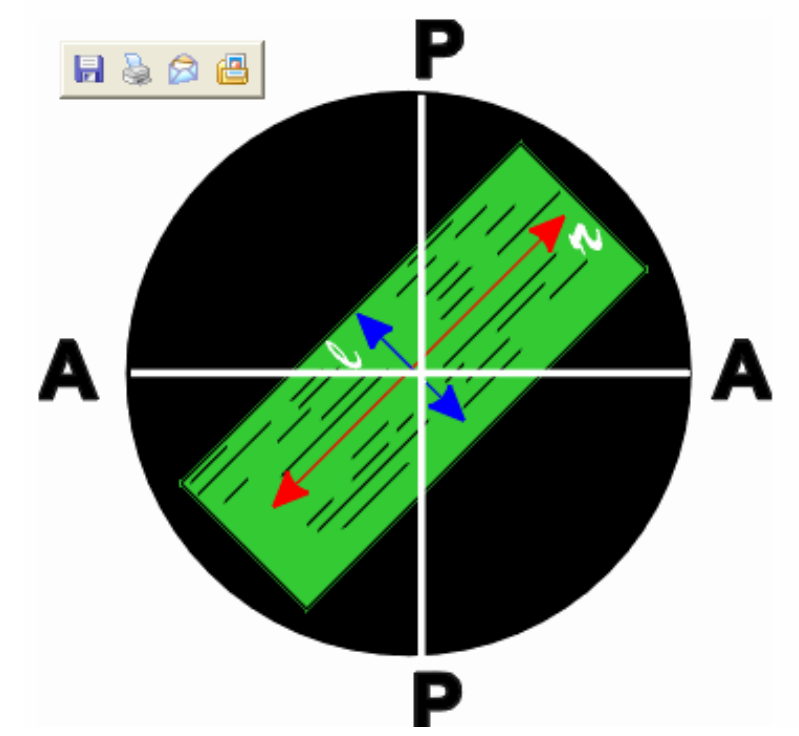

Figura 9. Representação do material em análise, orientado em um ângulo de $45^{\circ}$ à direita do plano de polarização onde o raio rápido e lento não estão paralelos ao polarizador e analisador, apresentando um intenso brilho característico.

Fonte: NARDY, 2006 
Todo material anisotrópico óptico quando observado, apresenta extinto (ângulo de extinção) toda vez que suas direções de vibrações principais coincidirem com o polarizador e analisador do microscópio óptico, ou seja, os eixos de propagação do material estão paralelos ao analisador e ao polarizador, que posteriormente proporciona o desaparecimento das imagens birrefringentes do material, escurecendo o material em análise (Figura 10).

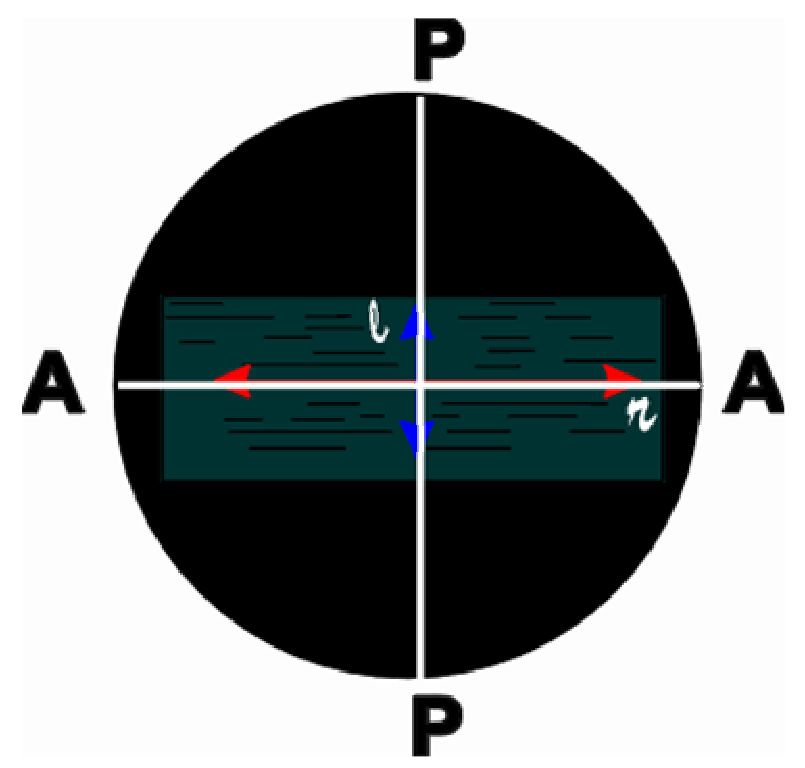

Figura 10. Representação do material em análise, orientado em um ângulo de $0^{\circ}$ do plano de polarização onde os raios rápido e lento estão paralelos ao polarizador e analisador, proporciona o desaparecimento das imagens birrefringentes e um escurecimento da imagem. Fonte: NARDY, 2006

A luz polarizada por meio da microscopia de polarização, ao refletir em um material birrefringente irá se propagar de duas formas diferentes de trajetos ópticos, onde um irá na direção do raio ordinário e outro na direção do raio extraordinário. Devido a essa diferença de trajeto óptico ou retardo óptico $(\mathrm{RO})$.

Se expressa quantitativamente a birrefringência em termos de retardos ópticos e usando nanômetros como unidades. 
A birrefringência e o retardo óptico podem ser expressos pelas equações:
$\mathbf{B}=\left(\mathrm{n}_{0}-\mathrm{n}_{\mathrm{E}}\right)$
(Equação 1)
$\mathbf{O R}=\left(\mathrm{n}_{0}-\mathrm{n}_{\mathrm{E}}\right) \times \mathrm{t}$,
(Equação 2)
$\mathbf{O R}=\mathrm{B} \times \mathrm{t}$
(Equação 3)

\section{Onde:}

$\mathbf{t}=$ espessura do corpo.

$\mathbf{B}=$ Birrefringência

RO $=$ Retardo Óptico

$\mathbf{n}_{\mathbf{0}}$ = índice de refração do meio na direção onde se propaga o raio ordinário

$\mathbf{n}_{\mathbf{E}}=$ índice de refração do meio na direção onde se propaga o raio extraordinário

Birrefringência de forma (BF) ou textural é o tipo de birrefringência do colágeno. A birrefringência textural ou de forma por outro lado depende da geometria das moléculas, das concentrações, orientação, estado de agregação molecular e das diferenças entre seus índices de refração, dos componentes dos feixes de colágeno, ocorrendo devido a presença de microcorpos com morfologia assimétrica dispostas ordenadamente, de tal forma que seus diâmetros e distâncias sejam menores que o comprimento de onda $(\lambda)$, sendo dependentes dos índices de refração, da contribuição dos volumes parciais das partículas e do meio homogêneo dispersante.

Os feixes colágenos, além da $\mathrm{BF}$, apresentam também uma birrefringência intrínseca positiva, onde a birrefringência intrínsica correspondem as médias de todas as transições de elétrons entre as ligações peptídicas, estabelecendo informações sobre a direção de vibração e ressonância dos elétrons da região de ligação peptídica na molécula de colágeno ao longo da fibra, dando maiores informações de natureza micromorfológica, porque evidencia a fibra colágeno pela sua birrefingência. 
Alterações dos meios de imersão dos feixes colágenos, em diferentes índices de refração (n), permite estudar suas propriedades ópticas como a birrefringência. A imersão do colágeno nestes meios fará com que possa ser vista a variação de brilho deste, isto o que o valor da BF varia com o n do meio de imersão.

A curva de birrefringência é determinada pela plotagem dos valores de retardos ópticos (RO em nm) das fibras de colágeno em função do índice de refração médio dos fluidos de imersão, com a água destilada $(n=1,333) ; 20 \%, 30 \%, 40 \%, 60 \%, 80 \%, 100 \%$ de soluções de glicerina, cujos $\mathrm{n}=1,3600 ; 1,3724 ; 1,3864 ; 1,4131 ; 1,4353$; e 1,4610, respectivamente; e finalmente o Nujol $(n=1,4786)$.

A curva de BF do colágeno é observada ao utilizar substâncias fluidas que não penetram ou que reagem com os tecidos, por isso não se deve utilizar estas substâncias fluidas, o que irá alterar as respostas birrefringentes do material.

É recomendado utilizar água destilada, pois nesta situação os feixes de fibras colágenas apresentam maiores valores de birrefingência, correspondendo aos valores da birrefringência total, isto é, representam os valores da BF somada a birrefringência intrínseca, e podem representar com objetividade a morfologia das moléculas de colágeno, o diâmetro e grau de empacotamento das fibras.

O valor da birrefringência total aumentado está relacionado ao aumento de ligações cruzadas entre as fibrilas de colágeno, tornando mais intensa a cristalinidade e agregação ordenada do colágeno tipo I. Onde modificações foram encontradas nas curvas de birrefringência, as quais foram relacionadas ao grau de agregação ordenada lateralmente das fibras. Diferença nos estados organizacionais de um mesmo tipo de colágeno podem ser encontradas em função da idade e localização topográfica. 


\section{I.6. Calorimetria exploratória diferencial (DSC)}

\section{I.6.1. Estabilidade térmica}

A origem microscópica de calor, ou seja, a origem em escala molecular é o movimento das moléculas no material. Os movimentos de translação, rotação e vibração causam sensação de calor. Resumidamente, o calor macroscópico tem sua origem microscópica no movimento molecular.

Através das avaliações de um programa controlado de temperatura é que são realizadas as análises térmicas e as propriedades físicas de um material. Os efeitos de temperatura sobre colágeno têm sido estudados utilizando-se as técnicas de calorimetria exploratória diferencial (DSC).

No sistema DSC o suporte da amostra e da referência tem um sensor resistor que mede a temperatura da base do suporte e do resistor que aquece. Se uma diferença de temperatura é detectada entre a amostra e a referência, por causa de uma mudança de fase na amostra, o equipamento fornece energia até que a diferença de temperatura seja menor que 0,01 K. A adição de energia por unidade de tempo é registrada como uma função do tempo ou temperatura. Uma consideração simplificada de propriedade dessa configuração mostra que a adição de energia é proporcional a capacidade calorífica da amostra.

A análise calorimétrica por DSC (Figura 11) permite a medida de estabilidade das estruturas helicoidais das moléculas de colágeno, relativas à transição colágeno $\rightarrow$ gelatina. A quebra da estrutura da hélice tripla dá lugar a uma estrutura amorfa formada por cadeias polipeptídicas: $\alpha_{3}$ (hélice tripla) $\rightarrow$ cadeias $\alpha, \beta$ e $\gamma$ de polipeptídicos (gelatina). 


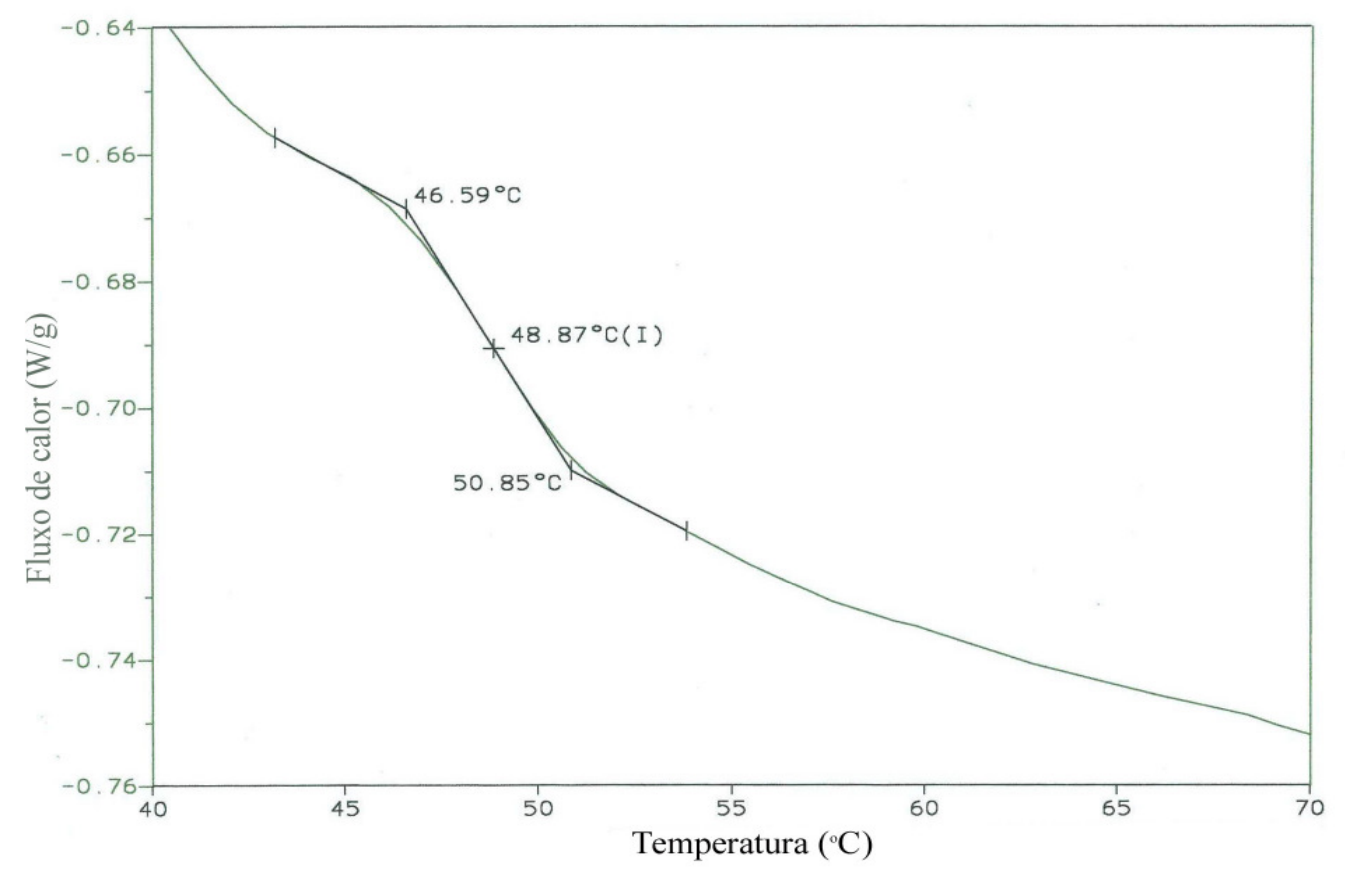

Figura 11. Curva de DSC demonstrativa da região de desnaturação.

A transição vítrea se refere ao intervalo de temperatura na qual o material polimérico (colágeno) muda de um estado mais ordenado hélice tripla para um estado menos ordenado (amorfo). Essa transição aparece como uma descontinuidade na linha de base, que é proporcional a diferença na capacidade de calor antes e após a desnaturação. Neste trabalho foi considerado como temperatura de desnaturação o ponto de inflexão (I) da curva. 


\section{OBJETIVOS}

Este trabalho tem como objetivo verificar se o aquecimento in vivo por convecção do tendão calcâneo de ratos promove alguma alteração de ordem estrutural na proteína colágeno. 


\section{MATERIAIS E MÉTODOS}

\section{III.1 Animais}

Para a realização do presente trabalho experimental foram utilizado 48 ratos (Rattus Albinus Novergicus) da raça Wistar, machos, saudáveis, adultos, com peso corporal entre $300 \mathrm{~g}$ e $500 \mathrm{~g}$ e cerca de 100 dias de vida, obtidos no biotério central da Universidade Estadual Paulista - UNESP de Araçatuba. Os animais foram distribuídos em gaiolas apropriadas de polietileno padrão, em grupos com 6 animais onde permaneceram durante todo o decorrer da fase pré-experimental, objetivando o consumo mais homogêneo da ração administrada.

De acordo com protocolo $\mathrm{n}^{\mathrm{o}} 78 / 05$, o presente trabalho, sob responsabilidade de Ana Maria de Guzzi Plepis, Rubens dos Santos Rosa e Ana Maria Pires Soubhia, está de acordo com os Princípios Éticos na Experimentação Animal adotado pelo Colégio Brasileiro de Experimentação Animal (COBEA) sendo aprovado pela Comissão de Ética em Experimentação Animal (CEEA) da Universidade Estadual Paulista - UNESP de Araçatuba em reunião no dia 16 de junho de 2005, presidida pela Prof ${ }^{a}$ Ass. Dr. Maria Gisela Laranjeira. (Anexo 1).

Os animais foram mantidos durante todo experimento no Biotério do Laboratório de Patologia e Propedêutica Clínica, na Faculdade de Odontologia de Araçatuba Universidade Estadual Paulista - UNESP, e mantidos por pelo menos 72 horas no novo ambiente para aclimatação, com condições ambientais controladas, iluminação com ciclos de 12 horas (claro/escuro) e ambiente higienizado, com água e alimentação à vontade. 
Os 48 animais foram divididos aleatoriamente em 8 grupos, sendo que 1 animal de cada grupo foi separado para análises de calorimetria exploratória diferencial (DSC).

Os grupos foram denominados desta forma:

Grupo I - Controle: os animais deste grupo não foram submetidos a nenhum tipo de experimento e/ou tratamento.

Os animais dos seguintes grupos correlatados foram submetidos a tratamento de banhos hidrotérmicos nas seguintes temperaturas:

\footnotetext{
Grupo II $-35^{\circ} \mathrm{C}$

Grupo III - $40^{\circ} \mathrm{C}$

Grupo IV - $42^{\circ} \mathrm{C}$

Grupo V $-45^{\circ} \mathrm{C}$

Grupo VI - $48^{\circ} \mathrm{C}$

Grupo VII $-50^{\circ} \mathrm{C}$

Grupo VIII - $55^{\circ} \mathrm{C}$.
}

Nos grupos dos animais tratados os animais foram imobilizados em um contensor, e submetidos ao experimento, submergindo os membros inferiores em água aquecida em temperatura variável, por 10 minutos. Para tal realização utilizou-se um recipiente com água aquecida com um termostato embutido da empresa Fanem Ltda e um termômetro convencional com a finalidade de manutenção constante de temperatura da água aquecida e temperatura desejada (Figura 12). 


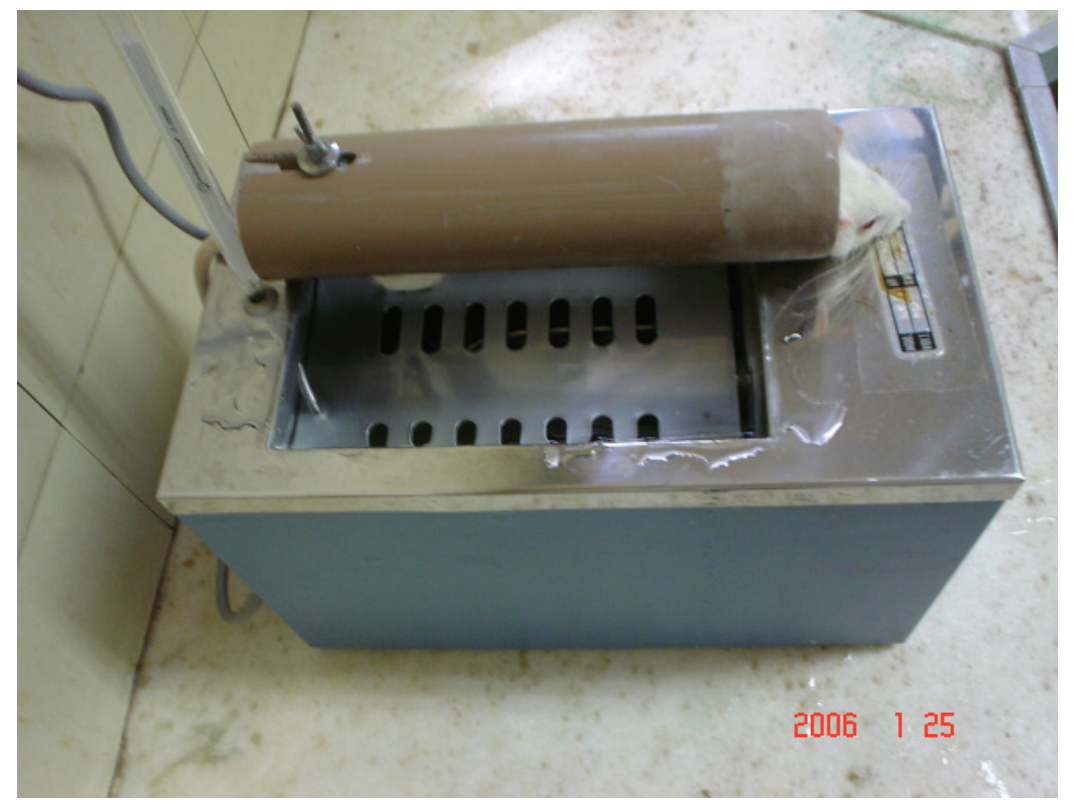

Figura 12. Banho hidrotérmico utilizando um contensor para imobilização específica de rato

\section{III.2. Procedimento experimental}

Anteriormente ao experimento e/ou tratamento todos os animais foram pesados, e em seguida anestesiados por injeção intra-peritoneal de anestésico Ketamina (Francotar ${ }^{\circledR}$ $10 \mathrm{~mL}$ - uso veterinário, Virbac do Brasil Ind. Com Ltda), na dosagem de 0,08mL para cada $100 \mathrm{~g}$ de peso corporal, associado ao relaxante muscular e analgésico Cloridrato de Xylazina (Virbaxyl ${ }^{\circledR} 2 \%$ - 10mL - uso veterinário, Virbac do Brasil Ind. Com Ltda.) na dosagem de $0,04 \mathrm{~mL}$ para cada $100 \mathrm{~g}$ de peso corporal. Todo este procedimento foi realizado utilizando uma seringa de insulina ( $1 \mathrm{~mL})$ e após os animais serem anestesiados, os membros inferiores foram submergidos em água aquecida à temperatura desejada, por 10 minutos. 


\section{III.3. Procedimento cirúrgico}

Após o procedimento experimental cada animal fora sacrificado com doses excessivas do anestésico Thiopental, imobilizados em uma prancha específica para tal e submetido à tricotomia da região calcanear, sendo que seus tendões foram extirpados cirurgicamente como um todo, desde a origem miotendínea até a inserção calcanear. Por meio de uma pequena incisão sobre a pele o tendão foi dissecado, tenotomizado e retirado para análise microscópica, sendo que os mesmos foram submersos e fixados em formol a 10\%, por 48 horas logo após a tenotomia, (Figura 13, 14 e 15). Finalizado este processo, todos os tendões foram colocados em recipientes específicos para serem lavados em água corrente por 24 horas.

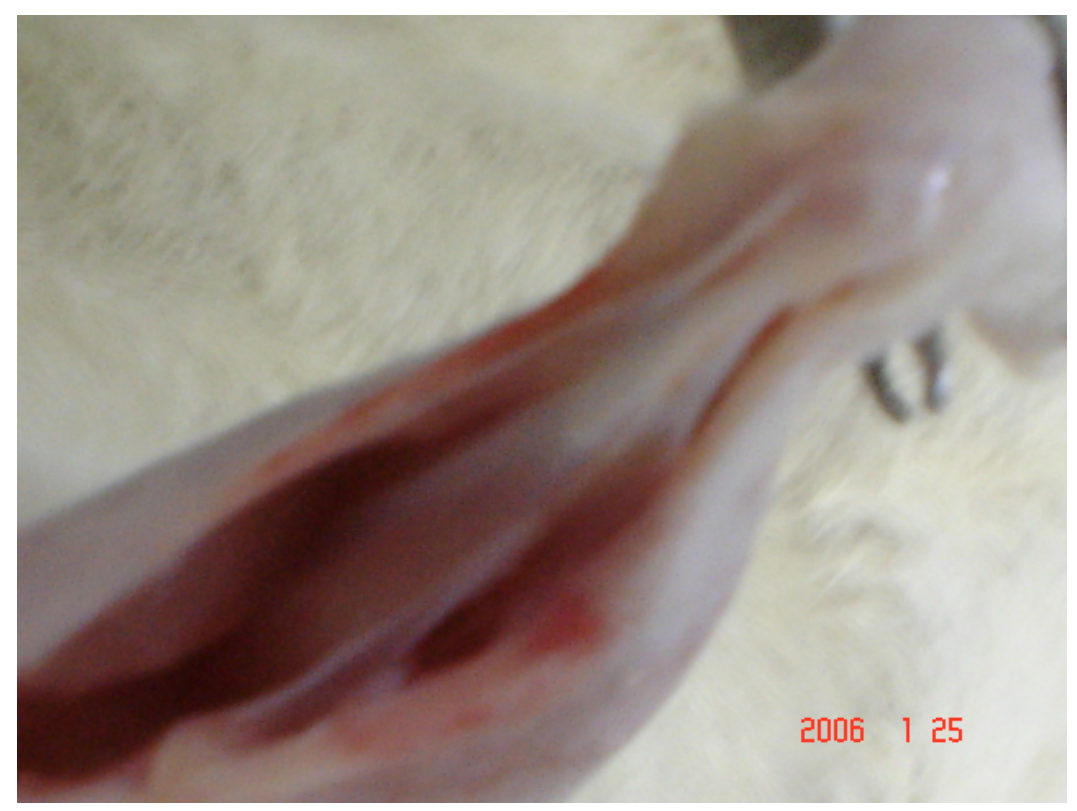

Figura 13. Dissecação do tendão calcâneo 


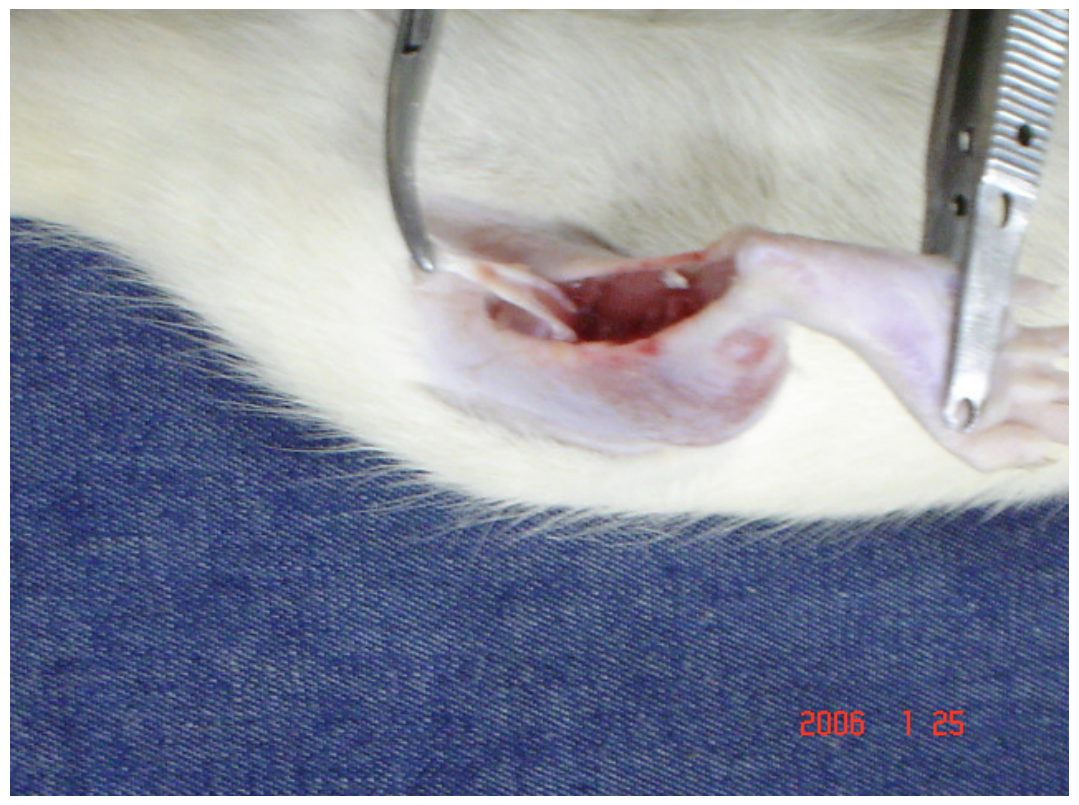

Figura 14. Tenotomização do tendão calcâneo

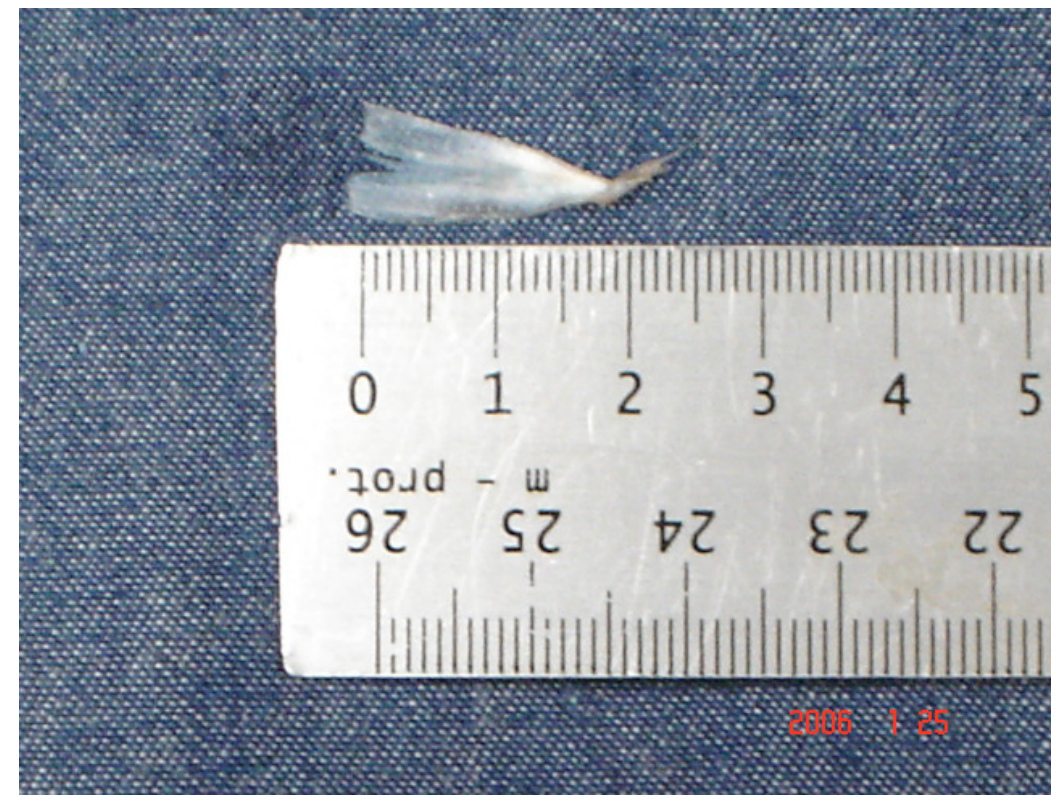

Figura 15. Amostra do tendão calcâneo dissecado e extirpado cirurgicamente como um todo. 


\section{III.4. Preparação dos tecidos (tendões). Protocolos de colorações (Gartner e} Hiatt, 2003)

De acordo com Gartner e Hiatt (2003) várias técnicas foram desenvolvidas para preparar os tecidos a serem estudados para manterem um aspecto muito próximo do seu estado natural vivo. As etapas envolvidas são:

- Fixação: é o tratamento dos tecidos com agentes químicos que não somente retardam as alterações dos tecidos subseqüentes à morte (após sua remoção do corpo), mantendo a arquitetura normal, os agentes fixadores mais comum são formol e o líquido de Bouin.

- Desidratação e diafanização: como grande fração dos tecidos é composta de água, é usada uma série de banhos de álcool em concentrações crescentes, começando com álcool $70 \%$ e subindo gradualmente até chegar a $100 \%$, a fim de remover a água (desidratação): os tecidos então são tratados com xilol, um produto químico miscível com parafina fundida. Este processo é denominado diafanização. Pois os tecidos tornam-se transparentes no xilol.

- Inclusão: a fim de destingüir as células de um tecido da matriz extracelular, na histologia precisam-se incluir os tecidos em um meio apropriado e cortá-los em cortes finos. Para a microscopia óptica, o meio de inclusão usual é a parafina, onde o tecido é colocado em um recipiente adequado contendo parafina fundida até tornar-se totalmente infiltrado. Uma vez impregnado com parafina, ele é colocado em um pequeno recipiente, coberto com parafina fundida e deixado até endurecer, formando um bloco de parafina contendo o tecido.

- Microtomia: depois de os blocos terem sido aparados de modo a remover o excesso em material de inclusão, eles são montados para microtomia. Esta tarefa é efetuada 
usando um micrótomo (Figura 16), uma máquina equipada com uma lâmina de aço inoxidável que realiza cortes específicos para microscopia óptica com espessuras de cerca de 5 a $10 \mu \mathrm{m}$.

- Montagem das lâminas histológicas: após as peças passarem por cortes específicos feitos pelo micrótomo, os tecidos são aderidos e montados em lâminas histológicas de vidro revestido com adesivo, após este procedimento a parafina é removida da lâmina, posteriormente o tecido é reidratado e corado.

- Coloração: como muitos constituintes dos tecidos têm densidades ópticas muito próximas, eles precisam ser corados para a microscopia óptica, usando principalmente corantes solúveis em água, após a coloração o corte é novamente desidratado para possibilitar que uma lamínula seja afixada de modo permanente, pra proteger de danos como é necessário para observação do corte ao microscópio.

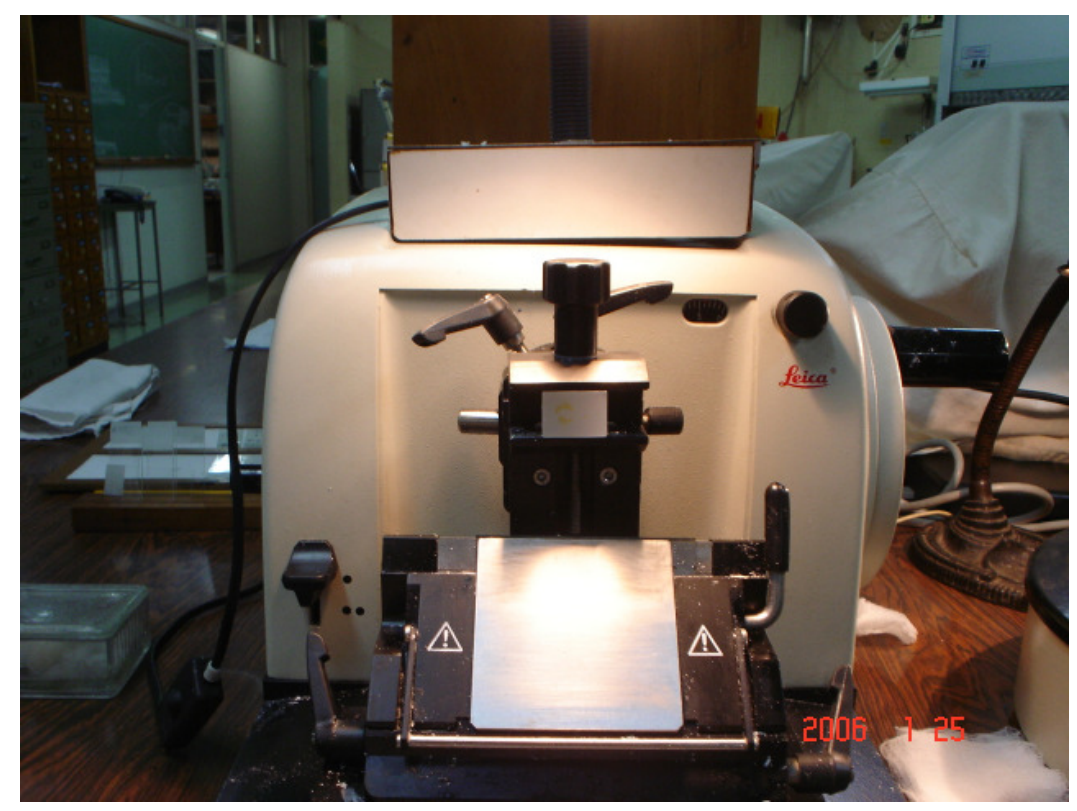

Figura 16. Micrótomo Leica 


\section{III.5. Notas técnicas sobre coloração (Young e Heath, 2003)}

\section{III.5.1 Hematoxilina e eosina (H \& E)}

Esta técnica é mais comumente usada em histologia animal e na rotina da patologia. O corante básico, a hematoxilina, cora as estruturas ácidas em azul tirante ao púrpura. Em contraste, a eosina é um corante ácido que cora as estruturas básicas em vermelho ou em rosa, em geral, quando a técnica de coloração por hematoxilina e eosina é aplicada em células animais, os núcleos se coram em azul e o citoplasma, em rosa ou vermelho.

\section{III.5.2 Tricrômico de Masson}

Esta técnica é uma das chamadas técnicas para tecido conjuntivo, já que é usada para demonstrar elementos do tecido de sustentação, principalmente colágeno, esta técnica produz três cores: os núcleos são corados em azul, o colágeno é corado em verde ou azul, dependendo de qual das variantes da técnica for utilizada, o citoplasma e o músculo são corados em vermelho brilhante.

\section{III.6. Preparação das lâminas para análises histológicas}

As lâminas foram montadas com o auxílio da Prof ${ }^{a}$ Ana Maria Pires Soubhia do Departamento de Patologia e Propedêutica Clínica, na Faculdade de Odontologia de Araçatuba Universidade Estadual Paulista - UNESP. Os tendões removidos foram fixados por 
48 horas em formol a $10 \%$, em seguida os mesmos foram lavados por 24 horas em água corrente. Após este procedimento os tendões foram desidratados em soluções crescentes de álcool etílico, a 70\%, 90\%, 95\%, por uma hora em cada solução e a 100\%, sendo este repetido por 3 vezes por 1 hora cada. Após os banhos de desidratação, as peças foram diafanizadas em 3 banhos de xilol; a duração de cada banho foi de 1 hora. As peças foram retiradas do xilol e colocadas imediatamente em parafina líquida $\left(60^{\circ} \mathrm{C}\right)$, em 3 banhos consecutivos de 1 hora cada banho. Após este procedimento, foi feita a inclusão em blocos de parafina, para a realização do corte das peças. As peças, inclusas nos blocos de parafina, foram cortadas longitudinalmente por meio de um micrótomo Leica modelo RM 2125 RT, com espessura padronizada de $5 \mu \mathrm{m}$.

Após este procedimento, cada lâmina histológica foi montada com uma série de no mínimo 5 cortes consecutivos de cada peça e cada grupo de animais foi representados por 8 lâminas histológicas montadas com seus respectivos tendões. Após serem montadas, todas as lâminas foram desparafinizadas, hidratadas e coradas com Hematoxilina e Eosina e Tricrômico de Masson para análise histológica em microscopia de luz, com objetivo de reproduzir imagens ampliadas para revelarem detalhes das estruturas dos tecidos.

\section{III.7. Preparação das lâminas para análises de microscopia de polarização}

Após serem inclusas nos blocos de parafina, as peças foram cortadas longitudinalmente por micrótomo. As lâminas para análises de microscopia de polarização foram então montadas em lâminas histológicas com cortes padronizados de $7 \mu \mathrm{m}$, montados em lâminas histológicas sem cobertura por lamínulas e/ou coloração. Cada lâmina histológica foi montada com uma série de no mínimo 5 cortes consecutivos de cada peça e cada grupo de 
animais foi representado por 8 lâminas histológicas montadas com seus respectivos tendões. Após serem montadas, todas as lâminas foram desparafinizadas e hidratadas novamente.

\section{III.8. Medidas de birrefringência}

A análise das fibras de colágeno foi possível graças a uma propriedade deste tecido conhecida como anisotropia óptica no que refere a birrefringência de forma textural, através da microscopia de polarização.

Através da microscopia de luz polarizada, foi possível analisar as fibras de colágeno, utilizando uma de suas propriedades anisotrópicas ópticas, a birrefringência de forma ou textural.

Todas as lâminas de cada grupo foram submersas em água destilada, com intuito de uma análise de birrefringência total de lâminas histológicas de forma precisa, onde o índice de refração é de $(\mathrm{n}=1,333)$, conforme descreve VIDAL em suas pesquisas (1987b).

As medidas dos retardos ópticos $(\mathrm{RO} \mathrm{em} \mathrm{nm})$ em $\mathrm{H}_{2} \mathrm{O}$ representam à soma das birrefringências intrínsecas e textural dos feixes de colágeno.

Todas as lâminas antes de serem analisadas foram cobertas por lamínulas, após o período de imersão em água destilada de no mínimo 30 minutos, contendo água destilada nas interfaces. As medidas dos retardos ópticos (RO) foram obtidas pela microscopia de luz polarizada no microscópio Leica DMRX, com uma objetiva Pol 10x/0,22, condensador 0,0, compensador Sénarmont's $\lambda / 4$, monocromática $\lambda=546 \mathrm{~nm}$, obtida por meio de um filtro de interferência Leica, no Departamento de Engenharia de Materiais, da UFSCar, sob a supervisão e orientação do Prof. Dr. Oscar Peitl Filho. 
As medidas de birrefringência só foram possíveis com a orientação do eixo longo do tendão à $45^{\circ}$ em relação aos polarizados do microscópio, pois é exatamente nesta posição que as fibras de colágeno exibem um maior brilho e conseqüentemente um alto valor de retardo óptico (RO), desta forma, as medidas foram realizadas nas fibras posicionadas predominantemente paralelas ao eixo longo do tendão, e representam o retardo óptico (RO) exibido nos diferentes grupos.

\section{III.9. Análises de calorimetria exploratória diferencial (DSC)}

Para a efetuação dos estudos de calorimetria exploratória diferencial (DSC) utilizou-se $10 \mathrm{mg}$ das amostras de tendões, que foram colocadas em porta amostras de alumínio não hermético e submetidas à razão de aquecimento $10^{\circ} \mathrm{Cmin}^{-1}$ em atmosfera dinâmica de nitrogênio $\left(90 \mathrm{mLmin}^{-1}\right)$, numa faixa de 25 a $250^{\circ} \mathrm{C}$. Essas medidas determinaram a temperatura de desnaturação do colágeno e foram realizadas em um equipamento de DSC 2010 da TA Instruments.

\section{ANÁLISE ESTATÍSCA}

A análise estatística se constitui na análise e interpretação de dados visando uma avaliação objetiva de um processo aleatório. A análise estatística foi feita através do programa ESTATÍSCA 3.0, para análise simultânea dos grupos foi utilizado o teste ANOVA. 


\section{RESULTADOS E DISCUSSÃO}

\section{V.1. Análise macroscópica e visual dos animais durante e após o banho hidrotérmico}

Através de uma análise macroscópica e visual observou-se que os animais tiveram um comportamento e uma aparência cutânea dentro do normal quando seus membros foram submergidos em baixas temperaturas $\left(35\right.$ a $\left.42^{\circ} \mathrm{C}\right)$, o mesmo não pôde ser observado em temperaturas mais altas $\left(45\right.$ a $\left.55^{\circ} \mathrm{C}\right)$, pelo fato dos animais terem apresentados lesões cutâneas periféricas disseminadas mais evidentes na região distal do membro inferior, e uma rigidez tendínea aumentada.

No momento da tenotomização, observou-se um encolhimento tendíneo, e posteriormente uma dificuldade de extirpação do mesmo, o que não ocorreu com os tendões dos animais que sofreram o experimento em temperaturas mais amenas $\left(35,40\right.$ e $\left.42^{\circ} \mathrm{C}\right)$.

\section{V.2. Análises de medidas de birrefringência}

Foram realizadas 100 medidas de retardos ópticos (RO) para as medidas de birrefringência, para cada grupo em diferentes pontos das regiões centrais dos tendões. Os oito grupos estudados foram analisados rigorosamente com aplicação de métodos estatísticos, com aplicação de um teste de parâmetros apropriado, com análise de variância (ANOVA), havendo homegeinidade nas variâncias dos grupos. 
Os resultados alcançados foram organizados na tabela abaixo, portanto quanto menores forem os valores numéricos obtidos das medidas de birrefringência piores serão os resultados com relação à organização estrutural das fibras de colágeno devido à aplicação de aquecimento local.

Tabela 1. Dados observados nos oito grupos analisados e suas medidas descritivas em relação aos valores de birrefringência, através dos retardos ópticos (RO).

\begin{tabular}{|l|r|r|r|r|r|r|r|r}
\hline & \multicolumn{7}{|c|}{ Grupos } \\
\cline { 2 - 10 } & \multicolumn{1}{|c|}{$\mathbf{1}$} & \multicolumn{1}{|c|}{$\mathbf{2}$} & \multicolumn{1}{|c|}{$\mathbf{3}$} & $\mathbf{4}$ & \multicolumn{1}{|c|}{$\mathbf{5}$} & $\mathbf{6}$ & $\mathbf{7}$ & \multicolumn{1}{c|}{$\mathbf{8}$} \\
\hline Média (nm) & 74,73 & 68,91 & 70,01 & 75,52 & 53,46 & 46,27 & 37,02 & 34,13 \\
\hline Mediana (nm) & 74,99 & 68,78 & 70,29 & 76,65 & 53,78 & 45,29 & 37,26 & 33,93 \\
\hline Desvio padrão (nm) & 6,42 & 7,18 & 8,85 & 8,66 & 6,06 & 7,75 & 8,25 & 5,48 \\
\hline Mínimo (nm) & 60,90 & 54,84 & 48,17 & 60,90 & 40,29 & 31,20 & 18,18 & 18,78 \\
\hline Máximo (nm) & 90,29 & 88,47 & 86,35 & 95,14 & 68,78 & 62,41 & 53,93 & 53,63 \\
\hline Contagem & 100 & 100 & 100 & 100 & 100 & 100 & 100 & 100 \\
\hline
\end{tabular}

A Figura 17 representa o gráfico dos índices de valores de retardos ópticos (RO) onde os valores são expressos em nanômetros $(\mathrm{nm})$, referentes a todos os grupos deste trabalho.

Podemos observar na Figura 17 e na Tabela 1 que os maiores valores de birrefringência estão presentes nos grupos I ao IV, o que supõe que não houve alterações significativas na ordem estrutural da proteína colágeno. Fica evidente que as médias dos valores de birrefringência possuem valores menores nos grupos V ao VIII, o que indica que houve alterações significativas estruturais na proteína colágeno. Essa redução de birrefringência pode ser atribuída à desnaturação do colágeno em temperaturas em torno de 42 a $45^{\circ} \mathrm{C}$. 


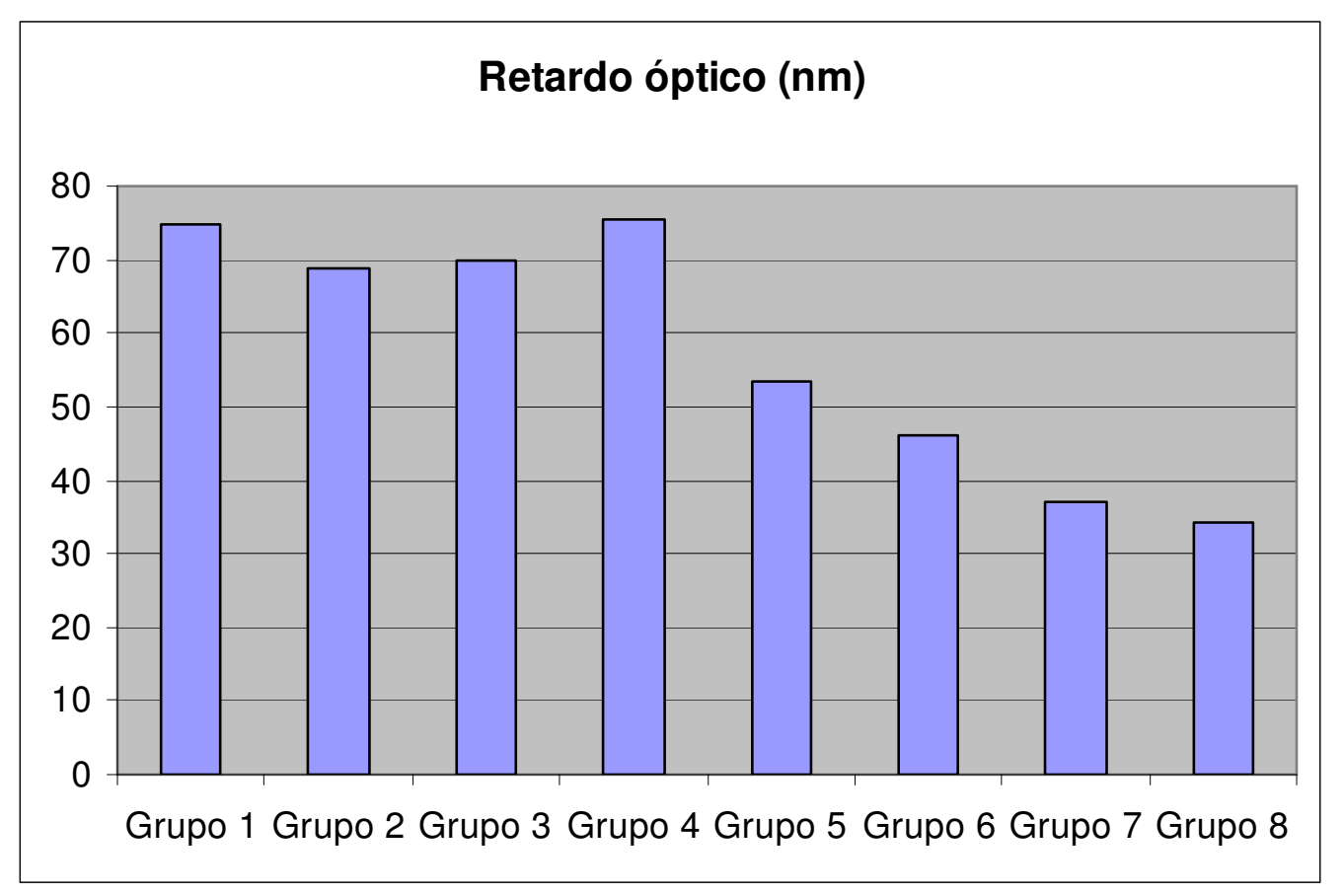

Figura 17. Gráfico da média de valores de retardos ópticos (RO)

Evidencia-se que a desnaturação ocorreu no presente trabalho, pois foi através da análise visual e macroscópica, citadas anteriormente, que em temperaturas mais elevadas ocorreu significativas lesões cutâneas, e maior rigidez tendínea, mas é necessário relatar que a desnaturação ocorreu devido a uma redução dos valores de retardos ópticos (RO), e também por causa da elevada temperatura, como também o tempo de exposição de submersão, por isso, não podemos tirar conclusões quantitativas sobre a redução de birrefringência só em função da temperatura.

A figura 18 representa o gráfico Box Plot das medidas de birrefringência de todos os grupos, ilustrando o comportamento de cada grupo por meio da média, desvio padrão, e erro padrão, portanto através da figura acima o gráfico exibe características dos grupos I ao IV são bem próximos entre si com relação às medidas de birrefringência, tendo uma visualização mais clara das diferenças entre os grupos citados acima, e também fica mais nítido dos grupos V ao VIII, não são tão próximos entre si tendo uma variabilidade muito grande nos valores de birrefringência. 


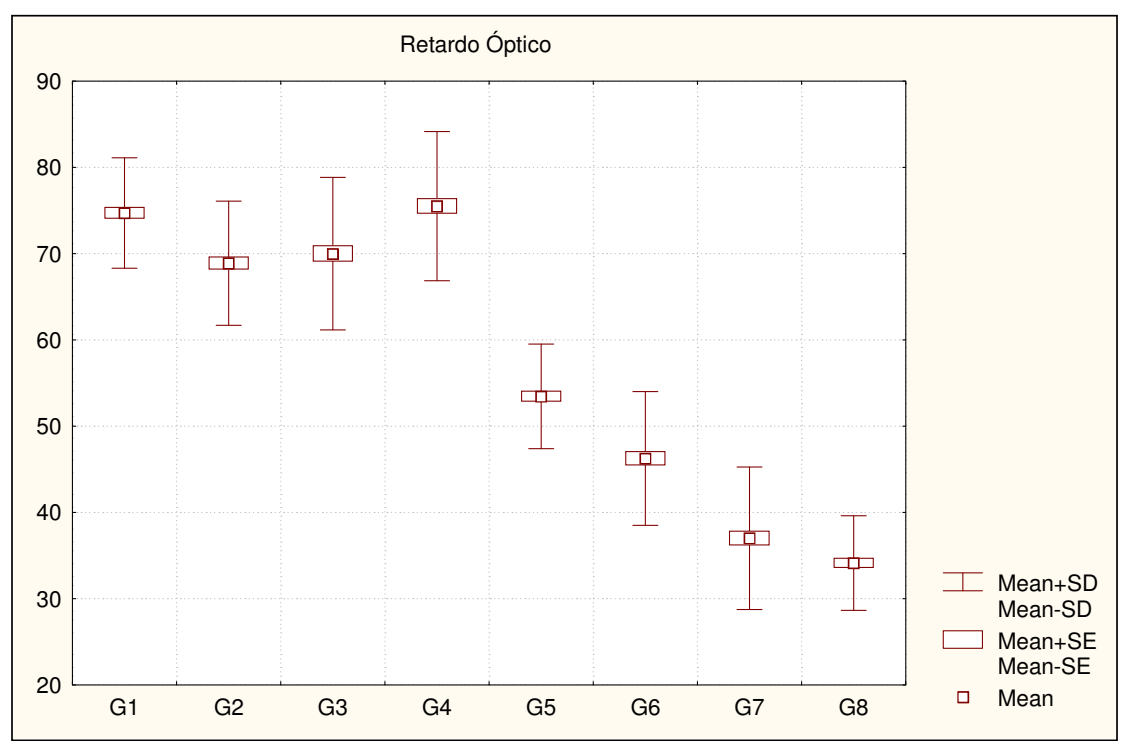

Figura 18. Gráfico Box Plot das medidas de birrefringência.

\section{V.3. Análise qualitativa das medidas de birrefringência}

Nas figuras 19 a 22, fica evidenciado que há uma alta concentração, orientação, estado de agregação e deposição de fibras colágeno, sendo que as imagens foram observadas por meio de microscopia de luz polarizada, com a morfologia do crimp (ondulação, enrugamento) e do brilho altamente característico em estados normais, correspondendo ao eixo longo dos tendões orientados em aproximadamente $45^{\circ}$ em relação aos polarizadores do microscópio, pois é conhecido que nesta posição as fibras de colágeno exibem o maior brilho e conseqüentemente um alto valor de retardos ópticos (RO). 


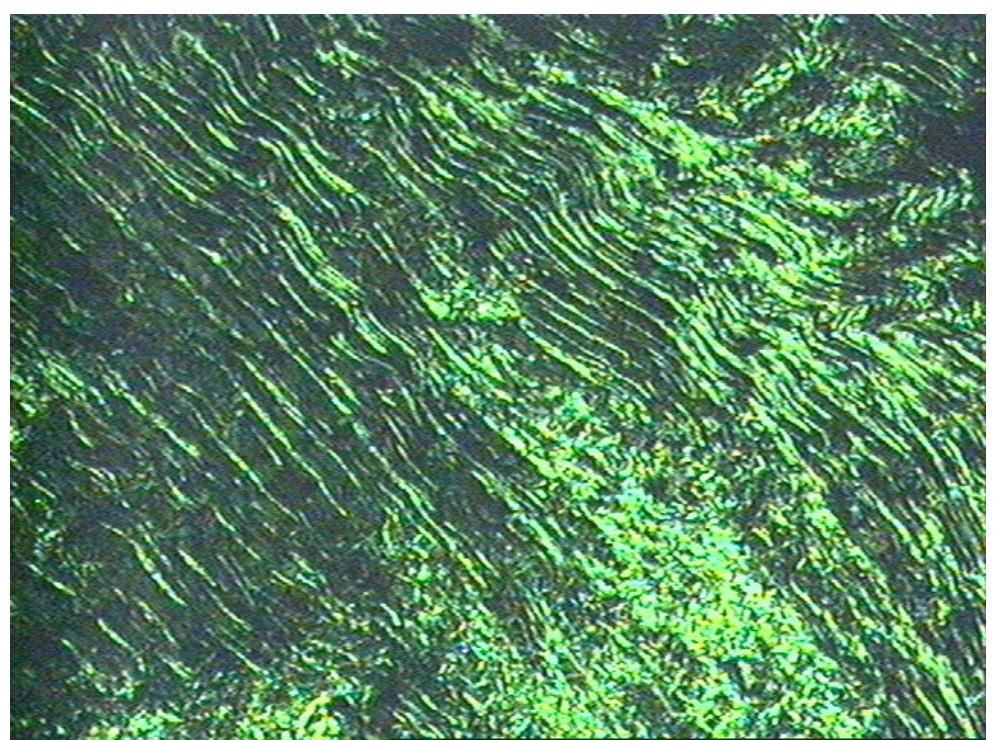

Figura 19. Grupo I, Controle, não submetidos ao experimento, imagens orientadas em aproximadamente $45^{\circ}$ correspondentes a análise qualitativa da birrefringência de forma ou textural através da microscopia de polarização do tendão calcâneo de rato.

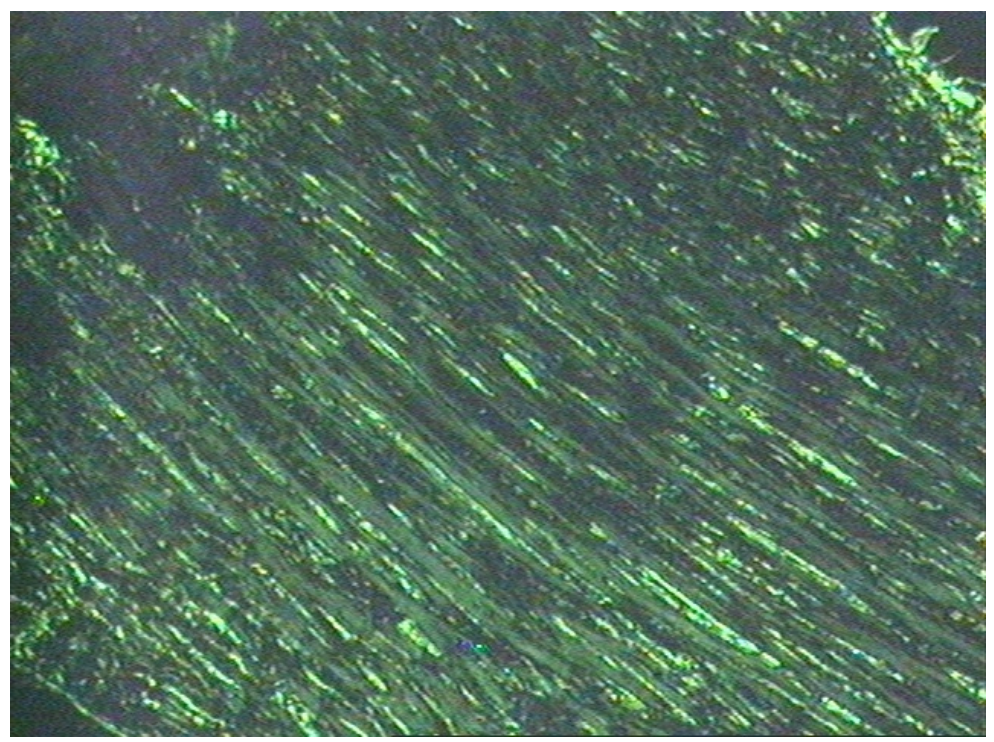

Figura 20. Grupo II $35^{\circ} \mathrm{C}$, imagens orientadas em aproximadamente $45^{\circ}$ correspondentes a análise qualitativa da birrefringência de forma ou textural através da microscopia de polarização do tendão calcâneo de rato, onde os tendões foram submergidos em água aquecida a $35^{\circ} \mathrm{C}$ 


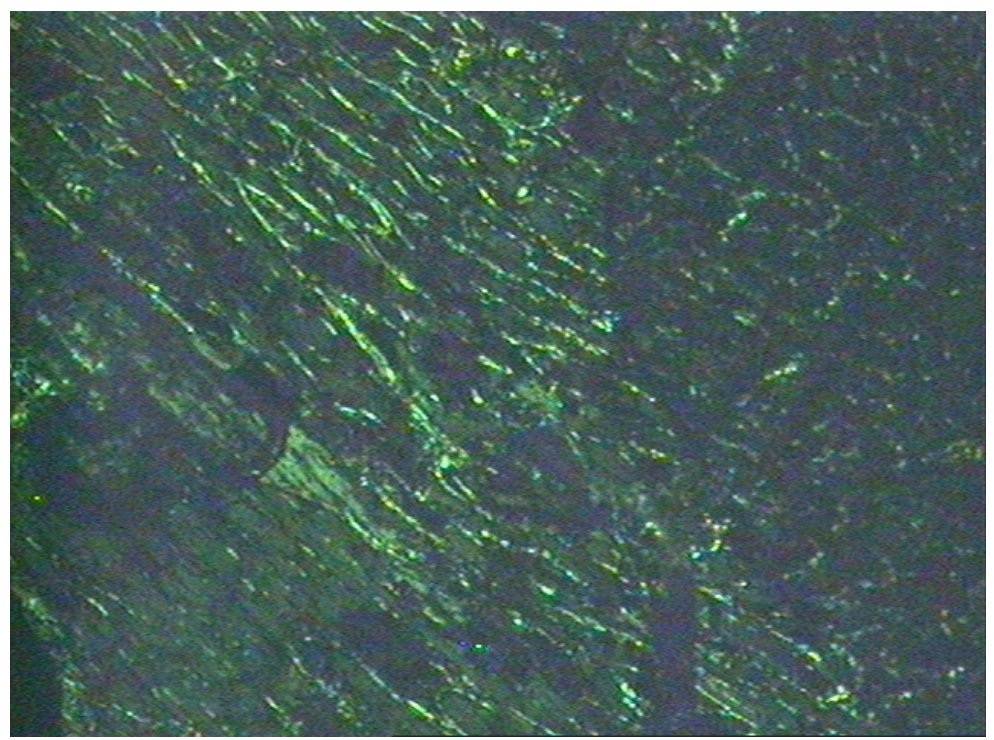

Figura 21. Grupo III $40^{\circ} \mathrm{C}$, imagens orientadas em aproximadamente $45^{\circ}$ correspondentes a análise qualitativa da birrefringência de forma ou textural através da microscopia de polarização do tendão calcâneo de rato, onde os tendões foram submergidos em água aquecida a $40^{\circ} \mathrm{C}$

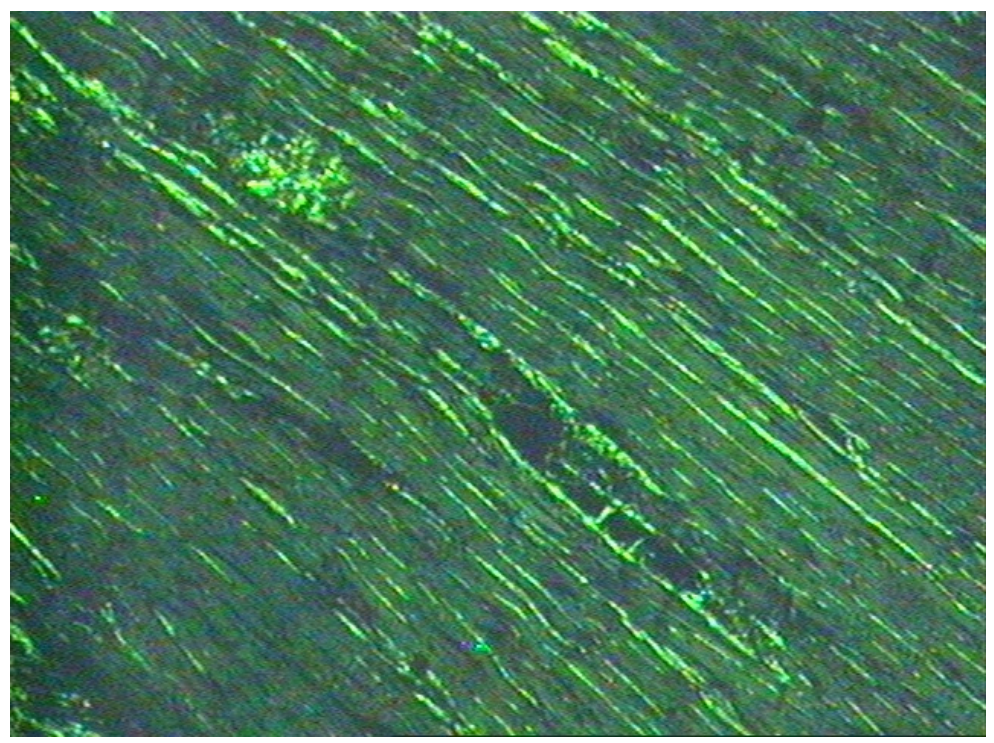

Figura 22. Grupo IV $42^{\circ} \mathrm{C}$, imagens orientadas em aproximadamente $45^{\circ}$ correspondentes a análise qualitativa da birrefringência de forma ou textural através da microscopia de polarização do tendão calcâneo de rato, onde os tendões foram submergidos em água aquecida a $42^{\circ} \mathrm{C}$

Nas figuras 23 a 26, nota-se onde estão as setas vermelhas, áreas altamente desorganizadas onde as fibras perdem a sua continuidade, desestruturação e 
conseqüentemente a desestruturação do colágeno do tendão calcâneo, observadas pela microscopia de birrefringência.

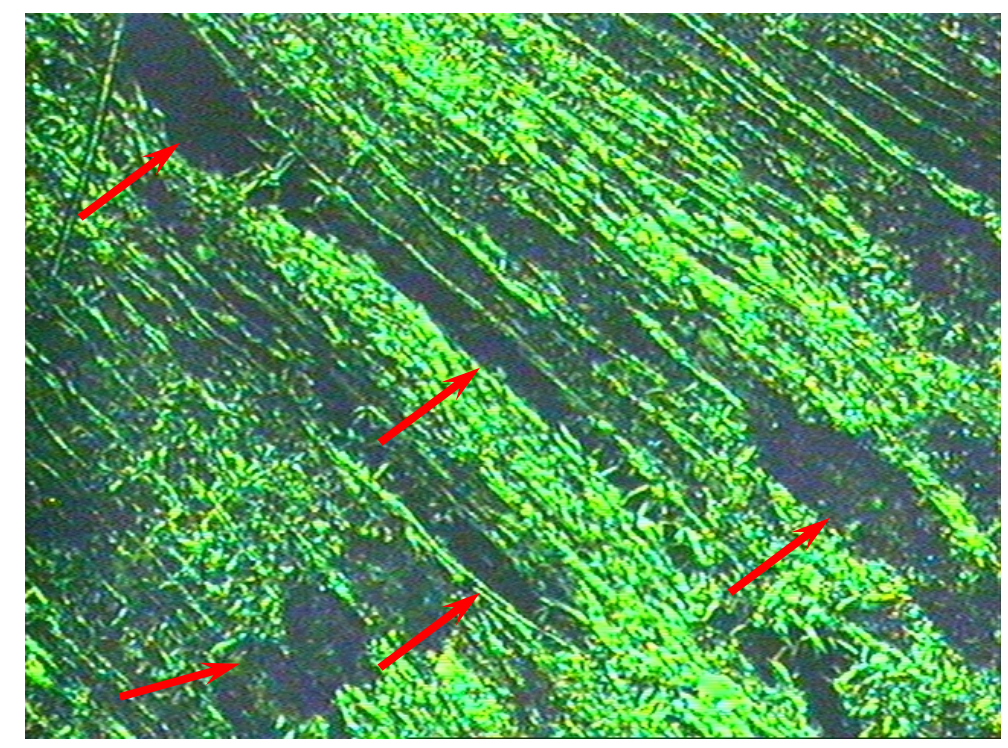

Figura 23. Grupo $\mathrm{V} 45^{\circ} \mathrm{C}$, imagens orientadas em aproximadamente $45^{\circ}$ correspondentes a análise qualitativa da birrefringência de forma ou textural através da microscopia de polarização do tendão calcâneo de rato, onde os tendões foram submergidos em água aquecida a $45^{\circ} \mathrm{C}$

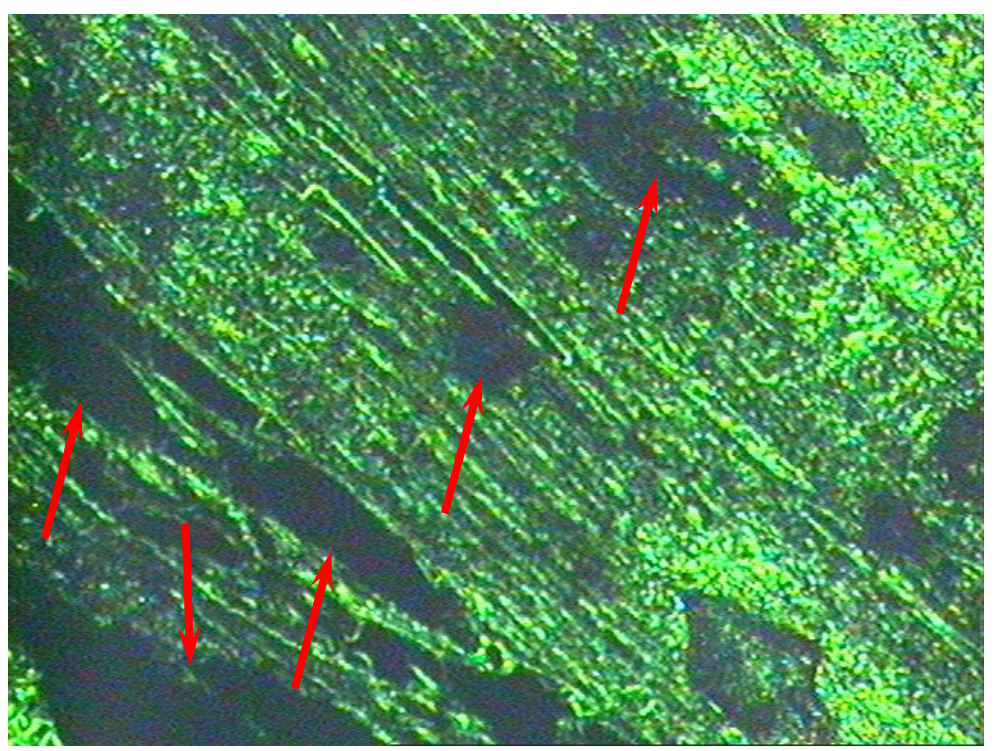

Figura 24. Grupo VI $48^{\circ} \mathrm{C}$, imagens orientadas em aproximadamente $45^{\circ}$ correspondentes a análise qualitativa da birrefringência de forma ou textural através da microscopia de polarização do tendão calcâneo de rato, onde os tendões foram submergidos em água aquecida a $48^{\circ} \mathrm{C}$ 


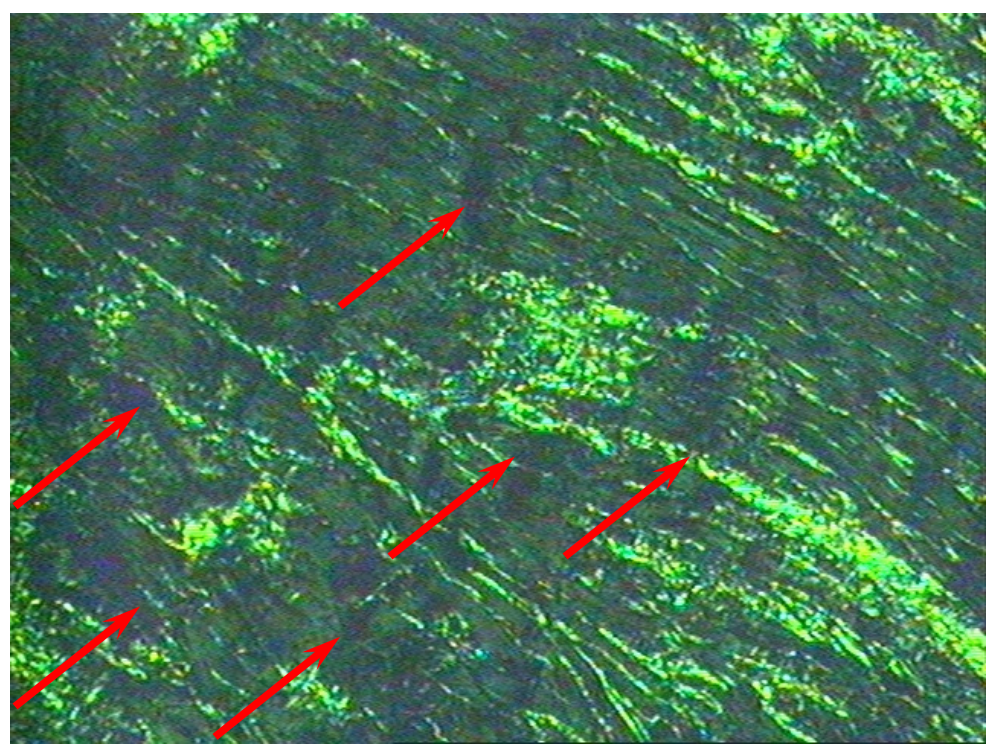

Figura 25. Grupo VII $50^{\circ} \mathrm{C}$, imagens orientadas em aproximadamente $45^{\circ}$ correspondentes a análise qualitativa da birrefringência de forma ou textural através da microscopia de polarização do tendão calcâneo de rato, onde os tendões foram submergidos em água aquecida a $50^{\circ} \mathrm{C}$

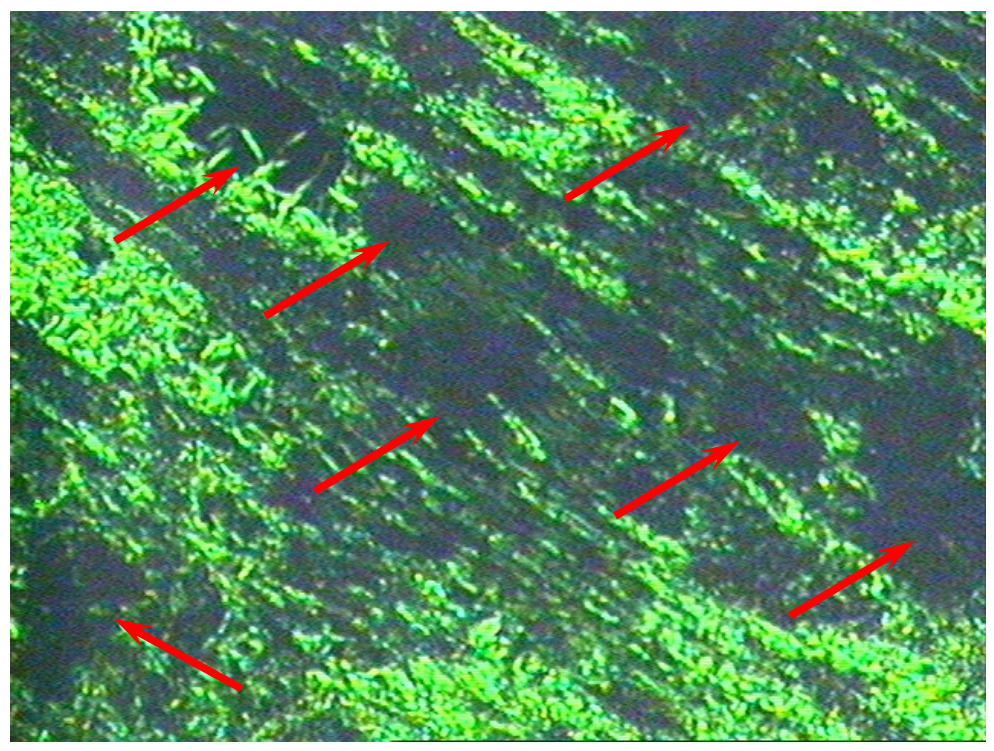

Figura 26. Grupo VIII $55^{\circ} \mathrm{C}$, imagens orientadas em aproximadamente $45^{\circ}$ correspondentes a análise qualitativa da birrefringência de forma ou textural através da microscopia de polarização do tendão calcâneo de rato, onde os tendões foram submergidos em água aquecida a $55^{\circ} \mathrm{C}$

Os grupos I ao IV têm suas médias próximas, o que indica que estão parecidos quanto à ordem estrutural da proteína colágeno. Esse fato repete quando se compara o grupo 
V com VI e o grupo VII com VIII. Os grupos V com VII, V com VIII e VI com VIII têm suas médias distantes, o que indica diferenças na ordem estrutural da proteína.

Os resultados obtidos pela microscopia de polarização sugerem que houve uma diferença estatisticamente muito significativa entre os grupos citados no texto pela alta variação de birrefringência das fibras colágeno quando comparadas com cada grupo isoladamente com o grupo I, II, III e IV, pois com o aumento induzido gradativo das temperaturas em banhos hidrotérmicos ocorreu uma diminuição nos valores de retardos ópticos (RO) o que sugere uma desnaturação do colágeno. Por isso que VIDAL 2003 descreve que o método mais eficaz de se detectar e descrever a orientação das fibras colágeno é através de estudos de propriedades físicas como as medidas de birrefringência.

Os resultados dos animais dos grupos I ao IV indicam que não houve uma variação muito extensa nas medidas de birrefringência das fibras colágeno, ocorrendo uma alta organização e estado de agregação macromolecular, mas o mesmo não confere com os resultados dos animais dos grupos V ao VIII, ficando evidente a existência de alterações morfológicas do colágeno, estado de agregação e alinhamento diminuídos, observado por meio de microscopia de luz polarizada, onde foi possível analisar vários aspectos como os qualitativos da geometria helicoidal, organização superficial das fibras colágeno, e caracterização morfológica.

\section{V.4. Análise qualitativa histológica}

Análises histológicas foram realizadas através de microscopia de luz por meio lâminas histológicas, sob supervisão e auxílio da Prof ${ }^{a}$ Ana Maria Pires Soubhia do Departamento de Patologia e Propedêutica Clínica, na Faculdade de Odontologia de Araçatuba Universidade Estadual Paulista - UNESP, onde as análises histológicas tiveram o 
intuito de analisar reações inflamatórias, definidas por presença de células inflamatórias (mononucleares e polimorfonucleares), fibroblastos e deposição de fibras colágeno, por técnicas de colorações específicas, onde a técnica de coloração por Hematoxilina e Eosina evidencia as alterações das células inflamatórias e a técnica de coloração por Tricrômico de Masson tem preferencialmente a fixação de suas cores, em estruturas musculares e na fibras colágeno.

Através das análises histológicas feitas por microscopia de luz das figuras 27 a 36, percebe-se um alto brilho de coloração, um tecido altamente organizado com as fibras colágeno dispostas longitudinalmente em sentido único, além de fibras musculares e células adiposas, onde as setas pretas indicam uma região com predominância de tecido muscular, as setas lilás uma região com células adiposas e a setas amarelas a prevalência de um tecido com fibras colágeno (tendão), o mesmo não ocorre com as figuras 37 a 42, onde as setas azuis indicam áreas altamente desorganizadas onde as fibras perdem a sua continuidade, desestruturação e conseqüentemente a desestruturação do colágeno do tendão calcâneo, observadas pela microscopia de luz.

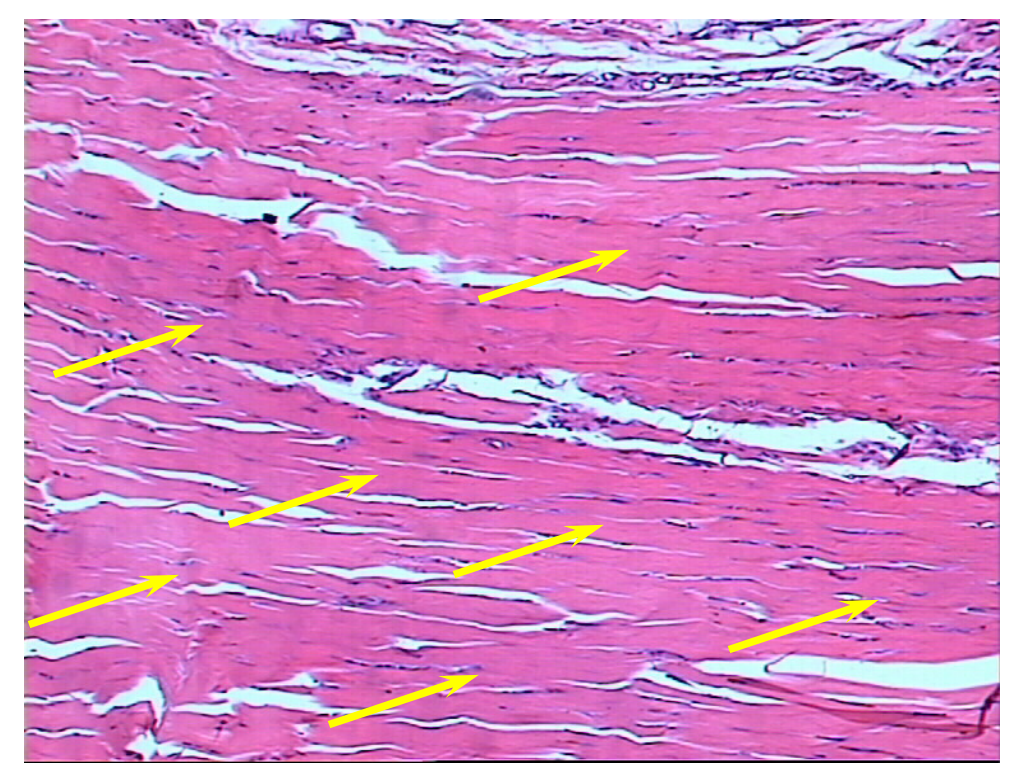

Figura 27. Grupo I, Controle, onde os animais não foram submetidos experimento, aspecto histológico do tendão calcâneo de ratos corados por Hematoxilina e Eosina $10 \mathrm{x}$ 


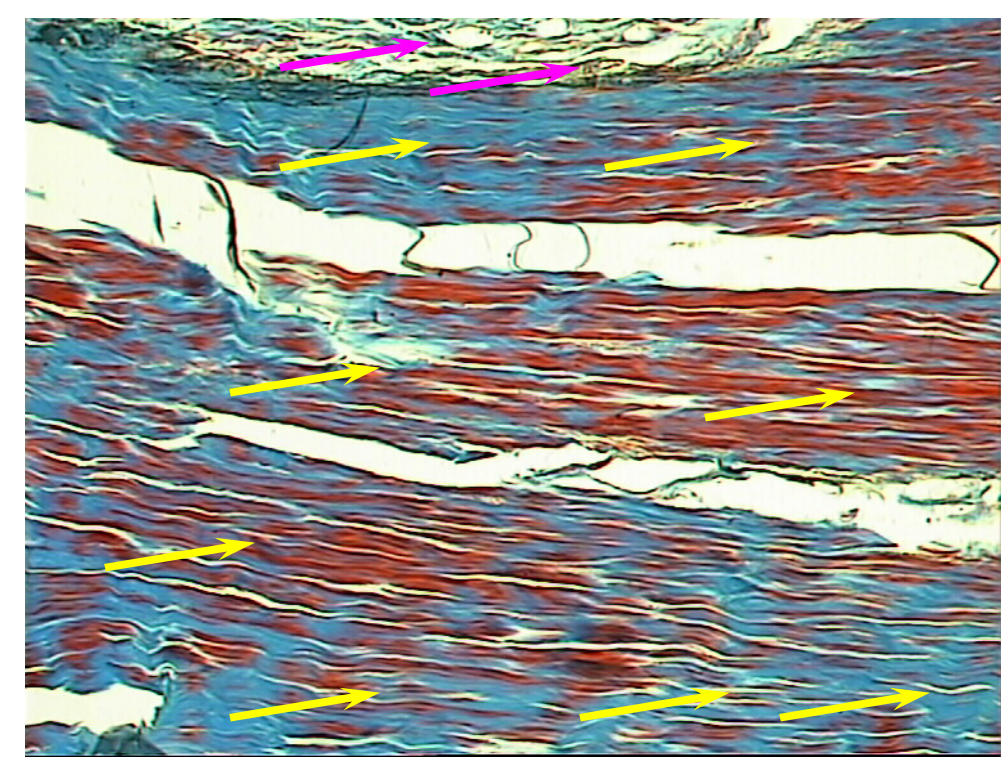

Figura 28. Grupo I, Controle, onde os animais não foram submetidos ao experimento, aspecto histológico do tendão calcâneo de ratos corados por Tricrômico de Masson $10 \mathrm{x}$

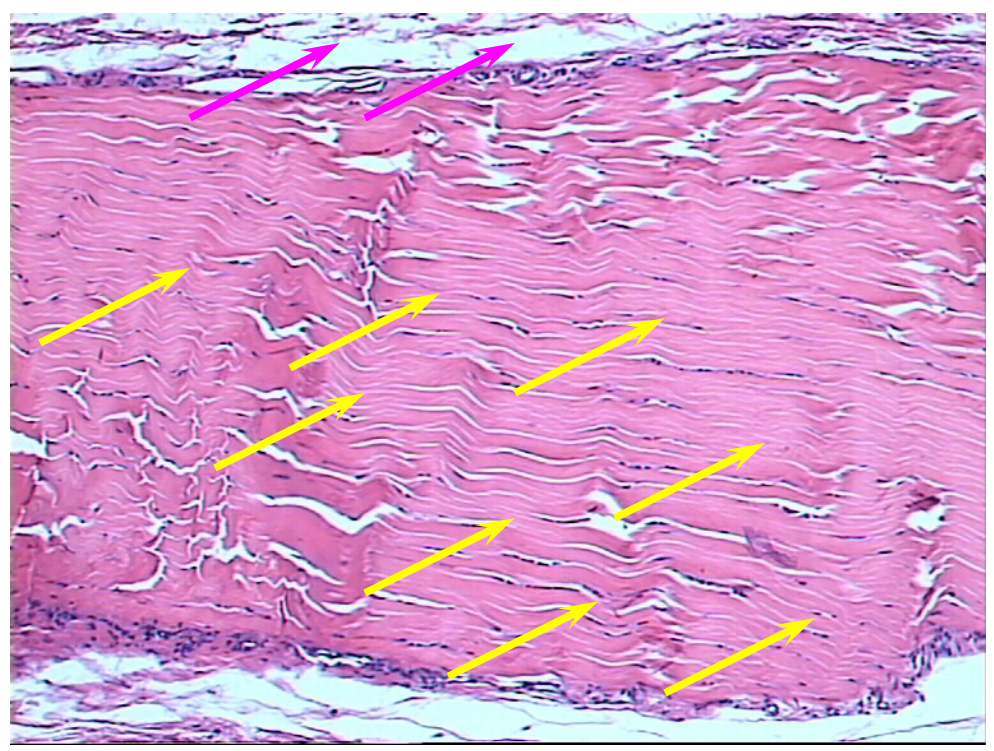

Figura 29. Grupo II $35^{\circ} \mathrm{C}$, aspecto histológico do tendão calcâneo de ratos, onde os tendões foram submergidos em água aquecida a $35^{\circ} \mathrm{C}$, corados por Hematoxilina e Eosina $10 \mathrm{x}$ 


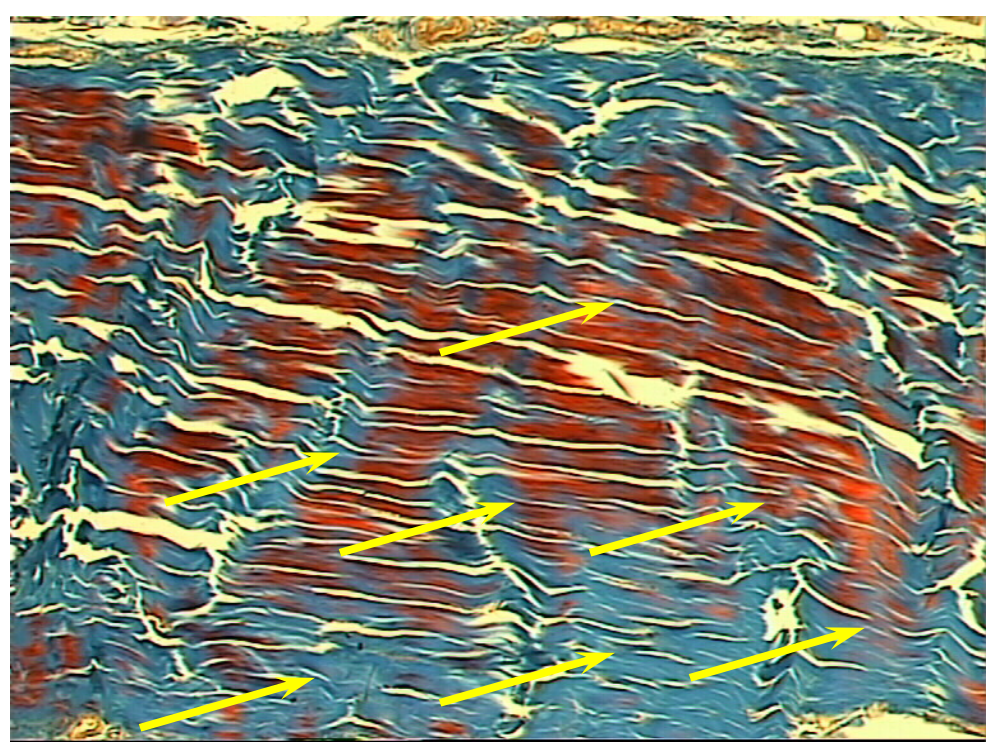

Figura 30. Grupo II $35^{\circ} \mathrm{C}$, aspecto histológico do tendão calcâneo de ratos, onde os tendões foram submergidos em água aquecida a $35^{\circ} \mathrm{C}$, corados por Tricrômico de Masson $10 \mathrm{x}$

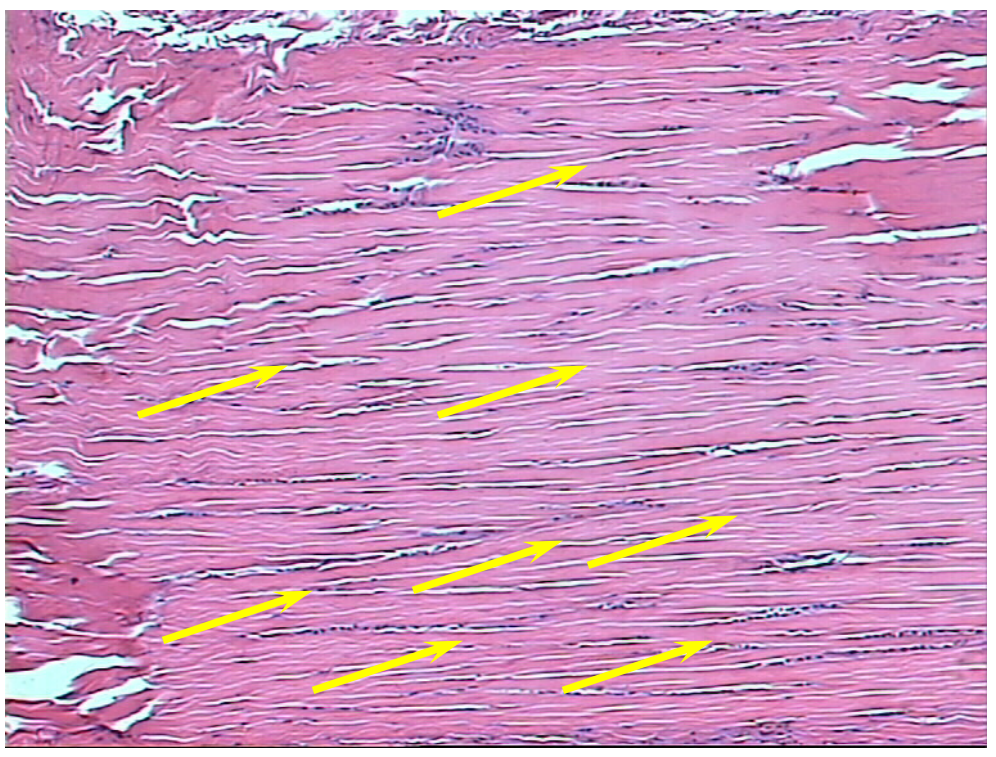

Figura 31. Grupo III $40^{\circ} \mathrm{C}$, aspecto histológico do tendão calcâneo de ratos, onde os tendões foram submergidos em água aquecida a $40^{\circ} \mathrm{C}$, corados por Hematoxilina e Eosina $10 \mathrm{x}$ 


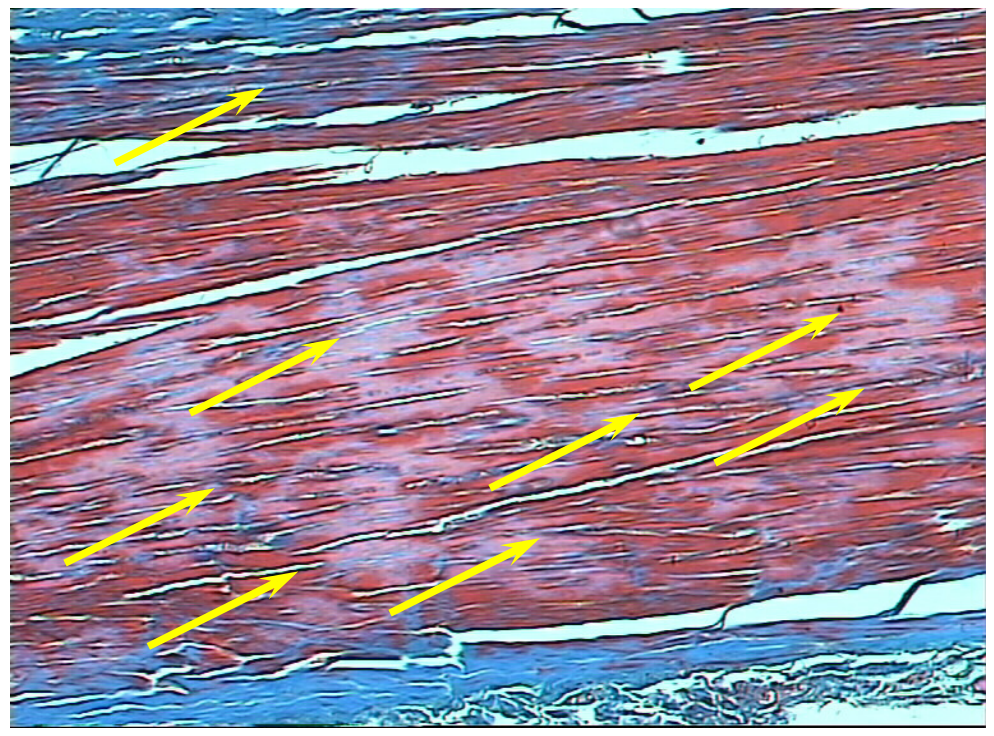

Figura 32. Grupo III $40^{\circ} \mathrm{C}$, aspecto histológico do tendão calcâneo de ratos, onde os tendões foram submergidos em água aquecida a $40^{\circ} \mathrm{C}$, corados por Tricrômico de Masson $10 \mathrm{x}$

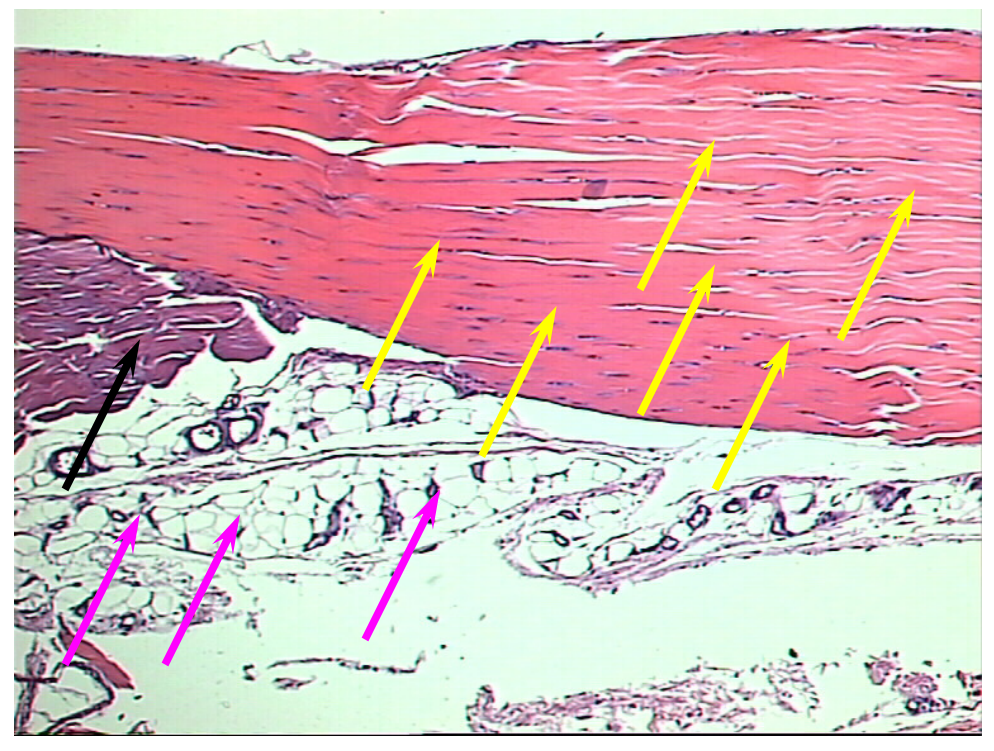

Figura 33. Grupo IV $42^{\circ} \mathrm{C}$, aspecto histológico do tendão calcâneo de ratos, com músculo, onde os tendões foram submergidos em água aquecida a $42^{\circ} \mathrm{C}$, corados por Hematoxilina e Eosina 10x 


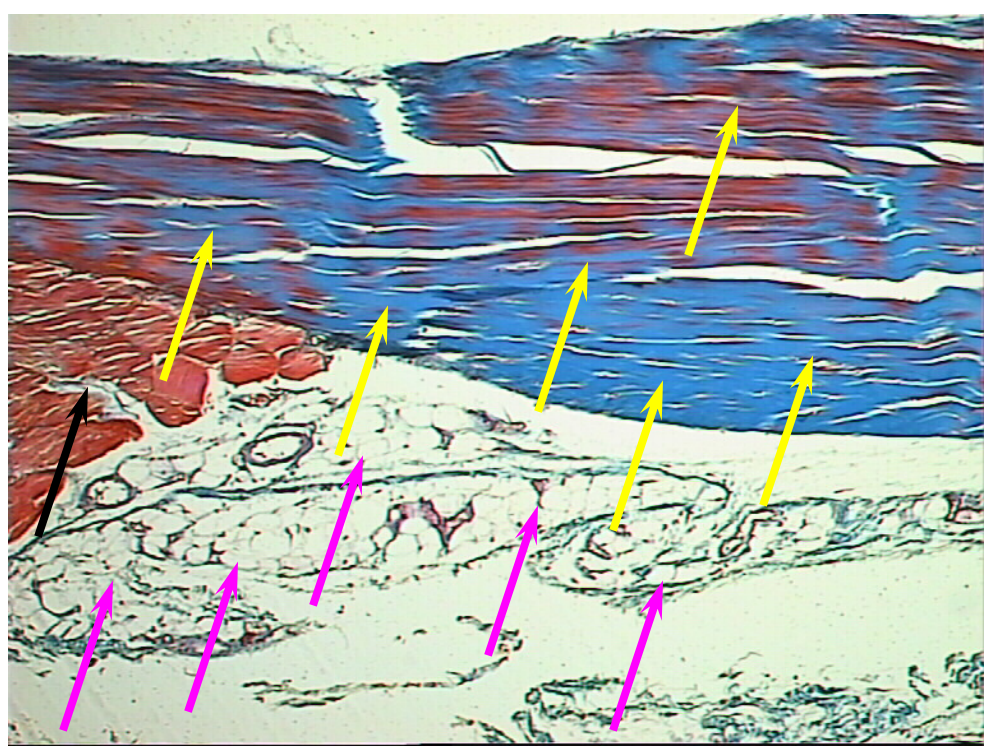

Figura 34. Grupo IV $42^{\circ} \mathrm{C}$, aspecto histológico do tendão calcâneo de ratos, com músculo, onde os tendões foram submergidos em água aquecida a $42^{\circ} \mathrm{C}$, corados por Tricrômico de Masson 10x

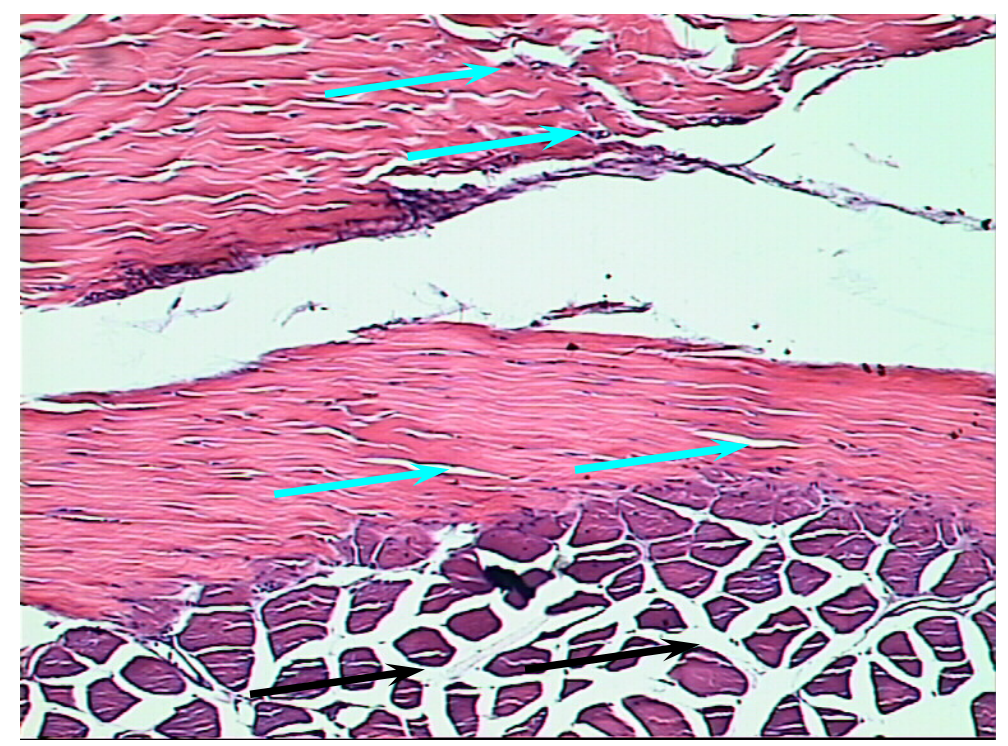

Figura 35. Grupo $\mathrm{V} 45^{\circ} \mathrm{C}$, aspecto histológico do tendão calcâneo de ratos com músculo, onde os tendões foram submergidos em água aquecida a $45^{\circ} \mathrm{C}$, corados por Hematoxilina e Eosina $10 \mathrm{x}$ 


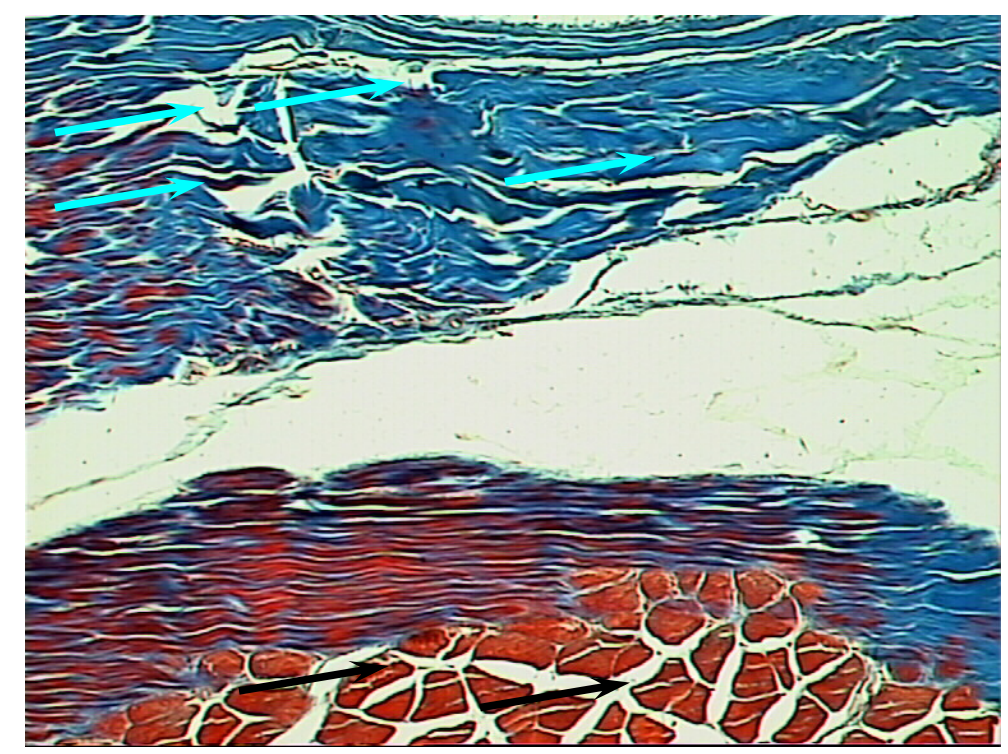

Figura 36. Grupo $\mathrm{V} 45^{\circ} \mathrm{C}$, aspecto histológico do tendão calcâneo de ratos com músculo, onde os tendões foram submergidos em água aquecida a $45^{\circ} \mathrm{C}$, corados por Tricrômico de Masson $10 \mathrm{x}$

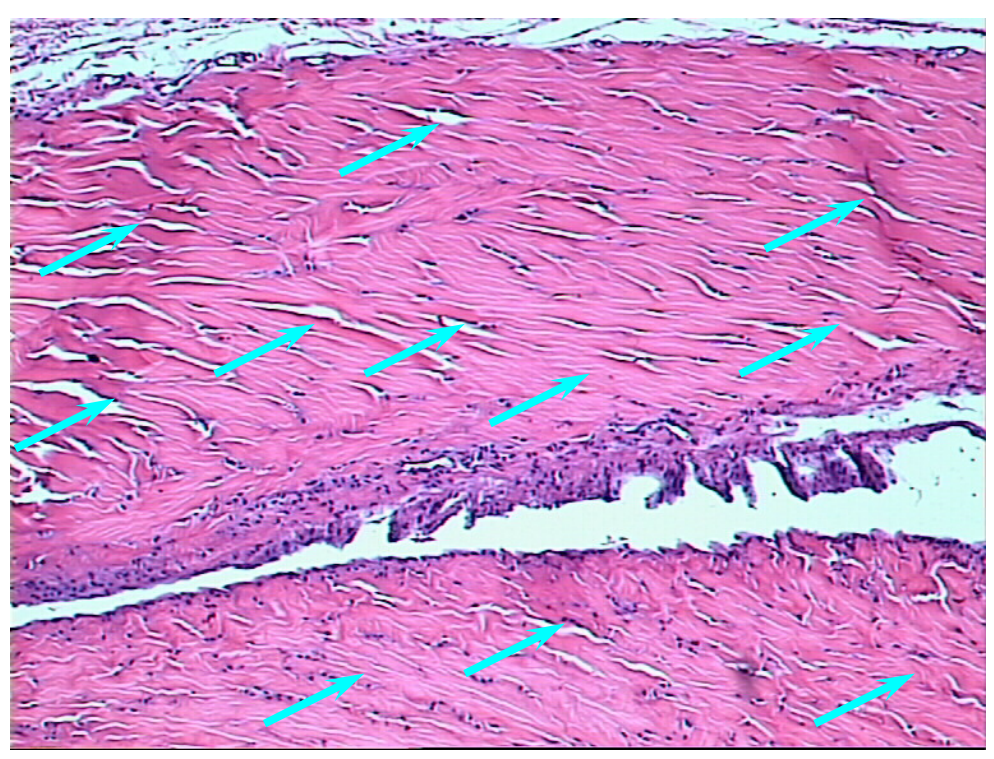

Figura 37. Grupo VI $48^{\circ} \mathrm{C}$, aspecto histológico do tendão calcâneo de ratos, onde os tendões foram submergidos em água aquecida a $48^{\circ} \mathrm{C}$, corados por Hematoxilina e Eosina $10 \mathrm{x}$ 


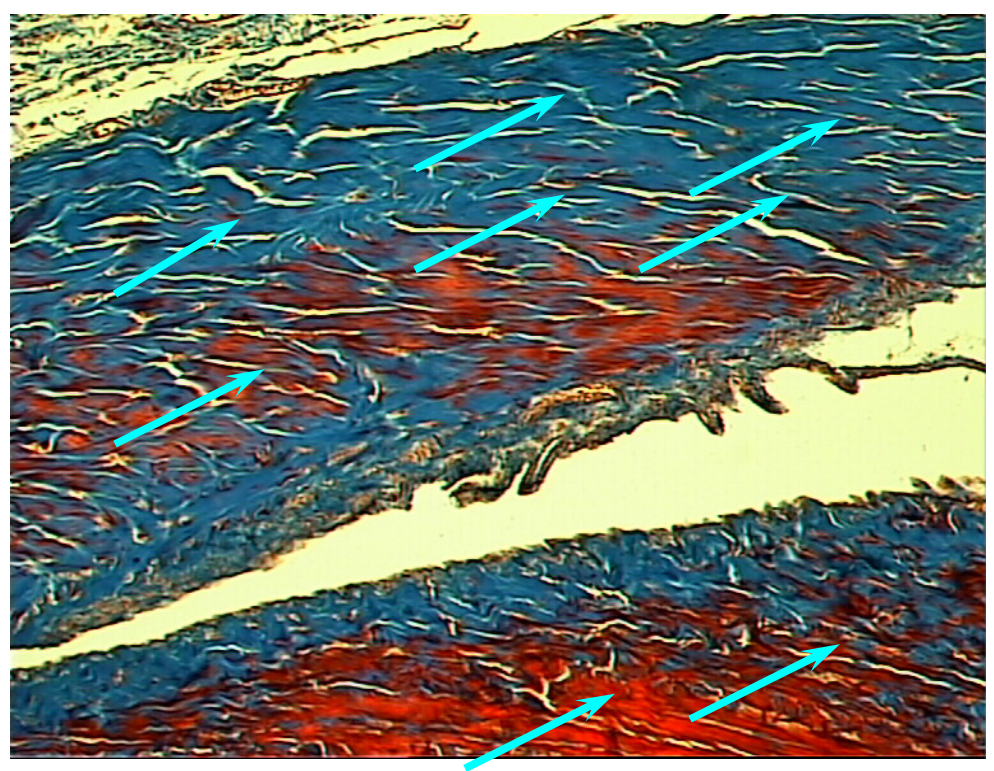

Figura 38. Grupo VI $48^{\circ} \mathrm{C}$, aspecto histológico do tendão calcâneo de ratos, onde os tendões foram submergidos em água aquecida a $48^{\circ} \mathrm{C}$, corados por Tricrômico de Masson $10 \mathrm{x}$

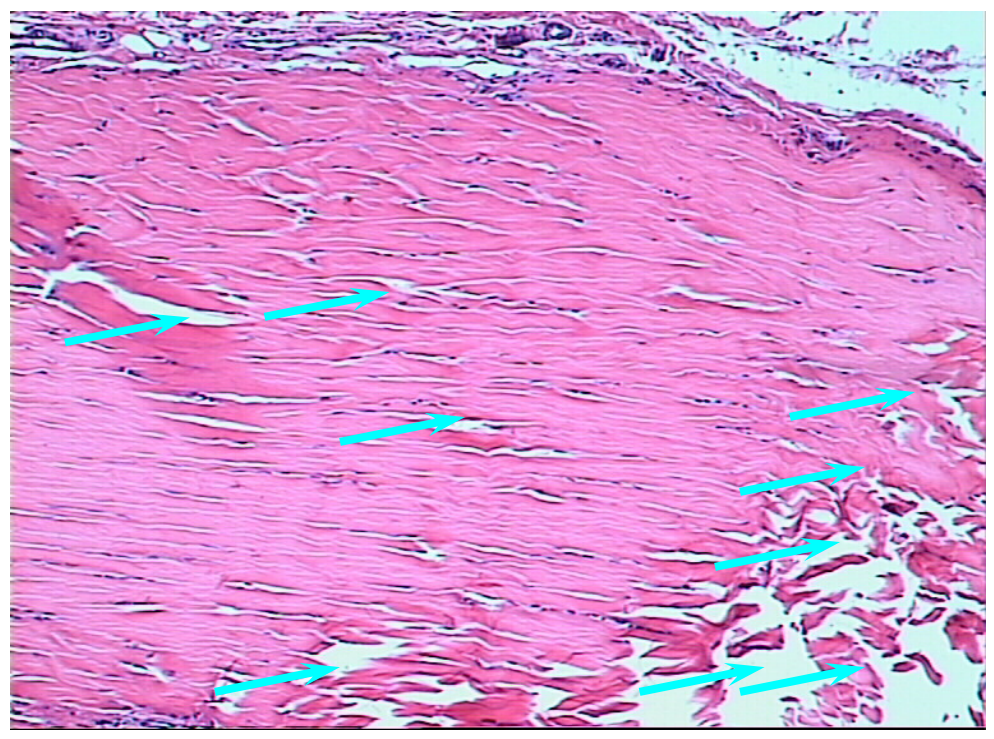

Figura 39. Grupo VII $50^{\circ} \mathrm{C}$, aspecto histológico do tendão calcâneo de ratos, onde os tendões foram submergidos em água aquecida a $50^{\circ} \mathrm{C}$, corados por Hematoxilina e Eosina $10 \mathrm{x}$ 


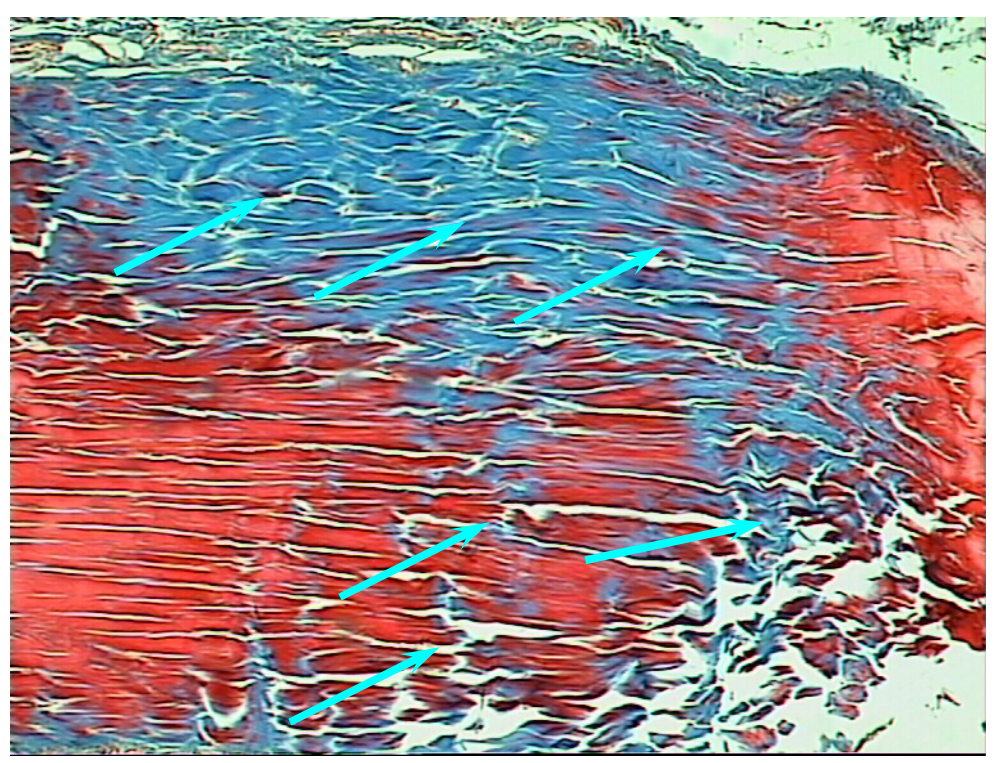

Figura 40. Grupo VII $50^{\circ} \mathrm{C}$, aspecto histológico do tendão calcâneo de ratos, onde os tendões foram submergidos em água aquecida a $50^{\circ} \mathrm{C}$, corados por Tricrômico de Masson $10 \mathrm{x}$

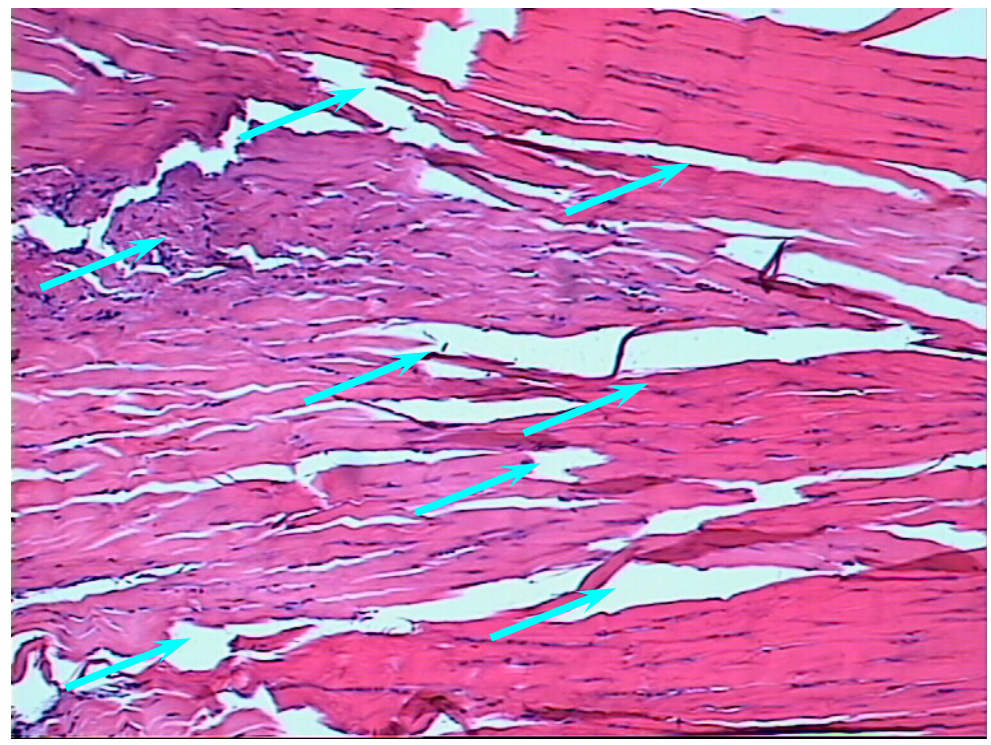

Figura 41. Grupo VIII $55^{\circ} \mathrm{C}$, aspecto histológico do tendão calcâneo de ratos, onde os tendões foram submergidos em água aquecida a $55^{\circ} \mathrm{C}$, corados por Hematoxilina e Eosina10x 


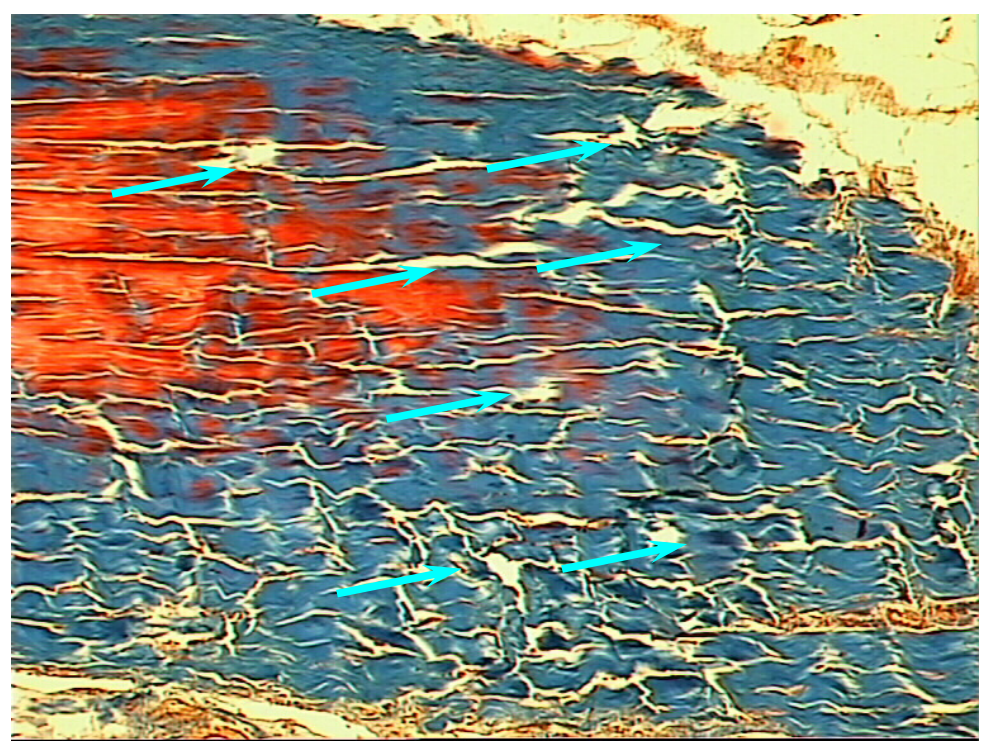

Figura 42. Grupo VIII $55^{\circ} \mathrm{C}$, aspecto histológico do tendão calcâneo de ratos, onde os tendões foram submergidos em água aquecida a $55^{\circ} \mathrm{C}$, corados por Tricrômico de Masson 10x

A análise histológica qualitativa das espécimes retiradas do tendão calcâneo dos ratos, foi realizada utilizando-se as colorações Hematoxilina e Eosina (H.E) e Tricrômico de Masson.

Em linhas gerais as observações feitas à coloração de Hematoxilina e Eosina, observou-se um tecido conjuntivo denso modelado, disposto em fibras conjuntivas largas e quase todas em sentido longitudinal. Incluídas nestes feixes de fibras colágeno pode-se notar células fibroblásticas fusiformes de coloração basofílica dispostas paralelamente ao longo do colágeno e ainda pequenos vasos sangüíneos de permeio a este conjuntivo. Perifericamente a esta fibra colágeno organizada em um sentido único, nota-se uma pequena faixa de tecido conjuntivo frouxo, não modelado, rico em pequenos vasos sangüíneos e ainda células adiposas de tamanho variado dispostas em bloco, interceptadas por feixes conjuntivos vascularizados e presença de tecido muscular que ora se apresenta em feixes longitudinais ora em feixes transversais. 
A coloração especial de Tricrômico de Masson permitiu, em linhas gerais, a visualização dos mesmos feixes paralelos compondo o tendão, porém esta coloração destaca as variações de tonalidade entre azul e vermelho. Desta forma observaram-se fibras coradas em azul o que corresponde à constituição de fibras colágeno da mesma e outras na tonalidade avermelhada o que corresponde ao tecido muscular. Esta coloração permitiu concluir que o tendão calcâneo de ratos é constituído pela junção de tecidos mesenquimais acima citado. Pode-se notar ainda, corados com menor intensidade mas com tonalidade azulada o tecido conjuntivo frouxo periférico com presença de pequenos vasos sangüíneos e células adiposas.

A análise morfológica qualitativa realizada no presente experimento mostrou que as diferenças são muito discretas quando comparamos os animais do grupo I, que não foram submetidos ao experimento, com os animais dos grupos II ao $\mathrm{V}$, que foram submetidos ao experimento. Porém ao analisarmos os tendões calcâneos de ratos submersos em temperaturas mais altas que foram os grupos VI ao VIII, que também foram submetidos ao experimento, começamos a perceber um grau de desarranjo das fibras colágeno e ou musculares, o que é traduzido por perda de continuidade das mesmas que lhe confere a disposição menos homogênea quando comparada com os grupos citados anteriormente.

Portanto, não foi possível estabelecer através da análise qualitativa o componente inflamatório nas espécimes analisadas, atribuídas que a falta de reação inflamatória se deve ao período muito rápido de sacrifício, ou seja, entre a submersão das patas traseiras dos animais e o sacrifício dos mesmos para a tenotomia. Acredita-se que o componente inflamatório estaria presente após 24 horas do experimento realizado na metodologia do presente trabalho.

As discretas alterações morfológicas observadas ao aquecimento nos grupos VI, VII e VIII, podem ter sido pelo início da desnaturação das proteínas do colágeno denso, as quais ocorreram apenas sob temperaturas elevadas. Talvez uma das manifestações destas alterações seja a perda de afinidade tintorial observada na coloração do Tricrômico de Masson 
associada às quebras da integridade do colágeno denso observadas na coloração de Hematoxilina e Eosina. Isto pode ser observado nas figuras 37 a 42, onde se vê um clareamento nas imagens, dando a impressão de opacas, uma não homogeinidade, onde o tecido apresenta-se de uma forma espaçado e uma interrupção ao longo de seu trajeto longitudinal, principalmente nas figuras 39, 40, 41 e 42, isto também se confere não só para tecidos tendíneos, mas também para os tecidos musculares.

\section{V.5. Análises da calorimetria exploratória diferencial (DSC)}

O colágeno no tendão calcâneo é do tipo I assumindo a configuração da hélice tripla no espaço extracelular. As três cadeias polipeptídicas são estabilizadas por ligações inter e intramoleculares. Com o aquecimento, após um certo valor de temperatura, as ligações intramoleculares se quebram e a proteína passa por uma transição de fase, mudando de uma estrutura cristalina para uma estrutura randômica, desordenada. A desnaturação térmica é um processo endotérmico e, portanto, o DSC pode ser usado para correlacionar a exposição térmica com o resultante grau de desnaturação.

A figura 43 mostra as curvas DSC obtidas para os tendões que foram submetidos “in vivo" após os procedimentos experimentais à diferentes temperaturas. 


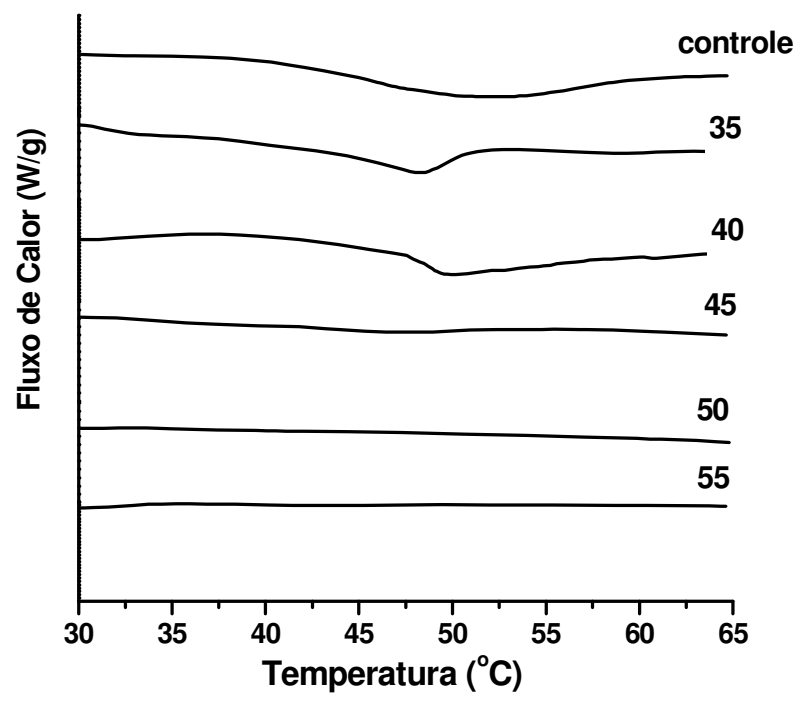

Figura 43. Curvas de DSC para os tendões calcaneos de ratos submetidos à diferentes temperaturas

Observa-se que as curvas referentes o grupo controle e as temperaturas de 35 e $40^{\circ} \mathrm{C}$ apresentam uma transição em torno de $47^{\circ} \mathrm{C}$, que pode ser atribuída à desnaturação do colágeno que constitui o tendão calcâneo.

Nas curvas referentes a 45,50 e $55^{\circ} \mathrm{C}$, já não é possível observar essa transição, indicando que o material já se encontra desnaturado, pois gelatina não apresenta transição de fase, no intervalo de temperatura estudada de 30 a $55^{\circ} \mathrm{C}$.

Estes resultados estão bem correlacionados com o já observado nas análises histológicas e de birrefringência, onde os efeitos da temperatura são observados para temperaturas maiores que $45^{\circ} \mathrm{C}$. 


\section{CONCLUSÃO}

Com base no resultado dos experimentos, por meio de análises de birrefringência, histológicas e calorimétricas foi possível observar nos grupos V, VI, VII e VIII, a ocorrência de alterações na estrutura do tecido após a exposição dos tendões calcâneos de rato em temperaturas que variaram de 45 a $55^{\circ} \mathrm{C}$.

Elevações térmicas do tendão calcâneo superiores a $45^{\circ} \mathrm{C}$ sugerem alterações significativas na estrutura terciária do colágeno presente no mesmo, provocando desnaturação em sua conformação nativa, resultando em perda da função biológica específica.

Valores de retardo óptico (RO), as curvas DSC e as lâminas histológicas mostraram alterações significativas para temperaturas superiores a $45^{\circ} \mathrm{C}$. 


\section{REFERÊNCIAS BIBLIOGRÁFICAS}

ABRAMSON, D. I. (1967). Comparison on of wet and dry heat in raising temperature tissue. Achieves of Physical Medicine in Rehabilitation, v. 46, p. 216-244.

AKSAN, A.; ARNOCZKY, S.P. (2000). Thermal modification of connective tissue: basic science considerations and clinical implications. American Academy of Orthopaedic Surgeons, v. 8, n. 5, p305-313.

ALTER, M. J. (2001). Ciência da Flexibilidade. 2 ed. São Paulo: Artmed.

ANDREWS, J. R.; HARRELSON, G. L.; WILK, K. E. (2000). Reabilitação Física das Lesões Desportivas. 2 ed. Rio de Janeiro: Guanabara Koogan, cap. 6, p.107.

BIRK, D. E.; ZICBAND, E. I.; WOODRUF, S.; WINKELMANN, D. A.; TRELSTAD, R. L. (1997). Collagen fibrilogenesis in situ: fibril segments become long fibrils as the developing tendon matures. Developmental Dynamics, v. 208, p. 291-298.

BOER, J. F.; SRINIVAS, S.M.; MALEKAFZALI, A.; CHEN, Z.; NELSON, J.S. (1998). Imaging thermally damaged tissue by polarization sensitive optical coherence tomography. Optics Express., v. 3, p.212-218.

BOYKIN, J. V.; MOLNAR, J. A. (1992). Burn scar and skin equivalents, in Cohen I. K.; DIEGELMANN, R.F.; LINDBLAD, W. J. (eds): Wound Healing: Biomechanical and Clinical Aspects. Philadelphia: WB Saunders. P. 523-540.

BRANDTS, J. F. (1969). Conformational transitions of proteins in water and in aqueous mixtures. In: Structure and Stability of Biological Macromolecule. New York: Marcel Dekker.

CARLSTEAD. C.; A. (1987). Mechanical and chemical factors in tendon healing: Effects indomethacin and surgery in the rabbit. Acta Orthopaedic Scandinavia, v. 58, n. 224, p. 1-75.

CHEN, S. S.; WRIGHT, N. T.; HUMPHREY, J.D. (1997). Heat-induced changes in the mechanics of collagenous tissue: isothermal free shrinkage. Journal of Biomechanics Engineering, v.4, p.372-378.

CHIMICHI, D.; SHRIVE, N.; FRANK, C.; MARCHUK, L.; BRAY, R. (1992). Water content alters viscoelastic behaviour of the normal adolescent rabbit medial collateral ligament. Journal of Biomechanics, v.30, p. 831-837.

CONTRAN, R. S.; KUMAR, V.; ROBBINS, S. L. (1996). Robbins Patologia Estrutural e Funcional. 5 ed. Guanabara Koogan: Rio de Janeiro, p-353. 
CORMACK, D. H. (2003). Fundamentos de Histologia, $2^{\circ}$ ed. Rio de Janeiro, Guanabara Koogan , cap 8, p. 141-142.

CULAW, E. M.; CLARK, C. H.; MERRILEES, M. J. (1999). Connective tissue: Matrix composition and its relevance to physical therapy. Physical Therapy, v. 79, n. 3, p. 308-319.

CURRIER, D. P.; NELSON, R. M. Dynamics of human biologic tissue. (1992). In: ENWEMEKA, C. S.; SPIEHOLZ, N. I. Modulation of tendon grouth and regeneration by electrical fields and currents, Philadelphia, F. A. Davis Company, cap. 3, p. 231-254.

CUTANEOUS STIMULATION. Disponível na Internet via http://www.stat.washington. Edu/TALARIA/LS4.2.1.html.Capturado em dez 2000.

DU BOIS, E. F. (1951). The Many different temperatures of the human body and its parts. West. J. Surg, cap.59, p. 476.

ENOKA, R. M (2000). Bases Neurociências da Cinesiologia, $2^{\circ}$ ed, Sào Paulo, Manole, p.123

ENWEMEKA, C. S. (1989a). Inflammation, cellurarity, and fibrillogenesis in regeneration tendon: Implications for tendon rehabilitation. Physical Therapy, v. 69, p. 816-825.

ENWEMEKA, C. S. (1989b). The effects of therapeutic ultrasound on tendon healing a biomechanical study. American Journal of Physical Medicine and Rehabilitation, p. 283-287.

ENWEMEKA, C. S.; SPIEHOLZ, N. I.; NELSON, A. J. (1988). The effect of early functional activities on experimentally tendomized achilles tendons in rats. American Journal of Physical Medicine and Rehabilitation, v. 67, n. 6, p. 264-269.

Estructura Del Colágeno. Disponível em: http://www.cueronet.com/tecnica/colageno.htm Acesso em: 23 de julho 2006.

EXICOR. Disponível em: http://www.exicor.com/birefringence

FALK, D. S.; BRILL, D. R.; STORK, D. G. (1986). Scattering and polarization. In: Seeing the Light: Optics in Nature, Phitografy, Color, Nison and Holography. New York: HARRER \& ROW Publisher, Holography, cap.13, p. 336-347.

FANTON, G. S. (1998). Arthroscopic electrothermal sugery of the shoulder. Operative Thechniques Sports Medicine. cap. 6, p. 139-146.

FANTON, G. S; WALL. M. S; MARKEL, M. D. (1998). Electrothermally-assisted capsule shift (ETAC) procedure for shoulder instability, in The Science and Applications of Electro Thermal Arthroscopy. Menlo Park, Calif: Oratec Interventions.

GATNER, L. P.; HIATT, J. L. (2003). Tratado de Histologia, $2^{\circ}$ ed, Rio de Janeiro, Guanabara Koogan, cap. 1, p. 1-2. 
PITELLA FILHO, B. G.; J. E. H.; PEREIRA, F. L.; BAMBIRRA, E. A.; BARBOSA, A. J. A. (1994). Bogliolo Patologia 5 ed. Rio de Janeiro: Guanabara Koogan.

GRANT, M. E.; PROCKOP, P. D.; DARWIN, J. (1972). The biosynthesis of collagen. New England Journal of Medicine, p. 284-286.

HAUT, T.; L.; HAUT, R.; C. (1997). The state of tissue hydration determines the strain-rate sensitive stiffness of human patellar tendon. Journal of Biomechanics, v. 30, p. 79-81.

HAYASHI, K.; MARKEL, M. D. (2001). Thermal capsulorrhaphy treatment of shoulder instability: basic science. Clinical Orthopaedics and Related Research 390, p. 59-72.

HAYASHI, K.; MASSA, K. L.; THABIT, G. III. (1999). Histologic evaluation of the glenohumeral joint capsule after the laser assited capsular shift procedure for glenohumeral intability. American Journal of Sports Medicine. cap.27, p. 162-167.

HAYASHI, K.; THABIT III, G.; MASSA, K. L.; BOGADANSKE, J. J.; COOLEY, A. J.; ORWIN, J. S.; MARKEL, M. D. (1997a). The effect of thermal heating on the length and histologic properties of the glenohumeral joint capsule. American Journal of Sports Medicine. cap.1, p. 107-112.

HAYASHI, K.; NIECKARZ, J. A.; THABIT, G. III.; BOGADANSKE, J. J.; COOLEY A. J. MARKEL, M. D. (1997b). The effect of nonablative laser energy on joint capsular properties: An in vivo rabbit study using a holmium: YAG laser. Laser Surgery Medicine. cap. 20, p. 164-171.

HAYASHI, K.; THABIT, G. III.; MASSA, K. L. (1997c). The effect of thermal heating on the length and histologic properties of the glenohumeral joint capsule. American Journal of Sports Medicine. cap. 25, p. 107-112.

HAYASHI, K.; MARKEL, M. D; THABIT, G. III; BOGADANSKE, J. J.; THIELK. R. J. (1995). The effect of nonablative laser energy on joint capsular properties: An in vitro mechanical study using a rabbit model. American Journal of Sports Medicine. cap. 23, p. 482-487.

HECHT, P.; HAYASHI, K.; LU, Y.; FANTON, G. S.; THABIT III, G.; VANDERBY, Jr., R.; MARKEL, M. D. (1999). Monopolar radiofrequency energy effects on joint capsular tissue: potential treatment for joint instability an in vivo mechanical, morphological, and biochemical study using an ovine model. American Journal of Sports Medicine, v. 6, p. 761771 .

HECHT, E. (1991). Óptica. Tradução e Prefácio: Rebordão, J. M. N. V. 2 ed: Fundação Calouste Gubelkain, cap. 8, p. 282-346.

HÖRMANN, H.; SCHLEBUSCH, H. (1971). Reversible and irreversible denaturation of collagen fibers. Biochemistry, cap. 10, p. 932-937. 
JOZSA, L.; KANNUS, P. (1997). Human tendons. United States of America: Human Kinects.

JUNQUEIRA, L. C.; CARNEIRO. (2004). Histologia Básica, Rio de Janeiro, Guanabara Koogan, cap 5, p. 92.

JUNQUEIRA, L. C.; CARNEIRO, J.; LONG, J. A. (1989). Basic Histology. (6 th ed). Los Altos, CA: Lange Medical.

KAUL, M. P.; HERRING, S. A. (1994). Superficial heat and cold. The Physian and Sports Medicine. v. 22, n. 12, p. 65-74.

KHAN, K.; M.; COOK, J. L.; BONAR, F.; HARCOURT, P.; ASTROM, M. (1999). Histopathology of common tendinophaties. Injury Clinic, v. 27, n. 6, p. 393-408.

KTICHEN, S.; BAZIN, S. (1998). Eletroterapia de Clayton. 10 ed. São Paulo: Manole.

KOTTKE, F. J.; STILLWELL, G. K.; LEHMANN, J. F. (1984). Krusen: Tratado de medicina física e reabilitação. 3 ed. São Paulo: Manole.

KRONICK, P.; MALEEF, B; CARROLL, R. The locations of collagens with different thermal stabilities in fibrils of bovine reticular dermis. Connective Tissue Research, v. 2, p. 123-134.

LEHMAN, J. F.; De LATEUR, B. J. (1988). Therapeutic heat. In: Lehmann, J. F. Therapeutic Heat and Cold. Baltimore, Williams \& Wilkins, 1982.

LEHMAN, J. R. (1974). Therapeutic heat and cold. Clin Orthop. p. 207.

LEHMAN, J. F. et al. Temperature distributions in the human thigh, produced by infrared, hot pack and microwave applications. Arch. Phys. Med. v. 47, p. 291-299, 1966.

LEHNINGER, A. L.; NELSON, D. L.; COX, M. M. (2000). Princípios de Bioquímica. 2 ed. São Paulo: Sarvier.

LEHNINGER, A. L. (1976). Bioquímica. 2 ed. São Paulo: Edgard Blücher.

LIANZA, S. Medicina de Reabilitação. 3 ed. Rio de Janeiro: Guanabara Koogan, 2001.

LUESCHER, M.; RUEFF, M.; SCHINDLER, P. (1974). Effect of hydration upon the thermal stability of tropocollagen and its dependence on the presence of neutral salts. Polymers, $\mathrm{v}$. 13 , p. $2489-2503$.

MACHADO, C. M. (1991). Eletroterapia Prática. São Paulo: Com. E. Reprise.

MAITLAND, D. J.; WALSH, J.T. (1997). Quantitative measurements of linear birrefringence during heating of native collagen. Lsers Surgr. Med, v. 20, p.310-318. 
MELLO, M. L.; GODO, C. VIDAL, B. C.; ABUJADI, J. M. (1975). Changes in Macromolecular Orientacional on Collages Fibers During The Process of Tendon Repair in the Rat. Ann. Histochim, v.20 p. 145-152.

MICHLOVITZ, S. (1986). Thermal agents in rehabilitation. Philadelphia, F. A, Davis Company.

MILES, C.A.; GHELASHVILI, M. (1999). Polymer-in-a-box mechanism for the thermal stabilization of collagen molecules in fibers. Biophysical Journal, v. 6, p. 3243-3252.

MILES, C.A.; BURJANADZE, T. V.; BAILEY, A. J. (1995). The kinetics of the thermal denaturation of collagen in unrestrained rat tail tendon determined by differential scanning calorimetric. Journal of Biologic, p. 437-446.

MOUNTCASTLE, V. B. (1974). Fisiologia Médica. 13 ed. vol. 2, Rio de Janeiro: Guanabara Koogan.

NARDY, J. A.(2006).Disponívelem:<http://www.rc.unesp.br/gce/petrologia/nardy/motipoext. html > Acesso em: 23 de julho 2006.

NIMNI, M. E.; HARKNESS. R. D. (1988). Molecular structures and functions of collagen. In: NIMNI, M. E. Collagen. CRC Press, Inc. Boca Raton, Flórida, p. 01-77.

OKUYAMA, K; OKUYAMA, K; ARNOTT, S; TAKAYANAGI; M ; KAKUDO; M. (1981). Crystal and molecular structure of a collagen-like polypeptide (Pro-Pro-Gly). Journal of Molecular Biology,v.152, p.427

PARIZOTTO, N. A. (1998). Ação do Laser Hélio-Neônio sobre o Processo de Reaparo Tecidual: Um Estudo do Colágeno por Microscopia Eletrônica de Varredura, Microscopia de Varredura, Microscopia de Força Atômica e Espectroscopia por Infravermelho. Tese de Doutorado, Faculdade de engenharia Elétrica e de Computação, Universidade Estadual de Campinas.

PIMENTEL, E. R. (1981). Form Birefringence of collagen boundless. Acta Histochem Citochem, v.14, n.1, p. 35-40.

PLAPER, P. G.; CAMANHO, G. L.; SALDIVA, P. H. N. (2001). Avaliação numérica das ondulações das fibras colágeno em ligamento patelar humano (tendão patelar). Revista Brasileira de Ortopedia, v. 36, n. 8, p. 317-321.

PORTER, M. Sports medicine: using heat therapy. Disponível na Internet via http://www. Thehorse.com/0698/sports_medicine.html1. Capturado em dez 2000.

PRIVALOV, P. L. (1982). Stability of proteins: proteins which do not present a single cooperative system. In. Advances in Protein Chemistry. New York Academic, p. 1-104. 
RAIMOND, P. B. H.; TUCKWELL, D. S.; PLUMB, D. A. (2003). A novel and righly

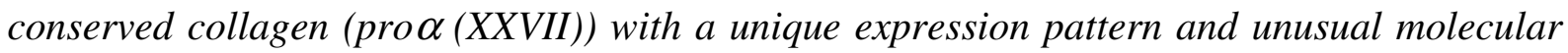
characteristics establishes a new clade within the vertebrate fibrilar collagen family. The Journal of Biological Chemistry, v. 278, n. 33, p. 31067-31076.

RODRIGUES, F. T. (2006). Pele porcina como fonte de matrizes tridimensionais de colágeno. Dissertação de Mestrado, Instituto de Química de São Carlos, Universidade São Paulo.

SACKHEILM, G. I.; LEHMAN, D. D. (2001). Química e Bioquímica para Ciências Biomédicas. 8 ed. São Paulo: Manole.

SANDUSKY, M. D.; SCHULZ, M. M.; McMAHON, P. J.; TIBONE, J. E.; LEE, T. Q. (1999). The effects of laser on joint capsular tissue: An in vivo rabbit. Trans Orthop Res Soc. cap. 24, p. 399.

SCHACHAR, R. A. (1991). Radial thermokeratoplasty. International Ophthalmology Clinics, v. 1, p. 47-57.

SCHAEFER, S. L.; CIARELLI, M. J.; ARNOCZKY, S. P.; ROSS, H. E. (1997). Tissue shrinkage with the holmium:ytrium aluminum garnet laser. A postoperative assessment of tissue length, stiffness, and structure. American Journal of Sports Medicine, v. 6, p. 841-848.

STARKEY, C. (2001). Recursos Terapêuticos em Fisioterapia. 2 ed. São Paulo: Manole.

THABIT, G. (1998). The arthroscopically assited holmium: YAG laser surgery in the shoulder. Operative Thechniques Sports Medicine. cap. 6, p. 131-138.

TILLMAN, L. J.; CUMMINGS, G. S. (1992). Biology mechanisms of connective tissue Mutability. In: CURRIER, D. P.; NELSON, R. M. Dynamics of human biology tissue, Philadelphia: F.A. Davis Company, cap. 1, p.1-41.

UCKO, D. A. (1992). Química Para as Ciências da Saúde. 2 ed. São Paulo: Manole.

VIDAL, B. C. (2003). Image analysis of tendon helical superstructure using interference and polarized light microscopy. Micron, v. 20, n. 20, p. 1-10.

VIDAL, B. C. (1995a). Crimp as Part of a Helical Structure. Life Science Biochemistry, v.318, p. 173-178.

VIDAL, B. C. (1994). Cell and extracelullar matrix interaction: A feed-back theory based on molecular order recognition - adesion events. Revista FCM UNICAMP, v.4, n.11.

VIDAL, B. C.; CARVAlHO, H. F. (1990). Agregational State an Molecular Order of Tendons as a Funtion of Age. Matrix, v.10, p. 48-57

VIDAL, B. C. (1987a). Matrix extracelular. In: VIDAL, B. C.; MELLO, M. L. S. Biologia Celular. Rio de Janeiro e São Paulo: Atheneu, cap.19, p. 273-304. 
VIDAL, B. C. (1987b). Métodos em Biologia Celular. In: VIDAL, B. C.; MELLO, M. L. S. Biologia Celular. Rio de Janeiro e São Paulo: Atheneu, cap.2, p. 5-40.

VILARTA, R.; VIDAL, B. C. (1989). Anisotropic and biomechanical properties of tendons modified by exercise and denervation: Aggregation and macromolecular order in collagen bundles. Matrix, v. 9, p. 55-61.

WALLACE, A. L.; HOLLINSHEAD, R. M.; FRANK, C. B. (2002). Creep behavior of a rabbit model of ligament laxity after electrothermal shrinkage in vivo. American Journal of Sports Medicine, v. 1, p. 98-102.

WALLACE, A. L.; SUTHERLAND, C. A.; MARCHUK, L. L. (1999). Early in vivo effects of electrothermal shrinkage on viscoelastic properties and cellular responses in a model of ligament laxity. Trans Ortho pres Soc. cap. 24, p. 309.

WEIR, C. E. (1949). Rate of shrinkage of tendon collagen-heat, entropy, and free energy of activation of the shrinkage of untreated tendon. Effect of acid, salt, pickle, and tannage on the activation of tendon collagen. J. AM. Leather Chem. Assoc., v. 44, p. 108-140.

WHITAKER, E.; CANHAM, P. B. (1991). Demonstration of quantitative fabric analysis of tendon collagen using two - dimensional polarized light microscopy. Matrix, v.11, p. 56-62.

WORKMAN, T.B. The regeneration process of tissue through various modalities. In: Biology Senior Seminar, 410. Stan Grove, nov. Disponível na Internet via http://www.goshen.edu/Biol410/BSSpapers99/toni.htm. Capturado em dez. 2000.

WRIGHT, N. T.; HUMPHREY, J. D. (2002). Denaturation of collagen via heating: An irreversible rate process. Annu Rev. Biomed Eng, v. 4, p. 109-128.

YOUNG, B; HEATH, J. W. (2001). Histologia Funcional, $4^{\mathrm{o}}$ ed, Rio de Janeiro, gaunabara Koogan, cap. 10, p. 192. 


\section{ANEXOS}

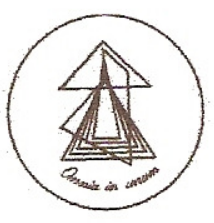

UNIVERSIDADE ESTADUAL PAULISTA "Júlio de Mesquita Filho" Campus de Araçatuba

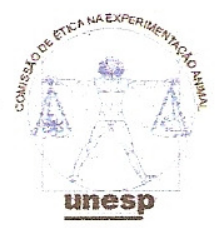

COMISSÃO DE ÉTICA NA EXPERIMENTAC̄̃O ANIMAL

(CEEA)

\section{CERTIICADO}

Certificamos que o Projeto "AVALIACÃO MORFOLÓGICA DO COLÁGENO. APÓS AQUECIMENTO INDUZTDO IN VTVO sob responsabilidade de ANA MARIA DE GUZZI PLEPIS, RUBENS DOS SANTOS ROSA I ANA MARIA PIRES SOUBHIA está de acordo com os Princípios Éticos na Experimentação Animal adotado pelo Colégio Brasileiro de Experimentação Animal (COBEA) e foi aprovado pela CEEA em reunião ordinária de 16 de junho de 2005, de acordo com o protocolo no $78 / 05$.

Araçatuba, 16 de junho de 2005.

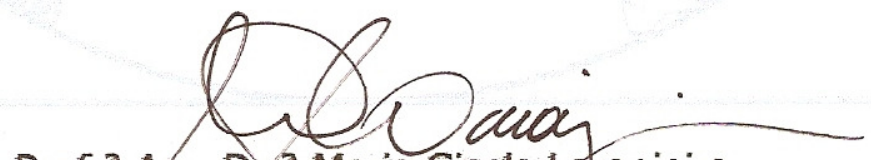

Prof. Ass. DK a Maria Gisela yer ranjeira

Gresidente 